\title{
The Genesis of RLUIPA and Federalism: Evaluating the Creation of a Federal Statutory Right and its Impact on Local Government
}

\author{
Patricia E. Salkin \\ Touro Law Center, psalkin@tourolaw.edu \\ Amy Lavine \\ Albany Law School
}

Follow this and additional works at: https://digitalcommons.tourolaw.edu/scholarlyworks

Part of the Land Use Law Commons, and the Religion Law Commons

\section{Recommended Citation}

40 Urb. Law. 195 (2008)

This Article is brought to you for free and open access by the Faculty Scholarship at Digital Commons @ Touro Law Center. It has been accepted for inclusion in Scholarly Works by an authorized administrator of Digital Commons @ Touro Law Center. For more information, please contact Iross@tourolaw.edu. 


\title{
The Genesis of RLUIPA and
}

Federalism: Evaluating the Creation

of a Federal Statutory Right and

Its Impact on Local Government

\author{
Patricia E. Salkin* \\ Amy Lavine**
}

\section{Introduction}

In 2000, Congress Passed, and President Clinton signed, the Religious Land Use and Institutionalized Persons Act (RLUIPA), ${ }^{1}$ designed to provide protection from discrimination for the exercise of religion by incarcerated individuals and those seeking municipal permits or approvals in order to exercise their religion. This article examines the seven-year history of RLUIPA ${ }^{2}$ and its impact on local governments across the country through an analysis of how the courts have been interpreting statutory ambiguities and creating inconsistent doctrine in an effort to define terms and implement RLUIPA's protections. Whether an appropriate Solomon-like balance can be developed under the Act to clearly recognize compelling governmental interests in protecting the public health, safety, and welfare through land use planning and local environmental controls remains elusive at this point in time and may depend upon the wisdom of the individual federal courts.

Part II of this article explores the uncomfortable relationship of government with religion, and the manner in which this relationship has affected the constitutional interpretations of the Free Exercise Clause of the First Amendment. ${ }^{3}$ Part II also examines the precursor to RLUIPA,

*Patricia E. Salkin is Associate Dean and Director of the Government Law Center of Albany Law School.

**Amy Lavine is a staff attorney at the Government Law Center.

1. 42 U.S.C. $\S 2000 \mathrm{cc}(2006)$.

2. A Westlaw search as of Feb. 15, 2008 for the term "RLUIPA" yielded 954 cases since the statute was enacted, and a search of "RLUIPA" within the same paragraph as "zoning" yielded 158 cases. A similar search in the law review and journal database for RLUIPA and zoning revealed 138 articles.

3. Establishment Clause jurisprudence is indispensable to a thorough understanding of the constitutional attacks that have been directed at RLUIPA, especially in the realm of institutionalized persons. However, what constitutes the establishment of religion and 
the Religious Freedom Restoration Act (RFRA), ${ }^{4}$ enacted by Congress in 1993 and ruled unconstitutional in $1997 .{ }^{5}$ Understanding Congressional motivation for the enactment of RFRA, as well as its constitutional deficiencies, sets the backdrop for the last part of the section, which discusses the Congressional development and enactment of RLUIPA, including why Congress chose land use as a primary focus of religious freedom.

Part III briefly reviews the arguments surrounding the constitutionality of RLUIPA. While not attempting to fully analyze this issue, the discussion is provided since some believe that the statute's constitutionality as it relates to the land use provisions may be vulnerable to further constitutional attack. Part IV discusses the operative provisions of RLUIPA, including both the substantial burden rule and the Act's nondiscrimination provisions. It explores how the courts have interpreted RLUIPA and its ambiguous terms, and discusses how various cases have been decided. The section concludes with a look at how attorneys' fees are addressed in RLUIPA cases. Part V argues why RLUIPA, as drafted, may not necessarily bode well for local governments and their historical use of the police powers to guide community planning and community development. The article concludes with some final comments concerning the propriety of and need for RLUIPA.

\section{Background}

\section{A. Government and Religion: The Development of}

Free Exercise Jurisprudence

The religion clauses of the First Amendment, which simultaneously forbid the government from establishing religion and from prohibiting its free exercise, are looked upon with great respect and admiration by many. ${ }^{6}$ Despite the almost universal support for the concept of protecting religion, religious controversies make their way into the courts in a rich variety of cases, from challenges to the requirements of the social

whether RLUIPA aids government in the establishment of religion is beyond the scope of this article and will not be discussed in much detail.

4. 42 U.S.C. \& $2000 \mathrm{bb}(2006)$.

5. City of Boerne v. Flores, 521 U.S. 507 (1997).

6. In a 2007 poll, $74 \%$ of respondents stated that "the right to practice the religion of your choice" is essential and $57 \%$ found the "right to practice no religion" to be essential. First Amendment Center, State of the First Amendment 2007, 2 (2007), available at http://www.firstamendmentcenter.org/PDF/SOFA2007results. pdf. 
security system ${ }^{7}$ to attacks on the constitutionality of reciting the pledge of allegiance in public schools. ${ }^{8}$ Religious claims have been asserted against drug laws, ${ }^{9}$ laws regulating the educational ${ }^{10}$ and prison systems,${ }^{11}$ prohibitions on animal sacrifice, ${ }^{12}$ military regulations, ${ }^{13}$ and land use and zoning laws. ${ }^{14}$ However, "[j]udges are ill-equipped to examine the breadth and content of an avowed religion[,]"15 and when the courts are asked to demarcate the scope of the religion clauses, they face difficult questions.

Although it is clear that laws may not prohibit or compel specific religious beliefs, it is equally clear that numerous laws affect religious acts and practices, and the government's interests in upholding these laws may be paramount. The Supreme Court has thus long recognized that government may criminalize polygamy and enforce child labor laws, despite the fact that such laws may interfere substantially with religious beliefs. ${ }^{16}$ There are numerous cases that are not as clear cut, however, and weighing the government's interests against religious beliefs is perhaps one of the most difficult tasks that a judge may be asked to face. Even though the judiciary is prohibited from assessing the truth or falsity of religious beliefs, ${ }^{17}$ these cases require courts to determine whether laws burdening religion constitute prohibitions on "free exercise." This inquiry may require, among other things, for the courts to determine whether a particular set of beliefs constitutes a religion, ${ }^{18}$ whether certain

7. See Bowen v. Roy, 476 U.S. 693 (1986); United States v. Lee, 455 U.S. 252 (1982).

8. See W. Va. Bd. of Educ. v. Barnette, 319 U.S. 624 (1943); Minersville Sch. Dist. v. Gobitis, 310 U.S. 586 (1940).

9. See, e.g., Gonzales v. O Centro Espirita Beneficente Uniao de Vegetal, 546 U.S. 418 (2006); Employment Div. v. Smith, 494 U.S. 872 (1990).

10. See, e.g., Locke v. Davey, 540 U.S. 712 (2004); Wisconsin v. Yoder, 406 U.S. 205 (1972); Sch. Dist. of Abington Twp. v. Schempp, 374 U.S. 203 (1963).

11. See, e.g., Cutter v. Wilkinson, 544 U.S. 709 (2005); O'Lone v. Estate of Shabazz, 482 U.S. 342 (1987).

12. See, e.g., Church of Lukumi Babalu Aye v. Hialeah, 508 U.S. 520 (1993).

13. See, e.g., Goldman v. Weinberger, 475 U.S. 503 (1986); United States v. Seeger, 380 U.S. 163 (1965).

14. See, e.g., City of Boerne v. Flores, 521 U.S. 507 (1997).

15. Africa v. Pennsylvania, 662 F.2d 1025, 1031 (3d Cir. 1981).

16. See Prince v. Massachusetts, 321 U.S. 158 (1944) (upholding law prohibiting minors from selling magazines against the child and her guardian's claims that this activity was important to their religious beliefs); Reynolds v. United States, 98 U.S. 145 (1879) (upholding the conviction of a Mormon for practicing polygamy).

17. See, e.g., United States v. Ballard, 322 U.S. 78 (1944) (involving indictments for mail fraud premised on allegations that the Ballards solicited money in support of a fraudulent and contrived religion and holding that the jury could not be asked to consider the truth or falsity of the Ballards' religious doctrines).

18. See, e.g., United States v. Seeger, 380 U.S. 163 (1965) (assessing the requirements for conscientious objector status and rejecting the need to prove belief in a "supreme 
acts constitute religious exercise worthy of constitutional protection, ${ }^{19}$ whether government regulation of such acts can properly be understood as interfering with the exercise of religion,,$^{20}$ and whether governmental interests may be so compelling as to outweigh the need to protect religious freedom. ${ }^{21}$

The evolution of Free Exercise Clause jurisprudence has reflected the tensions that are apparent in conflicts between law and religion. From its first opportunity to assess the meaning and scope of the Free Exercise Clause in $1879^{22}$ until the 1960s, the Supreme Court generally

being"); Africa, 662 F.2d at 1025 (denying religious status to the MOVE organization and categorizing it instead as a "social philosophy"); Malnak v. Yogi, 592 F.2d 197 (3d Cir. 1979) (formulating a test to define religion based on whether the belief system (1) addresses fundamental and ultimate questions relating to imponderable matters; (2) is broad and comprehensive in nature; and (3) is marked by formal and externally identifiable practices); Loney v. Scurr, 474 F. Supp. 1186 (S.D. Iowa 1979) (deeming religious the Church of the New Song, or CONS, a religion started by prison inmates as a "game"); Strayhorn v. Ethical Soc'y of Austin, 110 S.W.3d 458 (Tex. Ct. App. 2003) (holding that the comptroller could not require belief in a higher power as a precondition for extending tax-exempt status to religious organizations).

19. See, e.g., Wisconsin v. Yoder, 406 U.S. 205, 215-16 (1972) (stating that "[a]lthough a determination of what is a 'religious' belief or practice entitled to constitutional protection may present a most delicate question, the very concept of ordered liberty precludes allowing every person to make his own standards on matters of conduct in which society as a whole has important interests"); Beechy v. Cent. Mich. Dist. Health Dep't, 475 F. Supp. 2d 671 (E.D. Mich. 2007) (finding that the type of waste water system used by the Amish is part of their way of life, not their religion).

20. See, e.g., Lyng v. Nw. Indian Cemetery Protective Ass'n, 485 U.S. 439, 450-51 (1988) (stating that "this Court has repeatedly held that indirect coercion or penalties on the free exercise of religion, not just outright prohibitions, are subject to scrutiny under the First Amendment. ... This does not and cannot imply that incidental effects of government programs, which may make it more difficult to practice certain religions but which have no tendency to coerce individuals into acting contrary to their religious beliefs, require government to bring forward a compelling justification for its otherwise lawful actions. The crucial word in the constitutional text is 'prohibit': 'For the Free Exercise Clause is written in terms of what the government cannot do to the individual, not in terms of what the individual can exact from the government." ") (internal citations omitted); Bowen v. Roy, 476 U.S. 693, 706 (1986) (stating that "government regulation that indirectly and incidentally calls for a choice between securing a governmental benefit and adherence to religious beliefs is wholly different from governmental action or legislation that criminalizes religiously inspired activity or inescapably compels conduct that some find objectionable for religious reasons").

21. See, e.g., Gonzales v. O Centro Espirita Beneficente Uniao de Vegetal, 546 U.S. 418 (2006) (finding, under the Religious Freedom Restoration Act, that the federal government's interest in prohibiting a religious group's use of hallucinogenic tea was not compelling); Employment Div. v. Smith, 494 U.S. 872 (1990) (upholding Oregon's refusal to extend a religious exemption to Native Americans from a law prohibiting peyote use); Yoder, 406 U.S. at 205 (holding that the government's interest in compulsory schooling beyond grade eight was not compelling enough to justify refusing an exemption for Amish children).

22. The Supreme Court first examined the meaning of the Free Exercise Clause in Reynolds v. United States, 98 U.S. 145 (1879). The case upheld the conviction of a Mormon for practicing polygamy and the Court famously stated that "[l]aws are made 
took the view that government could regulate religious conduct through generally applicable laws in order to promote public health, safety, and general welfare. Exemptions from such laws for religiously motivated behavior were not considered to be constitutionally required. ${ }^{23}$ Moreover, the cases in which free exercise claims prevailed were often accompanied by free speech or equal protection claims, and the Court tended to resolve cases on these grounds, leaving the exact scope of the Free Exercise Clause unclear. ${ }^{24}$

In 1963, however, the Court announced a new test in Sherbert $v$. Verner. ${ }^{25}$ Adell Sherbert was a Seventh Day Adventist who lost her job because she refused to work on Saturdays, the Sabbath of her faith. ${ }^{26}$ When she applied for unemployment benefits, she was denied them. ${ }^{27}$ The Supreme Court analogized this denial to a "fine imposed ... for her Saturday worship" 28 and held that "no showing merely of a rational relationship to some colorable state interest would suffice [to justify the denial]; in this highly sensitive constitutional area, 'only the gravest

for the government of actions, and while they cannot interfere with mere religious belief and opinions, they may with practices. Suppose one believed that human sacrifices were a necessary part of religious worship, would it be seriously contended that the civil government under which he lived could not interfere to prevent a sacrifice?" Id. at 166.

23. See Church of Lukumi Babalu Aye v. Hialeah, 508 U.S. 520, 569 (1993) (Scalia, J., concurring) (explaining that "Reynolds ... has been read as consistent with the principle that religious conduct may be regulated by general or targeting law only if the conduct "pose[s] some substantial threat to public safety, peace or order." "). For cases typifying this approach, see Cox v. New Hampshire, 312 U.S. 569 (1941) (upholding a permitting scheme for parades and processions as applied to religious groups). See also Braunfeld v. Brown, 366 U.S. 599 (1961) (upholding Sunday closing law against the challenge of Jewish merchants who claimed that it burdened their religious exercise by making it more difficult for them to earn a living while observing Saturday Sabbath); Prince v. Massachusetts, 321 U.S. 158 (1944) (upholding child labor laws as applied to a minor and her guardian who claimed that the child's selling religious magazines was an exercise of her religion); Murdock v. Pennsylvania, 319 U.S. 105, 116 (1943) (stating that "Jehovah's Witnesses are not 'above the law' ... [b]ut the present ordinance is not directed to the problems with which the police power of the state is free to deal"); Frederick Mark Gedicks, The Normalized Free Exercise Clause: Three Abnormalities, 75 IND. L.J. 77, 82-83 (2000) (stating that "[f]or most of its history, the Supreme Court has refused to recognize a free exercise right to exemptions.").

24. See, e.g., W. Va. Bd. of Educ. v. Barnette, 319 U.S. 624 (1943) (striking down requirement that Jehovah's Witness students recite the pledge of allegiance on First and Fourteenth Amendment grounds); Schneider v. State, 308 U.S. 147 (1939) (striking down permit requirement for the distribution of religious pamphlets on free speech and press grounds); Lovell v. City of Griffin, 303 U.S. 444 (1938) (same as Schneider); see also Widmar v. Vincent, 454 U.S. 263 (1981) (assessing the claim that litigants were denied the right to pray on a state university campus under the free speech clause of the First Amendment).

25. 374 U.S. 398 (1963).

26. Id. at 399.

27. Id. at 401 .

28. Id. at 404. 
abuses, endangering paramount interests, give occasion for permissible limitation[..] " ${ }^{29}$ This standard was upheld in Wisconsin v. Yoder, ${ }^{30}$ where the Court held that Wisconsin had no compelling interest sufficient to justify denying the Amish litigants an exemption from the state's compulsory schooling laws. "The essence of all that has been said and written on the subject[,]" the Court explained, "is that only those interests of the highest order ... can overbalance legitimate claims to the free exercise of religion." ${ }^{32}$ The Court continued:

A regulation neutral on its face may, in its application, nonetheless offend the constitutional requirement for government neutrality if it unduly burdens the free exercise of religion. The Court must not ignore the danger that an exception from a general obligation of citizenship on religious grounds may run afoul of the Establishment Clause, but that danger cannot be allowed to prevent any exception no matter how vital it may be to the protection of values promoted by the right of free exercise. ${ }^{33}$

In the years following Sherbert and Yoder, the Court continued to recite the language of the strict scrutiny test, but it is not entirely clear that it applied the compelling interest test with the same vigor that the test requires in other areas of constitutional law. ${ }^{34}$ Religious exemptions were denied under the Sherbert test in cases involving the Fair Labor Standards Act and the social security system, primarily upon the grounds that exemptions would interfere with administration of the programs and raise the possibility of fraudulent claims ${ }^{35}$ - interests that have been described as "relatively weak." ${ }^{6}$ The Court was also willing

29. Id. at 406 (quoting Thomas v. Collins, 323 U.S. 516, 530 (1945)).

30. 406 U.S. 205 (1972).

31. Id. at 221 .

32. Id. at 215 .

33. Id. at 220-21 (internal citations omitted).

34. See William P. Marshall, The Case Against the Constitutionally Compelled Free Exercise Exemption, 40 CASE W. RES. L. REv. 357, 365-66 (1990) (stating that "the Court has been consistent in articulating the test it ostensibly applied in its free exercise decisions. ... Nevertheless, despite the Court's professed allegiance to a fixed constitutional standard, free exercise jurisprudence has never been consistent in result"); Robert W. Tuttle, Regulating Sacred Space: Religious Institutions and Land Use Controls: How Firm a Foundation? Protecting Religious Land Use after Boerne, 68 GEo. WASH. L. Rev. 861, 919 (2000) (stating that "free exercise cases before Smith accepted as compelling a far wider range of governmental interests").

35. See Bowen v. Roy, 476 U.S. 693 (1986) (upholding requirement that parents provide their daughter's social security number in order to obtain state welfare benefits despite their religious objections); Tony and Susan Alamo Found. v. Sec'y of Labor, 471 U.S. 290 (1985) (upholding provisions of the Fair Labor Standards Act relating to minimum wages, overtime and recordkeeping as applied to the religious organization); United States v. Lee, 455 U.S. 252 (1982) (rejecting Amish litigant's religious contention to paying social security taxes because denying such exemptions was justified by the government's interest in uniform application of the social security laws).

36. Marshall, supra note 34, at 368 (quoting Michael W. McConnell, Neutrality Under the Religion Clauses, 81 Nw. U. L. REv. 146, 153 (1986)). 
to accord particular judicial deference to the asserted governmental interests raised in military and prison free exercise cases, ${ }^{37}$ and the Court carved out another exception in Lyng v. Northwest Indian Cemetery Protective Association, ${ }^{38}$ where it determined that the government had a compelling interest in choosing how to dispose of its real property, even though that property was also sacred to Native Americans. ${ }^{39}$ Justice O'Connor, speaking for the Court, explained that:

It is true that this Court has repeatedly held that indirect coercion or penalties on the free exercise of religion, not just outright prohibitions, are subject to scrutiny under the First Amendment. ... This does not and cannot imply that incidental effects of government programs, which may make it more difficult to practice certain religions but which have no tendency to coerce individuals into acting contrary to their religious beliefs, require government to bring forward a compelling justification for its otherwise lawful actions. ${ }^{40}$

It was upon this background of judicial inconsistency that the Court decided the 1990 case of Employment Division v. Smith. ${ }^{41}$ The majority concluded that "the right of free exercise does not relieve an individual of the obligation to comply with a 'valid and neutral law of general applicability[,] "' 42 and thus held that Oregon could criminalize the use of peyote without providing an exemption for religious use by Native Americans ${ }^{43}$ Justice Scalia, writing for the Court, distinguished Sherbert and Yoder separately: Sherbert and its progeny indicated that the strict scrutiny test was appropriate only in contexts lending themselves to "individualized governmental assessment of the reasons for the relevant conduct";44 Yoder, on the other hand, because it implicated the right of parents to direct the upbringing of their children, was an example of a "hybrid" free exercise claim - one involving another constitutional protection - and for that reason it could not be concluded that its strict scrutiny test was required by the Free Exercise Clause alone. ${ }^{45}$ Smith thus sought to harmonize the free exercise jurisprudence by promulgating a straightforward rule: the Free Exercise Clause permits the

37. See, e.g., Goldman v. Weinberger, 475 U.S. 503, 510 (1986) (holding that the air force could refuse to permit a Jewish officer to wear a yarmulke while on the base); O'Lone v. Estate of Shabazz, 482 U.S. 342 (1987) (upholding prison regulations that prohibited Muslim inmates from attending Friday services on the basis that the regulations served the valid penological interests of order and security).

38. 485 U.S. 439 (1988).

39. Id. at 442 .

40. Id. at $450-51$.

41. 494 U.S. 872 (1990).

42. Id. at 879 (internal quotation marks omitted).

43. Id. at 890 .

44. Id. at 884 .

45. Id. at 881-82. 
government to enact otherwise valid, neutral laws of general applicability that incidentally burden religion, and no religious exemption need be provided. Nevertheless, the Court recognized the value of accommodating religious diversity through exemptions to such laws, and it approved of state laws having that effect. ${ }^{46}$

In addition to relying on the inconsistency of its precedents for rejecting the strict scrutiny test, the Smith court also explained that the compelling interest test was unworkable in the sphere of free exercise claims. First and foremost,

[t]o make an individual's obligation to obey [a neutral law of general applicability] contingent upon the law's coincidence with his religious beliefs, except where the State's interest is "compelling"-permitting him, by virtue of his beliefs, "to become a law unto himself" - contradicts both constitutional tradition and common sense. ${ }^{47}$

The majority also recognized that one of the primary flaws of the strict scrutiny test in the field of religious protection was that it required the courts to weigh the burdens imposed on religion against the interests of the government, a task greatly impeded by the Court's often-stated reluctance to judge the centrality of specific beliefs or practices to a person's religion. ${ }^{48}$ "What principle of law or logic[,]" Justice Scalia asked, "can be brought to bear to contradict a believer's assertion that a particular act is 'central' to his personal faith? Judging the centrality of different religious practices is akin to the unacceptable "business of evaluating the relative merits of differing religious claims." "49

The Smith holding was clarified several years later in Church of Lukumi Babalu Aye v. City of Hialeah, ${ }^{50}$ a case involving the application of an ordinance prohibiting the "unnecessary" killing of animals upon adherents of Santeria who performed animal sacrifices as part of their creed. ${ }^{51}$ The Court determined that the ordinance was not neutral and

46. Employment Div., 494 U.S. at 890.

47. Id. at 885 (internal citation omitted). Justice Scalia continued:

The "compelling government interest" requirement seems benign, because it is familiar from other fields. But using it as the standard that must be met before the government may accord different treatment on the basis of race, or before the government may regulate the content of speech, is not remotely comparable to using it for the purpose asserted here. What it produces in those other fields-equality of treatment and an unrestricted flow of contending speech-are constitutional norms; what it would produce here-a private right to ignore generally applicable laws-is a constitutional anomaly.

Id. at 885-86 (internal citations omitted).

48. Id. at 886-87.

49. Id. at 887 (quoting United States v. Lee, 455 U.S. 252, 263 n.2 (1982) (Stevens, J., concurring)).

50. 508 U.S. 520 (1993).

51. Id. at 524-28. 
generally applicable, but rather evidenced religious discrimination. ${ }^{52}$ While prohibiting Santeria sacrifices, it permitted kosher slaughter and allowed hunters and licensed food establishments to butcher their own animals, thereby undermining the law's purported objectives of preventing animal cruelty and ensuring sanitation. ${ }^{53}$ Failing to find that the law was neutral, the Court invoked the strict scrutiny test and invalidated the law:

A law burdening religious practice that is not neutral or not of general application must undergo the most rigorous of scrutiny. To satisfy the commands of the First Amendment, a law restrictive of religious practice must advance "interests of the highest order" and must be narrowly tailored in pursuit of those interests. . . . A law that targets religious conduct for distinctive treatment or advances legitimate governmental interests only against conduct with a religious motivation will survive strict scrutiny only in rare cases. It follows from what we have already said that these ordinances cannot withstand this scrutiny. ${ }^{54}$

The test adopted in Smith and clarified in Lukumi was not well accepted. Some commentators objected to the decision on the ground that the rational basis test was inappropriate, contending that the Court should have adopted intermediate scrutiny standards analogous to those used in fundamental rights and equal protection cases. ${ }^{55} \mathrm{By}$ far the more ubiquitous view, however, and the one more generally accepted among the public, was that the Supreme Court in Smith had done great damage to the constitutional protection of religion. ${ }^{56}$

\section{B. The Religious Freedom Restoration Act of 1993 and City of Boerne v. Flores}

Congress agreed with the public that the Smith decision was wrongly decided and in 1993 it embarked upon its first attempt to supersede the Court's interpretation of the Free Exercise Clause. The Religious Freedom Restoration Act (RFRA), passed by a margin of ninety-seven to three in the Senate, ${ }^{57}$ thus purported to restore the Sherbert and Yoder

52. See id. at 531-32, 534-46.

53. Id. at $538-40,544$.

54. Id. at 546 (internal citations omitted).

55. See, e.g., Gedicks, supra note 23; William P. Marshall, What is the Matter with Equality?: An Assessment of the Equal Treatment of Religion and Nonreligion in First Amendment Jurisprudence, 75 IND. L.J. 193 (2000); Michael W. McConnell, Accommodation of Religion: An Update and a Response to the Critics, 60 GEO. WASH. L. REv. 685 (1992); Tuttle, supra note 34.

56. See, e.g., Linda Greenhouse, Court is Urged to Rehear Case on Ritual Drugs, N.Y. Times, May 11, 1990, at A16 (noting that fifty-five constitutional scholars and a diverse array of religious groups petitioned for a rehearing of the case); Nat Hentoff, Justice Scalia vs. the Free Exercise of Religion, WASH. PosT, May 19, 1990, at A25.

57. See Peter Steinfels, Clinton Signs Law Protecting Religious Practices, N.Y. Times, Nov. 17, 1993, at A18. 
compelling interest test to all cases in which the government substantially burdened religion..$^{58}$

However honorable its intentions, RFRA was fatally flawed. Congress had enacted RFRA exclusively under section 5 of the Fourteenth Amendment, ${ }^{59}$ the Enforcement Clause, which grants it the power to enforce that Amendment and the fundamental rights incorporated through it. Conspicuously absent from the statute were any jurisdictional hooks under the Commerce or Spending Clauses. In the 1997 case City of Boerne v. Flores, ${ }^{60}$ the Supreme Court declared RFRA to be unconstitutional. ${ }^{61}$ After going through an exhaustive history of section 5 , the Court determined that the Enforcement Clause permits Congress to enact remedial and preventative measures, but not definitional legislation. ${ }^{62}$ At oral arguments, it was contended that RFRA was "simply a constitutional amendment in section 5 clothing[,]"63 and the Court seemed to agree. In striking down RFRA as surpassing Congress' authority, the Court explained that

RFRA cannot be considered remedial, preventive legislation, if those terms are to have any meaning. RFRA is so out of proportion to a supposed remedial or preventive object that it cannot be understood as responsive to, or designed to prevent, unconstitutional behavior. It appears, instead, to attempt a substantive change in constitutional protections. Preventive measures prohibiting certain types of laws may be appropriate when there is reason to believe that many of the laws affected by the congressional enactment have a significant likelihood of being unconstitutional.... RFRA is not so confined. Sweeping coverage ensures its intrusion at every level of government, displacing laws and prohibiting official actions of almost every description and regardless of subject matter. RFRA's restrictions apply to every agency and official of the Federal, State, and local Governments. RFRA applies to all federal and state law, statutory or otherwise, whether adopted before or after its enactment. RFRA has no termination date or termination mechanism. Any law is subject to challenge at any time by any individual who alleges a substantial burden on his or her free exercise of religion. The reach and scope of RFRA distinguish it from other measures passed under Congress' enforcement power[.] $]^{64}$

58. In the congressional findings and declaration of purposes, Congress explicitly stated that one of RFRA's purposes was "to restore the compelling interest test as set forth in Sherbert v. Verner, 374 U.S. 398 (1963) and Wisconsin v. Yoder, 406 U.S. 205 (1972) and to guarantee its application in all cases where free exercise of religion is substantially burdened[.]" 42 U.S.C. $\$ 2000 \mathrm{bb}(\mathrm{b})(1)$ (2006).

59. 521 U.S. 507, 516 (1997).

60. Id.

61. Id. at 511 .

62. Id. at 525 .

63. See Transcript of Oral Argument, City of Boerne v. Flores, 521 U.S. 507 (1997) (No. 95-2074), available at http://www.oyez.org/cases/1990-1999/1996/1996_95_ 2074/argument/. (Jeffrey S. Sutton, on behalf of Ohio et al., as amici curiae, supporting the petitioner).

64. City of Boerne, 521 U.S. at 532 (internal citations omitted). 
Central to the Court's holding that RFRA exceeded Congress' enforcement authority was the fact that Congress had made no findings suggesting that the statute was necessary to counteract certain practices of religious discrimination-it was not shown to be a proportional reaction to any existing threat to a constitutional liberty. ${ }^{65}$ The Court thus distinguished RFRA from federal voting rights legislation that prohibited the use of literacy tests; this aspect of the Voting Rights Act, the Court noted, was only applied to "jurisdictions with a history of intentional racial discrimination in voting." ${ }^{66}$ RFRA, in contrast, was "not designed to identify and counteract state laws likely to be unconstitutional because of their treatment of religion." ${ }^{67}$ The Court also indicated that RFRA violated the separation of powers doctrine by usurping the judiciary's role as interpreter of the Constitution, and, citing Marbury $v$. Madison, ${ }^{68}$ it reminded Congress that "the Constitution is preserved best when each part of the government respects ... the proper actions and determinations of the other branches." 69

C. The Religious Liberty Protection Acts and (Finally)

the Religious Land Use and Institutionalized

Persons Act of 2000

Congress was not deterred by City of Boerne, and its next attempt to overrule Smith came in 1998 with the proposal of the Religious Liberty Protection Act. ${ }^{70}$ Unlike RFRA, the Religious Liberty Protection Act relied on Congress' authority under the Commerce and Spending Clauses, as well as its Fourteenth Amendment enforcement authority. ${ }^{71}$ The scope of the new act remained wide, however, covering all instances in which the government substantially burdened a person's religious exercise so long as the actions could be tied to federal spending or interstate commerce. ${ }^{72}$ The bill was reintroduced in $1999,{ }^{73}$ but

65. Id. at 534-35.

66. Id. at 533 .

67. Id. at 534-35.

68. 5 U.S. 137 (1803).

69. City of Boerne, 521 U.S. at 535-36.

70. H.R. 4019, 105th Cong. (2nd Sess. 1998); S. 2148, 105th Cong. (2nd Sess. 1998).

71. See H.R. 4019, 105th Cong. § 2(a) (2nd Sess. 1998); S. 2148, 105th Cong. $\S 2$ (a) (2nd Sess. 1998); see also Religious Liberty Measure, WASH. Post, June 10, 1998 , at A09.

72. See H.R. 4019, 105th Cong. § 2(a) (2nd Sess. 1998); S. 2148, 105th Cong. § 2(a) (2nd Sess. 1998).

73. H.R. 1691, 106th Cong. (1st Sess. 1999). 
never moved passed the Senate Judiciary Committee. ${ }^{74}$ Opposition was due, in part, to the failure of the House to amend the bill to ensure that it would not interfere with other anti-discrimination laws, especially those protecting gays, lesbians, single parents, and people with AIDS. ${ }^{75}$ Criticism was also voiced by the National League of Cities and the National Association of Counties, which were concerned that the bill was "zoning by Congress" and would stymie efforts to protect residential neighborhoods from the traffic and noise caused by "mega-churches." 76 One of the bill's sponsors withdrew his support, explaining that "[t]his bill is supposed to be a shield to protect rights, but some people want to use it as a sword to attack rights[.]"77

While the Religious Liberty Protection Act of 1999 was languishing in the Senate Judiciary Committee, another RFRA-replacement was working its way through Congress. ${ }^{78}$ The Religious Land Use and Institutionalized Persons Act of 2000 (RLUIPA) limited its protection of religion to instances where the government imposes substantial burdens on religion through land use regulations or laws relating to institutionalized persons (a group composed primarily of prisoners and persons housed in state medical institutions). Like the Religious Liberty Protection Acts, RLUIPA was enacted through Congress' authority under the Commerce and Spending Clauses, as well as section 5 of the Fourteenth Amendment.

Despite opposition to the Religious Liberty Protection Acts from national municipal organizations, RLUIPA was passed quickly and unanimously. ${ }^{79}$ Concerns that the Act would interfere with local governments' ability to zone and plan were drowned out by extensive testimony describing how religious organizations had been discriminated against by municipalities. ${ }^{80}$ These "parades of horribles" were likely made in

74. H.R. 1691, 106th Cong. (1st Sess. 1999) (as passed by House and referred to Senate Committee on Judiciary, Nov. 19, 1999).

75. See David G. Savage \& Richard Simon, Religious Rights: The Devil is in the Details, L.A. Times, Aug. 1, 1999, at A1.

76. Id.

77. Michael Grunwald \& Hanna Rosin, House Passes Religious Rights Bill; Legislation Curbing Government's Right to Interfere Prevails 306-118, WASH. Post, July 16, 1999, at A01 (quoting Rep. Nadler).

78. See John Dinan, Congressional Responses to the Rehnquist Court's Federalism Decisions, 32 Publius 3 (2002).

79. See S. 2869, 106th Cong. (2d Sess. 2000) (enacted) (introduced in Senate on July 13, 2000 and signed by President Clinton on Sept. 22, 2000).

80. See, e.g., 146 CoNG. REC. E. 1564 (2000) (statement by Rep. Hyde on the Religious Land Use and Institutionalized Persons Act of 2000); see also Tuttle, supra note 34 (listing Congressional testimony relating to the religious bills that emphasized discrimination in the land use field). 
response to City of Boerne, which had suggested that Congress could not rely on its section 5 authority without first determining that there existed wrongs requiring enforcement. Nevertheless, for as discomfiting as these examples of religious discrimination were, Congress was not presented with any evidence as to how common zoning abuse actually was, nor were groups representing homeowners or municipalities given an opportunity to testify. ${ }^{81}$ As a result, members of Congress did not consider many of the negative effects that the law was likely to cause. RLUIPA's sponsors, however, were not totally unaware of the problems that the law might cause to local governments. In the Joint Statement of Senators Hatch and Kennedy, the bill's sponsors explained:

This Act does not provide religious institutions with immunity from land use regulation, nor does it relieve religious institutions from applying for variances, special permits or exceptions, hardship approval, or other relief provisions in land use regulations, where available without discrimination or unfair delay. ${ }^{82}$

A question often asked about RLUIPA, given its long history and odd formulation, is why it was limited to cover only land use and institutionalized persons, a pair not usually considered together. Why, for example, did it not also cover unemployment benefits cases, the exact problem involved in Sherbert and Smith that began the whole debate about the meaning of the right to free exercise of one's religion? Given the Court's jurisprudence, one might have also expected Congress to extend heightened religious protections to public school students and members of the military as well.

RLUIPA's legislative history does not directly answer these questions, but it does offer clues. The Court had effectively admonished Congress in City of Boerne for trying to use RFRA to solve a problem

81. Professor Marci Hamilton, who argued the Boerne case before the Supreme Court on behalf of the city, has repeatedly emphasized the shortcomings of the legislative process. As she described:

$[\mathrm{N}]$ o land use official or neighbor to a religious building was ever permitted to testify. ... [B]oth political parties knelt before the altar of religious lobbyists. They refused to ask the hard questions about RLUIPA, even after repeated requests to testify from groups like the National League of Cities. ... As a result, the hearing record relies on anecdotal accounts of discrimination against religious buildings in land use.... It also fails to make a substantial inquiry into the negative secondary effects religious buildings and other religious institutions can rain down on their residential neighbors.

Marci Hamilton, Struggling with Churches as Neighbors: Land Use Conflicts between Religious Institutions and Those Who Reside Nearby, FindLaw, Jan. 17, 2002, http:// writ.news.findlaw.com/hamilton/20020117.html (last visited Mar. 1, 2008).

82. 146 Cong. REC. S7774 (2000) (joint statement of Sen. Hatch, Sen. Kennedy, and Sen. Reid on the Religious Land Use and Institutionalized Persons Act of 2000). 
that it had not shown to actually exist. ${ }^{83}$ The Court did give clues, however, that section 5 would permit Congress to enact provisions similar to RFRA so long as they were proportional and directed only to limited areas in which religious discrimination had proven to be a problem. ${ }^{84}$ Since "[l] and use proved to be one of the few areas (if not the only area) in which supporters of free exercise exemptions could produce such evidence[,]"85 the bill's proponents put their energy into demonstrating that zoning laws were often used in a discriminatory manner. This was not especially difficult; citizens who oppose land use decisions often make emotional, and sometimes discriminatory, remarks at public hearings.

RLUIPA, clearly, was also a compromise between supporters of broader religious protection and others who believed that more general legislation would have endangered other civil rights. ${ }^{86}$ Moreover, Smith had left Sherbert intact insofar as it applied the strict scrutiny test to unemployment benefits cases, making legislation overruling Smith in this area unnecessary. ${ }^{87}$ The result of these factors was an unusually specialized law, the awkward result of a tug of war between the Supreme Court, Congress, and the religious lobby. ${ }^{88}$

\section{RLUIPA's Constitutionality}

\section{A. Cutter v. Wilkinson and the Establishment Clause}

Given the decision in City of Boerne, which intimated that the Supreme Court viewed RFRA as an attack upon the Court's exclusive role to "say what the law is," it is not surprising that RLUIPA's constitutionality was doubted from its inception. ${ }^{89}$ RLUIPA, however, did not rely

83. See discussion supra Part II.B.

84. Professor Hamilton conceded so much in oral arguments before the Court. As she explained: "[i]f Congress had evidence that there were instances where there was discrimination in a particular arena with respect to particular types of religions, Congress certainly could go ahead and [enact preventative legislation under section 5]." Transcript of Oral Argument, City of Boerne v. Flores, 521 U.S. 507 (1997) (No. 95-2074), available at http://www.oyez.org/cases/1990-1999/1996/1996_95_2074/argument/.

85. Tuttle, supra note 34 , at 863.

86. See id.; 146 CoNG. REC. S7774 (2000) (statement of Sen. Hatch).

87. See Employment Div. v. Smith, 494 U.S. 872, 884 (1990); see also Tuttle, supra note 34 , at 887 .

88. For information on the role of religious lobbies in the Smith aftermath, see Bradley P. Jacob, Free Exercise in the "Lobbying Nineties," 84 NeB. L. REv. 795 (2006).

89. See, e.g., 146 CONG. REC. S7991 (2000). Senator Thurmond, an unlikely opponent to a religious protection law, noted that

the Religious Land Use and Institutionalized Persons Act . . . is essentially an attempt to change the way the courts interpret the Free Exercise Clause of the Constitution 
exclusively on the authority granted to Congress by section 5 of the Fourteenth Amendment; rather, it included Commerce Clause and Spending Clause jurisdictional hooks. Moreover, Congress had taken the Supreme Court's hints that it should compile findings on the need for the legislation and limit its scope to something less than a universal and retroactive law.

When RLUIPA finally reached the Supreme Court in the 2005 case of Cutter v. Wilkinson,,$^{90}$ many of the fears that the Act would be found to be unconstitutional were allayed. Cutter and his co-petitioners were prisoners and adherents of nonmainstream faiths, and their claims centered on allegations that prison officials had denied them access to religious literature, group worship activities, and various ceremonial items. ${ }^{91}$ The responsive claim, that RLUIPA was unconstitutional, was based primarily on the contention that it violated the Establishment Clause by improperly advancing religion over irreligion. ${ }^{92}$ The Sixth Circuit had agreed with this argument, finding that

the primary effect of RLUIPA is not simply to accommodate the exercise of religion by individual prisoners, but to advance religion generally by giving religious prisoners rights superior to those of nonreligious prisoners. . . RLUIPA also has the effect of encouraging prisoners to become religious in order to enjoy greater rights. ${ }^{93}$

Recognizing, however, that "there is room for play in the joints" between the religion clauses, the Supreme Court rejected the Establishment Clause claim and upheld the statute as a "permissible legislative accommodation of religion." 94

Cutter did not address RLUIPA's land use provisions, leaving open the possibility that the Act's land use component might yet be struck down. The lower federal courts, though, seem to have come to the consensus that the reasons given by the Court for upholding the institutionalized persons aspect of the Act apply equally to the section dealing with land use. ${ }^{95}$ While this article will not address Establishment Clause

regarding prisons and land use regulations throughout the Nation. ... Just as the Religious Liberty Protection Act has been held unconstitutional as applied to the states ... there are legitimate issues regarding whether [RLUIPA] is constitutional. Id.

90. 544 U.S. 709 (2005).

91. Id. at 712-13.

92. Id. at 717-18.

93. Cutter v. Wilkinson, 349 F.3d 257, 266 (2003), rev'd, 544 U.S. 709 (2005).

94. Id. at 719-20 (internal citations omitted).

95. See, e.g., Westchester Day Sch. v. Vill. of Mamaroneck, 504 F.3d 338, 355-56

(2d Cir. 2007); Midrash Sephardi, Inc. v. Town of Surfside, 366 F.3d 1214, 1240-42 (11th Cir. 2004); Westchester Day Sch. v. Vill. of Mamaroneck, 417 F. Supp. 2d 477, 557 (S.D.N.Y. 2006); Castle Hills First Baptist Church v. City of Castle Hills, No. 
concerns, it bears noting that Cutter has not gone without criticism, and a few commentators believe that RLUIPA's land use provisions may yet be found to be impermissible establishments of religion. ${ }^{96}$

\section{B. Federalism}

Great weight has been placed on Cutter's finding that RLUIPA is constitutional, as is proper, but due to the stance of the case, the Supreme Court did not address RLUIPA's other possible constitutional infirmities. ${ }^{97}$ Left to another day were questions raised by City of Boernequestions concerning federalism, the separation of powers, and Congress' power under section 5 and the Commerce and Spending Clauses. These issues are closely related and they merit discussion.

\section{FEDERALISM AND THE TENTH AMENDMENT}

In looking to the federalism problem, the first question is whether Congress had some authority to enact RLUIPA. If it did not have any power to enact such legislation, then RLUIPA would violate the Tenth Amendment, which states that "[t]he powers not delegated to the United States by the Constitution, nor prohibited by it to the States, are reserved to the States respectively, or to the people." ${ }^{98}$ City of Boerne was decided primarily on the basis that RFRA was ultra vires, beyond Congress' remedial section 5 powers. To address this problem, Congress did three things: it narrowed the scope of its religious protection; it made findings demonstrating why RLUIPA was necessary; and it added Commerce and Spending Clause jurisdictional hooks. ${ }^{99}$

RLUIPA makes clear that its substantial burden test applies only when one of its jurisdictional hooks is satisfied. To meet this requirement, a claimant must show that the substantial burden was imposed in a program or activity receiving federal funding, that the burden (or its removal) would affect interstate commerce, or that the burden re-

SA-01-CA-1149-RF, 2004 WL 546792, at *18 (W.D. Tex. March 17, 2004); United States v. Maui County, 298 F. Supp. 2d 1010, 1014 (D. Haw. 2003).

96. See, e.g., Morgan F. Johnson, Comment, Heaven Help Us: The Religious Land Use and Institutionalized Persons Act's Prisoners Provisions in the Aftermath of the Supreme Court's Decision in Cutter v. Wilkinson, 14 AM. U.J. GENDER Soc. PoL'y \& L. 585 (2006) (arguing that Cutter was wrongly decided); see also Richard C. Schragger, The Role of the Local in the Doctrine and Discourse of Religious Liberty, 117 HARV. L. REv. 1810, 1846 (2004) (noting that "[i]n terms of the sheer breadth of the regulatory privilege, the favoring of religion over nonreligion raises significant Establishment Clause concerns").

97. See Cutter v. Wilkinson, 544 U.S. 709, 719 n.7 (2005).

98. U.S. Const. amend. X.

99. See supra II.C. 
sulted from the application of land use regulations that involved "formal or informal procedures or practices that permit the government to make[] individualized assessments of the proposed uses for the property involved." 100

\section{a. The Enforcement Clause}

The Supreme Court in City of Boerne indicated that Congress did have the authority under section 5 to enact legislation protecting religious freedoms - it just had to do so in a more precise manner than RFRA, which affected all federal, state, and local laws, whether statutory or regulatory. RLUIPA, however, was formulated with the knowledge that in order to be a valid exercise of the enforcement power, "[t]here must be a congruence and proportionality between the injury to be prevented or remedied and the means adopted to that end." ${ }^{101}$ RLUIPA, as a much narrower statute than RFRA, would seem to fall within the scope of these enforcement powers, for although RLUIPA may be overbroad in application, "[1]egislation which deters or remedies constitutional violations can fall within the sweep of Congress' enforcement power even if in the process it prohibits conduct which is not itself unconstitutional. . ."'102 Moreover, the Supreme Court has acknowledged that "[i]t is for Congress in the first instance to 'determine whether and what legislation is needed to secure the guarantees of the Fourteenth Amendment,' and its conclusions are entitled to much deference." 103 Of the courts to have discussed RLUIPA's relation to the Fourteenth Amendment's enforcement provision, most have found it to be adequate. ${ }^{104}$ The lower federal and state courts are likely to continue extending deference to Congress' determination that RLUIPA was necessary to prevent "often covert" 105 religious discrimination by land use authorities.

100. 42 U.S.C. $\S 2000 \mathrm{cc}(\mathrm{a})(2)(\mathrm{c})(2006)$.

101. City of Boerne v. Flores, 521 U.S. 507, 520 (1997).

102. Id. at 518.

103. Id. at 536 (quoting Katzenbach v. Morgan, 348 U.S. 641, 651 (1966)).

104. See, e.g., Lighthouse Cmty. Church of God v. City of Southfield, No. 05-40220, 2007 WL 30280 (E.D. Mich. Jan. 3, 2007); Church of the Hills v. Twp. of Bedminster, No. 05-3332, 2006 WL 462674 (D.N.J. Feb. 24, 2006); Congregation Kol Ami v. Abington Twp., No. 01-1919, 2004 WL 1837037 (E.D. Pa. Aug. 17, 2004); Castle Hills First Baptist Church v. City of Castle Hills, No. SA-01-CA-1149-RF, 2004 WL 546792 (W.D. Tex. Mar. 17, 2004); United States v. Maui County, 298 F. Supp. 2d 1010, 1016 (D. Haw. 2003); Life Teen, Inc. v. Yavapai County, No. 01-1490, 2003 U.S. Dist. LEXIS 24363 (D. Ariz. Mar. 26, 2003). For a case espousing the opposite view-that RLUIPA is not a proper exercise of the enforcement power-see Elsinore Christian Ctr. v. City of Lake Elsinore, 270 F. Supp. 2d 1163, 1176-82 (C.D. Cal. 2003), overruled by Elsinore Christian Ctr. v. City of Lake Elsinore, 197 F. App'x 718 (9th Cir. 2006).

105. 146 CONG. REC. S7775 (2000). 


\section{b. The Commerce and Spending Clauses}

Regardless of whether RLUIPA is determined to be a valid use of Congress' enforcement authority, RLUIPA contains two other jurisdictional hooks: the Commerce and Spending Clauses. Congress' power under both clauses has long been understood to be broad, and RLUIPA explicitly requires the interstate commerce or federal spending nexus to be proven in each case. ${ }^{106}$

The Spending Clause has been much more important to RLUIPA prisoner cases than it has been to land use cases, where the Commerce Clause is generally more relevant. Courts evaluating prisoners' claims under RLUIPA have generally approved of the Spending Clause jurisdictional element. ${ }^{107}$

Even if RLUIPA is a questionable use of Congress' spending powers, an argument being pushed by a few commentators, ${ }^{108}$ it seems unlikely that the Commerce Clause would be found to be inapplicable. It is true that the Court restricted the breadth of the Commerce Clause in United States v. Lopez ${ }^{109}$ and United States v. Morrison, ${ }^{110}$ holding that the Commerce Clause may only be used to regulate economic activity ${ }^{11}$ that uses channels or instrumentalities of interstate commerce or that has a substantial relation to interstate commerce. ${ }^{12}$ RLUIPA's land use provisions, however, would seem to fit within at least one of these categories, and, unlike Lopez and Morrison, the Commerce Clause nexus included in RLUIPA must be proven in each case for the Act to apply. ${ }^{113}$ The bill's sponsors explained that

[t]he jurisdictional element in this bill is that, in each case, the burden on religious exercise, or removal of that burden, will affect interstate commerce. This will most commonly be proved by showing that the burden prevents a specific economic transaction in commerce, such as a construction project, purchase or rental of a building, or an interstate shipment of religious goods. The aggregate of all such transactions is obviously substantial. . . ${ }^{114}$

106. 42 U.S.C. $\S \S 2000 \mathrm{cc}(\mathrm{a})(2), 2000 \mathrm{cc}-1$ (b) (2006).

107. See, e.g., Madison v. Virginia, 474 F.3d 118, 124-29 (4th Cir. 2006); Cutter v. Wilkinson, 423 F.3d 579, 584-90 (6th Cir. 2005); Benning v. Georgia, 391 F.3d 1299, 1305-08 (11th Cir. 2004); Charles v. Verhagen, 348 F.3d 601, 606-11 (7th Cir. 2003); Mayweathers v. Newland, 314 F.3d 1062, 1066-70 (9th Cir. 2002).

108. See, e.g., Benjamin D. Cramer, Comment, Can Congress Buy RLUIPA's Way to Constitutional Salvation?, 55 CASE W. RES. L. REv. 1073 (2005).

109. 514 U.S. $549(1995)$.

110. 529 U.S. $598(2000)$.

111. Id. at 613 (finding gender-motivated violence not to be economic activity).

112. Lopez, 514 U.S. at 558-59.

113. 42 U.S.C. $\$ 2000 \mathrm{cc}(\mathrm{a})(2)(B)$ (2006) (RLUIPA only applies in cases in which the substantial burden, or its removal, would affect interstate commerce. Conversely, a case in which the substantial burden, or its removal, would not affect interstate commerce, RLUIPA would not apply.).

114. 146 Cong. REC. S7775 (2000) (Joint Statement of Senator Hatch and Senator Kennedy on the Religious Land Use and Institutionalized Persons Act of 2000). 
Most of the courts to have reached the question have agreed that RLUIPA's Commerce Clause hook is constitutional. ${ }^{115}$ Although some commentators have expressed doubts that Lopez and Morrison support such broad Commerce Clause powers as those implicated in RLUIPA, ${ }^{116}$ the Supreme Court's 2005 decision of Gonzales v. Raich ${ }^{117}$ reaffirmed the expansive scope of the Commerce Clause and seems to provide persuasive support for this aspect of RLUIPA's constitutionality. ${ }^{118}$

\section{OTHER FEDERALISM ISSUES}

If it is assumed, then-and it is the safer assumption-that RLUIPA is valid under section 5 of the Fourteenth Amendment, the Commerce Clause, or the Spending Clause, then the argument that RLUIPA violates principles of federalism must be based on more than a facial reading of the Tenth Amendment. The Commerce Clause, Spending Clause,

115. See, e.g., Westchester Day Sch. v. Vill. of Mamaroneck, 504 F.3d 338, 354 (2d Cir. 2007) (noting that "where the relevant jurisdictional element is satisfied, RLUIPA constitutes a valid exercise of congressional power under the Commerce Clause. ... In this case, the district court found the jurisdictional element satisfied by evidence that the construction of Gordon Hall, a 44,000 square foot building with an estimated cost of $\$ 9$ million, will affect interstate commerce. We identify no error in this conclusion. As we have recognized, the evidence need only demonstrate a minimal effect on commerce to satisfy the jurisdictional element"); Church of the Hills v. Twp. of Bedminster, No. 05-3332, 2006 WL 462674 (D.N.J. Feb. 24, 2006); Congregation Kol Ami v. Abington Twp., No. 01-1919, 2004 WL 1837037 (E.D. Pa. Aug. 17, 2004); Castle Hills First Baptist Church v. City of Castle Hills, No. SA-01-CA-1149-RF, 2004 WL 546792 (W.D. Tex. Mar. 17, 2004); Life Teen, Inc. v. Yavapai County, No. CIV 011490 PCT RCB, 2003 U.S. Dist. LEXIS 24363 (D. Ariz. Mar. 26, 2003); United States v. Maui County, 298 F. Supp. 2d 1010, 1015 (D. Haw. 2003); Hale O Kaula Church v. Maui Planning Commission, 229 F. Supp. 2d 1056, 1071-72 (D. Haw. 2002); Freedom Baptist Church v. Twp. of Middletown, 204 F. Supp. 2d 857, 867 (E.D. Pa. 2002) (stating that "the mere fact that zoning is traditionally a local matter does answer Congress' undoubtedly broad authority ... to regulate economic activity even when it is primarily intrastate in nature. ... Thus, insofar as state or local authorities 'substantially burden' the economic activity of religious organizations, Congress has ample authority to act under the Commerce Clause"). The cases that have held RLUIPA to be an invalid exercise of power under the Commerce Clause are rare and have without exception been overruled. See, e.g., Elsinore Christian Ctr. v. City of Lake Elsinore, 197 F. App'x 718 (9th Cir. 2006) (reversing earlier decision that RLUIPA was unconstitutional) rev'g 270 F. Supp. 2d 1163 (C.D. Cal. 2003).

116. See, e.g., Lara A. Berwanger, Note, White Knight?: Can the Commerce Clause Save the Religious Land Use and Institutionalized Persons Act?, 72 FORDHAM L. REv. 2355 (2004); Evan M. Shapiro, Notes \& Comments, The Religious Land Use and Institutionalized Persons Act: An Analysis Under the Commerce Clause, 76 W ASH. L. REv. 1255 (2001).

117. 545 U.S. 1 (2005).

118. In Raich, the Court held that Congress could regulate the activity of growing marijuana at home for purely personal use under the aggregation doctrine first announced in Wickard v. Filburn, 317 U.S. 111 (1942). If Congress has the authority to regulate the purely intrastate activity of growing marijuana for personal use-a substance that does not have a legal commercial existence-it would seem, a fortiori, that Congress may regulate aspects of religious land use that, in their aggregate effect, have a substantial effect on interstate commerce. 
and Fourteenth Amendment directly confer authority upon the federal government to regulate activities once considered to be reserved to the states, ${ }^{119}$ and thus a finding that Congress acted within its authority in enacting RLUIPA would seem to preclude a federalism challenge. ${ }^{120}$ The only other modern basis for invalidating a federal law under the Tenth Amendment occurs when the states are compelled "to enact or enforce a federal regulatory program." 121 RLUIPA simply cannot be said to do this; while it prohibits land use regulations that unjustifiably burden religion, it "leaves individual states free to eliminate the discrimination in any way they choose[.]"122

The federalism argument against RLUIPA has been formulated in other ways, however. It has been argued, for example, that there is a "federalist aspect" of the Establishment Clause that gives plenary authority to the states to regulate religion within the gray zone between the Free Exercise and Establishment Clauses. ${ }^{123}$ In a broader formulation, this argument contends that "local government-and more generally the decentralization of power-is a robust structural component of

119. See, e.g., South Dakota v. Dole, 483 U.S. 203, 210 (1987) (finding that "a perceived Tenth Amendment limitation on congressional regulation of state affairs [does] not comitantly limit the range of conditions legitimately placed on federal grants [under the Spending Clause]."); Katzenbach v. Morgan, 384 U.S. 641 (1966) (upholding section 5 legislation after it was held to violate the Tenth Amendment); Wickard v. Filburn, 317 U.S. 111 (1942) (holding that the Commerce Clause provides Congress with plenary authority to regulate all activity affecting interstate commerce, even if it is wholly intrastate in nature).

120. See, e.g., Midrash Sephardi, Inc. v. Town of Surfside, 366 F.3d 1214, 1242 (11 th Cir. 2004) (stating that "[a]lthough RLUIPA intrudes to some degree on local land use decisions, RLUIPA does not violate principles of federalism if it is otherwise grounded in the Constitution").

121. Printz v. United States, 521 U.S. 898, 935 (1997); see also New York v. United States, 505 U.S. 144 (1992).

122. Midrash Sephardi, 366 F.3d at 1242.

123. See Brief for Respondents at 25-28, Cutter v. Wilkinson, 423 F.3d 579 (6th Cir. 2005) (No. 03-9877); see also Matthew Gaus, Note, Locke v. Davey: Discretion, Discrimination, and the New Free Exercise, 54 KAN. L. REv. 553, 584-85 (2006) (stating that "by creating the zone of discretion in the religious clauses, the Locke [v. Davey] court gave at least implied legitimacy to the notion that, within certain limits, the federal government is not authorized to interfere with state religious policy"). The argument is drawn from textual and historical arguments:

the text is plain: "Congress shall make no law respecting an establishment of religion." That meant, pre-incorporation, not only that Congress could not declare a national religion, but that Congress could not interfere with (i.e. make a law respecting) State choices to establish official religions. Of course, States can no longer establish preferred churches, but Congress is as unable as ever to contravene constitutionally permissible State choices regarding religious policy.

Brief for Respondents at 26, Cutter, 423 F.3d 579 (No. 03-9877). 
religious liberty." 124 The Cutter majority did not address this argument, but Justice Thomas did in his concurring opinion. He acknowledged the existence of this federalist aspect of the religion clauses, but rejected the contention that it undercut RLUIPA's validity. "The Clause[,]" he explained, "prohibits Congress from enacting legislation 'respecting an establishment of religion;' it does not prohibit Congress from enacting legislation 'respecting religion' or 'taking cognizance of religion." "125

While this "federalist aspect" argument may be somewhat esoteric, there is a much more understandable federalism concern, namely, that the federal government has no place in the regulation of land use-an inherently local endeavor tied to characteristics of the land and the needs of the community. ${ }^{126}$ The courts have not looked fondly upon this argument, however, generally explaining that RLUIPA does not impermissibly intrude upon local governments' authority to regulate land use. Rather, according to the courts to have reached the question, "[l]and use regulation is left to the States and local governments ... they are simply prohibited from imposing substantial burdens on religious exercise in the process." 27 In this sense, "RLUIPA is not federal zoning of [local] land; it is federal enforcement of federal rights." ${ }^{128}$ Framing the problem as such, the courts have had difficulty distinguishing RLUIPA from other federal statutes that intrude upon local land use decisions, such as the Fair Housing Act, the Americans with Disabilities Act and the Telecommunications Act. ${ }^{129}$ Yet, as will be explained below, RLUIPA

124. Richard C. Schragger, The Role of the Local in the Doctrine and Discourse of Religious Liberty, 117 HARV. L. REV. 1810, 1815 (2004). Some proponents of this view believe that the Establishment Clause should not have been incorporated at all. See generally Stephen K. Green, Religion Clause Federalism: State Flexibility Over Religious Matters and the "One-Way Ratchet," 56 EMORY L.J. 107 (2006) (discussing the implications of a federalist or decentralized approach to the religion clauses); Ira C. Lupu \& Robert W. Tuttle, Federalism and Faith, 56 EMORY L.J. 19 (2006) (discussing the interplay of the establishment and free exercise clauses and the effect of their incorporation on the development of state and local religion policies).

125. Cutter v. Wilkinson, 544 U.S. 709, 728 (2005) (Thomas, J., concurring) (emphasis in original).

126. See Marci A. Hamilton, Federalism in the Rehnquist Court, Ass'N OF Am. L. ScHS., http://www.aals.org/profdev/constitutional/hamilton.html (last visited Feb. 25, 2008).

127. Life Teen, Inc. v. Yavapai County, No. CIV 01-1490 PCT RCB, 2003 U.S. Dist. LEXIS 24363, at *49 (D. Ariz. Mar. 26, 2003); see also Midrash Sephardi, Inc. v. Town of Surfside, 366 F.3d 1214, 1242 (11th Cir. 2004) (explaining that "[a]lthough RLUIPA intrudes to some degree on local land use decisions, RLUIPA does not violate principles of federalism if it is otherwise grounded in the Constitution").

128. United States v. Maui County, 298 F. Supp. 2d 1010, 1015 (D. Haw. 2003).

129. See, e.g., id.; Freedom Baptist Church v. Twp. of Middletown, 204 F. Supp. 2d 857,867 (E.D. Pa. 2002). 
has had an enormous impact on local governments and contentions that Congress should not have usurped local land use laws with RLUIPA are persuasive, even if they are not legal in nature.

\section{Separation of Powers}

RLUIPA's federalism issues are closely related to concerns about the separation of powers; whereas the federalist position argues that Congress overstepped its bounds by intruding upon the states' domain, the claim that RLUIPA violates principles of the separation of powers posits that Congress usurped the judicial role of interpreting the constitution. Congress' response to the separation of powers concerns raised in City of Boerne was to limit the scope of RLUIPA and to indicate that it was not overruling Supreme Court precedent at all, but rather codifying it. ${ }^{130}$ The contention that Congress merely codified Supreme Court precedent in RLUIPA, however, is hard to reconcile when viewed in light of the Smith decision to RLUIPA progression. It has posed problems for courts interpreting RLUIPA because the courts have had to choose whether to abide by Free Exercise jurisprudence, or to follow Congress' likely intent to expand religious protection. As one court explained:

To give such broad meaning to [RLUIPA] ... would be in direct conflict with the holding of Smith that generally applicable laws that are intended to protect the public health and safety constitutionally may be applied to religious conduct without being justified by a compelling government interest, regardless of the burden that the laws impose on such conduct.... Thus, interpreting the substantial burden provision of RLUIPA as creating a significantly broader right than that guaranteed by the free exercise clause would render the statute constitutionally suspect under Boerne. On the other hand, interpreting the provision as creating a right with precisely the same scope and contours as that guaranteed by the free exercise clause would ignore the statute's express terms and effectively render it superfluous. ${ }^{131}$

Despite the limited scope of RLUIPA as compared to RFRA, some separation of powers arguments have been raised. ${ }^{132}$ Among these arguments, the most common is that RLUIPA, in essence, displaced the Free Exercise Clause in land use and prison cases, and that Congress may not create new constitutional standards, regardless of their limited

130. See, e.g., 146 CoNG. Rec. S7775 (2000).

131. Cambodian Buddhist Soc'y v. Planning \& Zoning Comm'n of Newtown, No. 17690, 2008 WL 248053, at *14 (Conn. Feb. 12, 2008).

132. See Elsinore Christian Ctr. v. City of Lake Elsinore, 270 F. Supp. 2d 1163, 117683 (C.D. Cal. 2003) (holding RLUIPA to be unconstitutional on federalism grounds but drawing on separation of powers doctrine as well), overruled by Elsinore Christian $\mathrm{Ctr}$. v. City of Lake Elsinore, 197 F. App'x 718 (9th Cir. 2006). For a thorough discussion of separation of powers arguments in relation to RLUIPA and RFRA, see Michael Paisner, Note, Boerne Supremacy: Congressional Responses to City of Boerne v. Flores and the Scope of Congress' Article I Powers, 105 Colum. L. REv. 537 (2005). 
application. ${ }^{133}$ The most obvious challenge to this argument, though, is that RLUIPA was not intended to, and has not in practice, replaced constitutional free exercise standards; rather, numerous RLUIPA claims are brought in tandem with free exercise claims. ${ }^{134}$

It has also been argued that RLUIPA impermissibly expanded upon the constitutional meaning of the Free Exercise Clause by defining the term "religious exercise" to include "[t]he use, building, or conversion of real property for the purpose of religious exercise." 135 The Connecticut Supreme Court in Cambodian Buddhist Society v. Planning \& Zoning Commission of Newtown ${ }^{136}$ pointed out that, in this regard, RLUIPA conflicts with "existing [F]irst [A]mendment jurisprudence, which holds that building and owning a church ... do not [automatically] constitute the exercise of religion within the meaning of the [F]ree [E]xercise [C]lause." 137 The court attempted to harmonize RLUIPA with Smith and other free exercise jurisprudence by concluding that "RLUIPA's substantial burden provision applies only when the government has made an "individualized [assessment] of the proposed [use]" " and is therefore not part of a neutral and generally applicable law. ${ }^{138}$ This interpretation might stand if it was based on the doctrine of separation of powers, but the court did not clarify its basis for reaching this conclusion. ${ }^{139}$

133. See id. at 554-63.

134. See, e.g., Civil Liberties for Urban Believers v. City of Chicago, 342 F.3d 752 (7th Cir. 2003); City of Woodinville v. Northshore United Church of Christ, 162 P.2d 427 (Wash. Ct. App. 2007); Hollywood Cmty. State ex rel. Scadden v. Willhite, 2002 Ohio 1352 (Ct. App. 2002); Synagogue, Inc. v. City of Hollywood, 430 F. Supp. 2d 1296 (S.D. Fla. 2006).

135. 42 U.S.C. $\S 2000 \mathrm{cc}-5(7)(B)$. RFRA, by contrast, originally defined religious exercise as the "exercise of religion under the First Amendment to the Constitution[.]" Religious Freedom Restoration Act of 1993, Pub. L. No. 103-141, § 5, 107 Stat. 1488 (1993).

136. Cambodian Buddhist Soc'y, 2008 WL 248053, at*14.

137. Id. at $* 13$ (internal quotation marks omitted) (quoting Lakewood, Ohio Congregation of Jehovah's Witnesses v. Lakewood, 699 F.2d 303, 307 (6th Cir. 1983)). The Connecticut Supreme Court further noted that "[o]ur research . . . has revealed no pre-Smith cases supporting the proposition that the construction and use of a place of worship constitutes the exercise of religion per se. Indeed, the weight of authority is to the contrary." Id. at *13 n.20.

138. $I d$. at $* 16$.

139. The court seemed to rely on RLUIPA's Fourteenth Amendment jurisdictional hook in formulating its conclusion that RLUIPA only applies to cases involving individualized assessments. Id. at *14 (stating that "under 42 U.S.C. $\S 2000 \mathrm{cc}(\mathrm{a})(2)(\mathrm{C})$ [the Fourteenth Amendment jurisdictional hook], the substantial burden provision of RLUIPA applies only to cases in which the 'government makes, or has in place formal or informal procedures or practices that permit the government to make, individualized assessments of the proposed uses for the property involved"'). While this section of 
A related separation of powers argument stems from the fact that RLUIPA's definition of "religious exercise" expressly applies to the use of property by religious entities, as well as by individuals. ${ }^{140}$ While it is clear that the First Amendment contemplates an organizational right to free exercise ${ }^{141}$ the Supreme Court has yet to define the contours of this right, which may be influenced by the "nature, history, and purpose of the particular constitutional provision." ${ }^{142}$ In the end, the Supreme Court, as the ultimate arbiter of the meaning of the Constitution, might someday determine that the Free Exercise Clause does not automatically protect the use of property by religious corporations in the same manner that it protects the use of property by individuals for religious purposes. If this were the case, then Congress' decision to choose the recipients of free exercise rights would likely raise separation of powers problems. One court has avoided this result by flatly rejecting the argument that that "[the Free Exercise Clause] protects only individual rights, and not the rights of religious institutions."143

So far, the separation of powers arguments against RLUIPA's constitutionality have not received much positive attention from the courts, and all of the leading cases on the issue have found RLUIPA to be in harmony with the principles of divided powers. These cases have generally found that RLUIPA did not overturn Smith or otherwise change the meaning of the Free Exercise Clause, but rather that they have merely provided heightened protection in limited circumstances. ${ }^{144}$ Nevertheless, the question of whether RLUIPA violates the doctrine of sepa-

RLUIPA does reflect the rule in Smith, the court did not explain why this jurisdictional hook should always be required, even if the Commerce or Spending Clauses might otherwise supply Congressional authority to impose RLUIPA in cases not involving individualized assessments. Indeed, the court went so far as to include RLUIPA's text in the margin but to replace the Commerce and Spending Clause provisions with ellipses. Id. at $* 1$, n. 2 .

140. See 42 U.S.C. $\$ 2000 \mathrm{cc}-5(7)$ (B) (2006).

141. See generally Developments in the Law-Religion and the State: VI. Government Regulation of Religious Organizations, 100 HARV. L. REV. 1740, 1744-45 (1987) (noting that the Supreme Court's willingness to extend standing to religious organizations evidences the existence of an institutional right to free exercise).

142. First Nat'l Bank v. Bellotti, 435 U.S. 765, 778 n.14 (1978) (holding that corporations are entitled to the right to free speech).

143. Cambodian Buddhist Soc'y, 2008 WL 248053, at *8 (citing Corp. of the Presiding Bishop of the Church of Jesus Christ of Latter-Day Saints v. Amos, 483 U.S. 327, 342 (1987) (Brennan, J., concurring)).

144. See, e.g., Lovelace v. Lee, 472 F.3d 174, 216 (4th Cir. 2006); Mayweathers v. Newland, 314 F.3d 1062, 1070 (9th Cir. 2002); Madison v. Riter, 411 F. Supp. 2d 645, 656-57 (W.D. Va. 2006); Church of the Hills v. Twp. of Bedminster, No. 05-3332 (SRC), 2006 U.S. Dist. LEXIS 9488, at *26-29 (D.N.J. Feb. 24, 2006); Castle Hills First Baptist Church v. City of Castle Hills, No. SA-01-CA-1149-RF, 2004 U.S. Dist. LEXIS 4669, at*81-83 (W.D. Tex. Mar. 17, 2004); Guru Nanak Sikh Soc'y v. County 
ration of powers will likely remain less than fully resolved until the Supreme Court rules on the issue.

\section{Operation of RLUIPA}

The drafters of RLUIPA were far from thorough in their attention to detail in terms of providing clear definitions for local governments that are responsible for the implementation of the statute, resulting in the critical elements of the land use section of the law being subject to interpretation by the courts. Additionally, their insistence that RLUIPA is a codification of existing constitutional precedent—even though it seems to have been clearly intended to modify the Smith holding-has proven to be troubling, as courts interpreting RLUIPA's poorly defined terms have vacillated between applying precedent or applying the statute in the manner conforming to Congress' perceived intentions. ${ }^{145}$ This has opened the door to inconsistent application of the terms of the statute; has created confusion among municipalities, planners and the bar; and has failed to date to create one national standard or rule with respect to the siting of religious land uses. If one argument in support of RLUIPA is the need for uniformity and clarity in the protection of the free exercise of religion, RLUIPA is failing miserably. The sections that follow provide examples of the lack of consensus with respect to the meaning of the language in the statute.

\section{A. RLUIPA's Substantial Burden Provision}

Subsection (a) of 42 U.S.C. $\S 2000$ cc lays out RLUIPA's substantial burden rule:

(1) General rule. No government shall impose or implement a land use regulation in a manner that imposes a substantial burden on the religious exercise of a person, including a religious assembly or institution, unless the govern-

of Sutter, 326 F. Supp. 2d 1140, 1161 (E.D. Cal. 2003); Goodman v. Snyder, No. 00 C 0948, 2003 U.S. Dist. LEXIS 20987, at*4-5 (N.D. Ill. Nov. 20, 2003); Life Teen, Inc. v. Yavapai County, No. CIV 01-1490 PCT RCB, 2003 U.S. Dist. LEXIS 24363, at *44-48 (D. Ariz. Mar. 26, 2003); Mayweathers v. Terhune, No. CIV S-96-1582 LKK/GGH P, 2001 U.S. Dist. LEXIS 22300, at *22-23 (E.D. Cal. July 2, 2001). Language in at least one lower court case, later overruled, intimated that separation of powers problems exist. See Elsinore Christian Center v. City of Lake Elsinore, 270 F. Supp. 2d 1163, 117683 (C.D. Cal. 2003) (holding RLUIPA to be unconstitutional on federalism grounds but drawing on separation of powers doctrine as well), overruled by Elsinore Christian Center v. City of Lake Elsinore, 197 F. App'x 718 (9th Cir. 2006). The Connecticut Supreme Court has also interpreted RLUIPA in a fashion that calls to mind separation of powers issues. Cambodian Buddhist Soc'y, 2008 WL 248053, at *14-16.

145. See, e.g., Cambodian Buddhist Soc'y, 2008 WL 248053, at *14 (describing this "interpretative quandary"). 
ment demonstrates that imposition of the burden on that person, assembly, or institution-

(A) is in furtherance of a compelling governmental interest; and

(B) is the least restrictive means of furthering that compelling governmental interest. ${ }^{146}$

Definitions are essential to this section. RLUIPA itself defines a few of the key terms, but it omits any definition of "substantial burden." That term was supposed to be defined in relation to Supreme Court precedent, ${ }^{147}$ but its precise scope has been hotly debated. Nevertheless, before proceeding to an explanation of how "substantial burden" has been interpreted, the meaning of several other words should be explored.

\section{LAND USE REGULATION}

"Land use regulation," according to RLUIPA, refers to "a zoning or landmarking law, or the application of such a law, that limits or restricts a claimant's use or development of land (including a structure affixed to land), if the claimant has [a] ... property interest in the regulated land. ..." ${ }^{148}$ Several things should be noted here. First, the courts have strictly confined RLUIPA's application to zoning and landmarking cases. Condemnation ${ }^{149}$ and other governmental actions that affect land use, such as public health ordinances and annexations, do not fall within the scope of RLUIPA. ${ }^{150}$ Secondly, religious entities may not seek the

146. 42 U.S.C $\$ 2000 \mathrm{cc}(\mathrm{a})$ (2006) (emphasis added).

147. 146 Cong. Rec. S7774, at S7776 (2000) (joint statement of Sen. Hatch, Sen. Kennedy, and Sen. Reid on the Religious Land Use and Institutionalized Persons Act of 2000). RLUIPA's sponsors explained that:

The Act does not include a definition of the term 'substantial burden' because it is not the intent of this Act to create a new standard for the definition of 'substantial burden' on religious exercise. Instead, that term as used in the Act should be interpreted by reference to Supreme Court jurisprudence. Nothing in this Act, including the requirement in Section $5(\mathrm{~g})$ that its terms be broadly construed, is intended to change that principle. The term 'substantial burden' as used in this Act is not intended to be given any broader interpretation than the Supreme Court's articulation of the concept of substantial burden or religious exercise.

Id.

148. 42 U.S.C. § $2000 c c-5(5)$ (2006).

149. See St. John's United Church of Christ v. City of Chicago, 502 F.3d 616 (7th Cir. 2007); Faith Temple Church v. Town of Brighton, 405 F. Supp. $2 d 250$ (W.D.N.Y. 2005); City and County of Honolulu v. Sherman, 129 P.2d 542 (Haw. 2006). But cf. Albanian Associated Fund v. Twp. of Wayne, No. 06-CV-3217, 2007 WL 2904194 (D.N.J. Oct. 1, 2007) (holding that although the condemnation could not be challenged under RLUIPA, the implementation of the land use plan under which the condemnation was initiated did fall within the scope of RLUIPA).

150. See Taylor v. City of Gary, 233 F. App'x 561 (7th Cir. 2007) (finding that the city's decision as to how to dispose of a church property that it owned was not a land use regulation); Vision Church v. Vill. of Long Grove, 468 F.3d 975 (7th Cir. 2006) (noting that involuntary annexation is not a land use regulation); Second Baptist Church v. Gilpin Twp., 118 F. App'x 615 (3d Cir. 2004) (holding that a mandatory sewer connection 
protection of RLUIPA for land use regulations that do not affect their own land. Accordingly, the statute was held to be inapplicable in one case where a synagogue protested that the construction of a cellular tower on neighboring property would ruin its scenic (and presumably religiously inspiring) views. ${ }^{151}$ In another case, it was held that an individual religious adherent does not have standing to challenge a land use decision affecting property owned by his or her religious organization. ${ }^{152}$ Similarly, RLUIPA is irrelevant when religious parties protest municipalities' use of government-owned land. ${ }^{153}$

\section{RELIGIOUS EXERCISE}

"Religious exercise" is defined, in part, as follows:

(A) In general. The term "religious exercise" includes any exercise of religion, whether or not compelled by, or central to, a system of religious belief. ${ }^{154}$

This subsection basically codifies what the Supreme Court made clear in Northwest Indian Cemetery Protective Association ${ }^{155}$ and Smith, ${ }^{156}$ namely, that it is improper for courts to inquire into the centrality or importance of religious conduct to an individual's religion. ${ }^{157}$ In keeping with Congress' indication that RLUIPA was meant to codify existing Supreme Court precedent, the lower courts have read a few important clarifications into this definition.

First, although courts may not inquire into the centrality or importance of religious practices, they may inquire into whether a purported "religious exercise" is, in fact, religious in nature. For example, in

ordinance was not subject to RLUIPA); Prater v. City of Burnside, 289 F.3d 417 (6th Cir. 2002) (holding that the city's decision to open a road bisecting two of the church's properties was not a land use regulation under RLUIPA).

151. Omnipoint Commc'ns, Inc. v. City of White Plains, 202 F.R.D. 402 (S.D.N.Y. 2001) rev'd on other grounds, 430 F.3d 529 (2d Cir. 2005).

152. Cambodian Buddhist Soc'y v. Planning \& Zoning Comm'n of Newtown, No. 17690, 2008 WL 248053, at *6 (Conn. Feb. 12, 2008).

153. See, e.g., Taylor v. City of Gary, 233 F. App'x 561 (7th Cir. 2007) (finding that the city's decision as to how to dispose of a church property that it owned was not a land use regulation); Prater v. City of Burnside, 289 F.3d 417 (6th Cir. 2002) (holding that the city's decision to open a road bisecting two of the church's properties was not a land use regulation under RLUIPA).

154. 42 U.S.C. § 2000cc-5(7) (2006).

155. Lyng v. Nw. Indian Cemetery Protective Ass'n, 485 U.S. 439 (1988).

156. Employment Div. v. Smith, 494 U.S. 872 (1990).

157. See Employment Div., 494 U.S. at 886-87 (discussing Lyng v. Nw. Indian Cemetery Protective Ass'n, 485 U.S. 439 (1988)). Interestingly, however, RFRA originally defined "religious exercise" as "the exercise of religion under the First Amendment to the Constitution." Religious Freedom Restoration Act of 1993, Pub. L. No. 103-141, 107 Stat. 1488, § 5 (1993). Apparently, Congress decided in RLUIPA that it was necessary to explain in more detail what the exercise of religion under the First Amendment means. 
Beechy v. Central Michigan District Health Department ${ }^{158}$ Amish homeowners refused to comply with a requirement that they install septic systems. ${ }^{159}$ The court determined that the plaintiffs could state claims neither under RLUIPA nor under the First Amendment, because the plaintiffs' contentions were cultural and practical in nature, rather than truly religious. ${ }^{160}$

Moreover, RLUIPA does not prohibit the courts from inquiring into the sincerity of religiously held beliefs. ${ }^{161}$ The Tenth Circuit has held that a finding of sincerity is a prerequisite for employing the substantial burden test, and other courts should take note. ${ }^{162}$

RLUIPA does not stop here, however, in its definition of religious exercise. It continues:

(B) Rule. The use, building, or conversion of real property for the purpose of religious exercise shall be considered to be religious exercise of the person or entity that uses or intends to use the property for that purpose. ${ }^{163}$

A few courts have seized on the fact that this aspect of the definition of "religious exercise" expands upon the Supreme Court's prior understanding of the term, as the Free Exercise Clause was never specifically interpreted to include land use as a type of religious exercise. ${ }^{164}$ Generally,

158. 475 F. Supp. 2d 671 (E.D. Mich. 2007).

159. Id. at 672 .

160. Id. at 684 .

161. The element of sincerity has long been employed in Free Exercise Clause jurisprudence. See, e.g., Cutter v. Wilkinson, 544 U.S. 709, 725 n.13 (2005) (stating that "[a]lthough RLUIPA bars inquiry into whether a particular belief or practice is 'central' to a prisoner's religion ... the Act does not preclude inquiry into the sincerity of a prisoner's professed religiosity"); Employment Div., 494 U.S. at 907 (O'Connor, J., concurring); United States v. Ballard, 322 U.S. 78, 85-88 (1944); Tony and Susan Alamo Found. v. Sec'y of Labor, 471 U.S. 290, 303-05 (1985).

162. See Grace United Methodist Church v. City of Cheyenne, 451 F.3d 643 (10th Cir. 2006). In Grace United, the district court erroneously instructed the jury that a "substantial burden" was one that burdened activity "fundamental" to a religion. The Tenth Circuit, however, found this error to be harmless, because the jury had already been correctly instructed that the sincerity of a religious belief was an element of the claim. As a consequence of the jury's finding that the church's activity was not a sincere exercise of its religion, "the substantial burden issue became irrelevant." Id at 663-64.

163. 42 U.S.C. $\$ 2000 \mathrm{cc}-5(7)(2006)$.

164. See, e.g., Lighthouse Inst. for Evangelism, Inc. v. City of Long Branch, 510 F.3d 253, 273 (3d Cir. 2007) (explaining that "unlike RLUIPA, which explicitly defines as religious exercise: 'The use, building, or conversion of real property for the purpose of religious exercise,' the Free Exercise Clause does not define land use as a religious exercise"); Congregation Kol Ami v. Abington Twp., No. 01-1919, 2004 U.S. Dist. LEXIS 16397, at *19 n.3 (E.D. Pa. Aug. 12, 2004) (noting that "[a]lthough the RFRA was eventually found unconstitutional for impermissibly expanding free exercise rights, the law did not attempt to change the definition of what constituted a substantial burden on free exercise. [C]ompare the RFRA [definition of 'religious exercise'] with the RLUIPA [definition of 'religious exercise']"); Cambodian Buddhist Soc'y v. Planning \& Zoning Comm'n of Newtown, No. 17690, 2008 WL 248053, at*13 (Conn. Feb. 12, 
the courts have been pragmatic in interpreting this section. The District Court for the District of Massachusetts, for example, explained that "[o]f course, every building owned by a religious organization does not fall within this definition. Buildings used by religious organizations for secular activities or to generate revenue to finance religious activities are not automatically protected." 165 The Second Circuit, likewise, has indicated that the proposed use of a building must be religious in order to gain protection under RLUIPA as a "religious exercise."166 The court suggested that a gymnasium sought to be built by a religious school, or a headmaster's residence, would not necessarily qualify as such. ${ }^{167}$ Another court referenced Congress' intent in enacting RLUIPA as support for its conclusion that "a burden on commercial enterprise used to fund a religious organization does not constitute a substantial burden on 'religious exercise' within the meaning of RLUIPA."'168

Thus, a critical question not yet clearly answered is whether RLUIPA's protection of the exercise of religion is limited to obviously religious uses, or whether it extends to arguably secular activities carried out by religious institutions. Resolution of this issue is even more critical for

2008). See also American Commc'ns Ass'n v. Douds, 339 U.S. 382, 397-98 (1950), where the Chief Justice Vinson explained that

[w] hen the effect of a statute or ordinance upon the exercise of First Amendment freedoms is relatively small and the public interest to be protected is substantial, it is obvious that a rigid test requiring a showing of imminent danger to the security of the Nation is an absurdity. We recently dismissed for want of substantiality an appeal in which a church group contended that its First Amendment rights were violated by a municipal zoning ordinance preventing the building of churches in residential areas.

Id.

165. Mintz v. Roman Catholic Bishop, 424 F. Supp. 2d 309, 318 (D. Mass. 2006).

166. Westchester Day Sch. v. Vill. of Mamaroneck, 504 F.3d 338, 347-48 (2d Cir. 2007).

167. Id.; see also Westchester Day Sch. v. Vill. of Mamaroneck, 417 F. Supp. 2d 477, 543-46 (S.D.N.Y. 2006) (explaining that a building may be found to be a "religious exercise" even though it has both religious and secular purposes) aff' $d, 504$ F.3d 338 (2d Cir. 2007); Chase v. City of Portsmouth, No. 2:05cv446, 2005 U.S. Dist. LEXIS 29551 , at $* 21$ (E.D. Va. Nov. 16, 2005) (explaining that "while the substantial burden required under the RLUIPA and that required under the Free Exercise Clause are related, there are important differences relating to their distinct definitions of 'religious exercise.' In contrast to the substantial burden required under RLUIPA, a substantial burden under the Free Exercise Clause is confined to the practices and beliefs of a religion, not associated land use. Therefore, it is necessary to acknowledge that, while the definitions are highly related, the Religious Land Use and Institutionalized Persons Act is appropriately focused on land use, while the Free Exercise Clause is focused on beliefs and practice.") (internal citations omitted) (emphasis in original).

168. Scottish Rite Cathedral Ass'n of Los Angeles v. City of Los Angeles, $156 \mathrm{Cal}$. App. 4th 108, 119 (Ct. App. 2007). 
local governments that, according to a recent article in the New York Times, might expect to see churches seeking approval for a host of auxiliary activities. ${ }^{169}$ For example, one 4,000-member congregation in Anchorage, Alaska, co-owns a warehouse that houses a Sysco, and the church developed and financed a sports arena. ${ }^{170}$ The New York Times discovered this was not unique, as many "mega churches" list business interests including basketball schools, aviation subsidiaries, investment partnerships and limousine services. Religious organizations even sponsor credit unions, issue credit cards, and lend to small businesses. ${ }^{171}$ Further, the Times reported that at least ten churches own and operate shopping centers, and some own and operate residential developments. ${ }^{172}$ The article further points out that many of these churches believe that the operation of these types of ventures are religious in nature, as they are an opportunity to evangelize. ${ }^{173}$ The Anchorage church, for example, explained that its sports dome offers a way to draw the attention of young families and inform them about the church's programs. ${ }^{174}$ In another news report, Forbes described churches that operate music studios, radio stations, and publishing houses. ${ }^{175}$ It is not uncommon to find churches housing dining facilities, movies, gyms, community centers, and food pantries. ${ }^{176}$ In addition, churches may run hospitals, manage retails stores, and run radio broadcasting operations. ${ }^{177}$

169. Diana B. Henriques \& Andrew W. Lehren, In God's Name: MegaChurches Add Local Economy to Their Mission, N.Y. TIMEs, Nov. 23, 2007, at A1, available at http:// www.nytimes.com/2007/11/23/business/23megachurch.html?pagewanted=1.

170. Id.

171. Id. The article reports, for example, that

[t]he Evangelical Christian Credit Union in Brea, Calif., a pioneer in lending to churches and a proxy for this market shift, has seen its loan portfolio grow to $\$ 2.7$ billion, from just $\$ 60$ million in the early 1990 s, said Mark A. Johnson, its executive vice president. Where bankers were once reluctant to lend to churches, the credit union now shares a market with some of the nation's largest banks.

Id.

172. Id. The article also reported that the LifeBridge Christian Church near Longmont, Colorado, is planning for the development of upscale homes, retail and office space, a sports arena, housing for the elderly, and church buildings on a 313-acre parcel. Id.

173. Id. A pastor quoted in the article explained that "[w]e don't look at this as economics; we look at it as our mission." Id.

174. Henriques, supra note 169.

175. Luisa Kroll, Christian Capitalism: Megachurches, Megabusinesses, Forbes, Sep. 17, 2003, available at http://www.forbes.com/2003/09/17/cz_lk_0917megachurch. html.

176. See Sara C. Galvan, Beyond Worship: The Religious Land Use and Institutionalized Persons Act of 2000 and Religious Institutions' Auxiliary Uses, 24 YALE L. \& POL'y REv. 207 (2006).

177. Id. 
So far, houses of worship have easily been viewed as religious uses by the courts. ${ }^{178}$ Schools and other facilities for religious education have also been held by most courts to be religious uses. ${ }^{179}$ One court held that a faith-based drug and alcohol rehabilitation center was a "religious exercise" under RLUIPA. ${ }^{180}$ In another case, a religious hospital was considered as - but not conclusively determined to be-a religious exercise. ${ }^{181}$ Apartment complexes, performance spaces, office buildings and day care centers, however, do not become "religious exercises" simply because they are owned or operated by religious organizations. ${ }^{182}$ At least one court, though, has found faith-based daycare to be religious in nature. ${ }^{183}$

\section{TOWARDS DEFINING A "SUBSTANTIAL BURDEN"}

The general rule in Section 2 of the statute provides, in part, that "[n]o government shall impose or implement a land use regulation in a

178. See, e.g., Guru Nanak Sikh Soc'y v. County of Sutter, 456 F.3d 978 (9th Cir. 2006); Mintz v. Roman Catholic Bishop, 424 F. Supp. 2d 309 (D. Mass. 2006); Cathedral Church of the Intercessor v. Inc. Vill. of Malverne, No. CV 02-2989 (TCP) (MO), 2006 WL 572855 (E.D.N.Y. Mar. 6, 2006); Congregation Kol Ami v. Abington Twp., No. 01-1919, 2004 U.S. Dist. LEXIS 16397, at *27 (E.D. Pa. Aug. 17, 2004); Cottonwood Christian Ctr. v. Cypress Redevelopment Agency, 218 F. Supp. 2d 1203, 1224 (C.D. Cal. 2002) (noting that "Cottonwood is seeking to build a church, not a skyscraper. Its proposed use is unquestionably religious, not commercial."); see also DiLaura v. Ann Arbor Charter Twp., 30 F. App'x 501 (6th Cir. 2002) (involving a house used for religious retreats).

179. See, e.g., Living Water Church of God v. Charter Twp. of Meridian, Nos. 052309, 06-1210, 2007 U.S. App. LEXIS 28825 (6th Cir. Dec. 10, 2007); Westchester Day Sch. v. Vill. of Mamaroneck, 504 F.3d 338 (2d Cir. 2007); San Jose Christian Coll. v. City of Morgan Hill, 360 F.3d 1024, 1034 (9th Cir. 2004); Castle Hills First Baptist Church v. City of Castle Hills, No. SA-01-CA-1149-RF, 2004 U.S. Dist. LEXIS 4669 (W.D. Tex. Mar. 17, 2004); Shepherd Montessori Ctr. Milan v. Ann Arbor Charter Twp., 675 N.W.2d 271, 280-81 (Mich. Ct. App. 2003) (noting that "a faith-based primary school . . . falls within this broad definition of a religious exercise").

180. Men of Destiny Ministries, Inc. v. Osceola County, No. 6:06-CV-624-Orl31DAB, 2006 U.S. Dist. WL 3219321, at*11-12 (M.D. Fla. Nov. 6, 2006).

181. Sisters of St. Francis Health Servs. v. Morgan County, 397 F. Supp. 2d 1032, 1050 (S.D. Ind. 2005).

182. See, e.g., Grace United Methodist Church v. City of Cheyenne, 451 F.3d 643 (10th Cir. 2006) (day care); Greater Bible Way Temple of Jackson v. City of Jackson, 733 N.W.2d 734, 745-46 (Mich. 2007) (apartments); Scottish Rite Cathedral Ass'n of Los Angeles v. City of Los Angeles, 156 Cal. App. 4th 108 (Ct. App. 2007) (theater); Conference Ass'n v. Clark County, 74 P.3d 140, 144-45 (Wash. Ct. App. 2003) (office building); see also City of Hope v. Sadsbury Twp. Zoning Hearing Bd., 890 A.2d 1137 (Pa. Commw. Ct. 2006) (not specifically deciding that a campground was not a religious exercise, but finding that the township's regulation of campgrounds were not substantial burdens); State ex rel. Scadden v. Willhite, 2002 Ohio 1352 (Ct. App. 2002) (not reaching the question of whether a mulch business located on the minister's property and used to support the church was a religious use).

183. Living Water Church of God v. Meridian, 384 F. Supp. 2d 1123 (W.D. Mich. 2005), rev'd on other grounds, Nos. 05-2309, 06-1210, 2007 U.S. App. LEXIS 28825 (6th Cir. Dec. 10, 2007). 
manner that imposes a substantial burden on the religious exercise of a person. ..." 184 If a firm understanding of "religious exercise" has eluded the courts, the disagreement over the meaning of that term pales in comparison to the controversy among the courts in defining "substantial burden." This is one of the two major triggers for applicability of RLUIPA, ${ }^{185}$ yet the statute is silent with respect to exactly what constitutes a "substantial burden" on the exercise of religion. The legislative history indicates that the term "is not intended to be given any broader interpretation than the Supreme Court's articulation of the concept of substantial burden or religious exercise." ${ }^{186}$ Given the fact that the Supreme Court never firmly defined the term, however, the cases under RLUIPA have struggled to reach the appropriate definition. ${ }^{187}$ The circuit courts have accordingly been inconsistent in their determination of what constitutes a "substantial burden," and the discussion that follows focuses on how courts are defining "substantial burden" and what types of things have and have not been found to effect a "substantial burden" on the exercise of religion.

184. 42 U.S.C. $\S 2000 \mathrm{cc}$ (a) (2006) (emphasis added).

185. The other major trigger is the "equal terms" provision. See discussion infra Part IV.B.

186. See 146 Cong. Rec. S7774, at S7776 (2000) (joint statement of Sen. Hatch, Sen. Kennedy, and Sen. Reid on the Religious Land Use and Institutionalized Persons Act of 2000). Most of the lower federal and states courts have agreed that the meaning of "substantial burden" should be gleaned from Free Exercise Clause jurisprudence. See, e.g., Living Water Church of God v. Charter Twp. Meridian, Nos. 05-2309, 06-1210, 2007 U.S. App. LEXIS 28825, at*14 (6th Cir. Dec. 10, 2007); Vision Church v. Vill. of Long Grove, 468 F.3d 975, 996-97 (7th Cir. 2006); Grace United Methodist Church v. City of Cheyenne, 451 F.3d 643, 661 (10th Cir. 2006); Christian Methodist Episcopal Church v. Montgomery, No. 4:04-CV-22322-RBH, 2007 WL 172496 (D.S.C. Jan. 18, 2007); Mintz v. Roman Catholic Church, 424 F. Supp. 2d 309, 319 (D. Mass. 2006); Church of the Hills v. Twp. of Bedminster, No. CIV 05-3332 (SRL), 2006 WL 462674 (D.N.J. Feb. 24, 2006); Lighthouse Inst. for Evangelism, Inc. v. City of Long Branch, 406 F. Supp. 2d 507, 515 (D.N.J. 2005), rev'd on other grounds, 510 F.3d 253 (3d Cir. 2007); Castle Hills First Baptist Church v. City of Castle Hills, No. SA-01-CA-1149RF, 2004 U.S. Dist. LEXIS 4669 (W.D. Tex Mar. 17, 2004). A few courts, however, have decided otherwise, claiming that RLUIPA, rather, expanded upon the protection provided by the First Amendment. See, e.g., Lighthouse Inst. for Evangelism, Inc. v. City of Long Branch, 510 F.3d 253, 274-75 (3d Cir. 2007) (explaining that while RLUIPA requires a substantial burden, the Free Exercise Clause requires only a burden); Chase v. City of Portsmouth, No. Civ.A. 2:05CV, 2005 WL 3079065 (E.D. Va. Nov. 16, 2005); Congregation Kol Ami v. Abington Twp., No. Civ.A. 01-1919, 2004 WL 1837037 (E.D. Pa. Aug. 17, 2004).

187. One recent court observed that "[i]n the 'Free Exercise' context, the Supreme Court has made clear that the 'substantial burden' hurdle is high and that determining its existence is fact intensive." Living Water Church of God, 2007 U.S. App. LEXIS 28825 , at $* 14$. 


\section{a. Tests for Substantial Burden}

In late 2007, the Sixth Circuit had the opportunity to review the tests developed by its sister circuits to determine what constitutes a substantial burden in Living Water Church of Godv. Charter Township of Meridian. ${ }^{188}$ The court noted that under the statute, albeit in the prisoner context, the Fourth Circuit finds a substantial burden on religious exercise where the regulation "put[s] substantial pressure on an adherent to modify his behavior and to violate his beliefs." 189 The Seventh Circuit first said that "a land-use regulation that imposes a substantial burden on religious exercise is one that necessarily bears direct, primary, and fundamental responsibility for rendering religious exercise-including the use of real property for the purpose thereof within the regulated jurisdiction generally - effectively impracticable." 190 Two years later, the same court said that "delay, uncertainty, and expense" would constitute a substantial burden, ${ }^{191}$ although it reaffirmed its earlier formulation shortly thereafter. ${ }^{192}$ The Ninth Circuit held that a " 'substantial burden' on 'religious exercise' must impose a significantly great restriction or onus upon such exercise." 193 Finally, the Eleventh Circuit said that a substantial burden "must place more than [a mere] inconvenience on religious exercise; a 'substantial burden' is akin to significant pressure which directly coerces the religious adherent to conform his or her behavior accordingly." 194

Ultimately, the Sixth Circuit chose not to adopt a particular definition of "substantial burden." It noted, however, that it had previously found a substantial burden where the denial of a variance "effectively barred the plaintiffs from using the property in the exercise of their religion[.]"195 The court also declined to apply a different meaning of "substantial burden" when there was a facial challenge to the zoning ordinance as opposed to an as applied challenge. ${ }^{196}$

188. $I d$.

189. Lovelace v. Lee, 472 F.3d 174, 187 (4th Cir. 2006) (quoting Thomas v. Review Bd. of Ind. Employment Sec. Div., 450 U.S. 707, 718 (1981)).

190. Civil Liberties for Urban Believers v. City of Chicago, 342 F.3d 752, 761 (7th Cir. 2003).

191. Sts. Constantine \& Helen Greek Orthodox Church, Inc. v. City of New Berlin, 396 F.3d 895, 901 (7th Cir. 2005).

192. Vision Church v. Vill. of Long Grove, 468 F.3d 975 (7th Cir. 2006).

193. San Jose Christian Coll. v. City of Morgan Hill, 360 F.3d 1024, 1034 (9th Cir. 2004).

194. Midrash Sephardi, Inc. v. Town of Surfside, 366 F.3d 1214, 1227 (11th Cir. 2004).

195. Living Water Church of God v. Charter Twp. of Meridian, Nos. 05-2309, 061210, 2007 U.S. App. LEXIS 28825, at *22 (6th Cir. Dec. 10, 2007).

196. Id. 
The table appearing as an appendix at the end of this article summarizes various formulations of the meaning of "substantial burden." Internal punctuation and citations have been removed for ease of reading, and all bolded emphasis is added.

b. Analysis of Actions That Have and Have Not Constituted a Substantial Burden

(1) Permit Application Requirements The courts tend to agree that the requirement of applying for a permit or variance to construct, enlarge, or operate a worship space is not a substantial burden. ${ }^{197}$ If a zoning authority refuses to entertain an application for a permit at all, however, a substantial burden will be found. ${ }^{198}$ Once a permit application has been filed and denied, the question of substantial burden is made more difficult. It has been remarked that "if the requirement that a religious institution apply for a permit does not violate the constitution, then the denial of the permit for reasons that are neutrally and generally applicable to all persons in the jurisdiction also does not violate the constitution." 199 Determining when the denial was made for neutral reasons, however, may be a difficult task. The courts have been more likely to find a substantial burden where it is improbable that the religious group could alter its plans to conform to the demands of the land use authority (and especially where those demands are deemed unreasonable) than in

197. See, e.g., Konikov v. Orange County, 410 F.3d 1317, 1323 (11th Cir. 2005) (stating that "requiring applications for variances, special permits, or other relief provisions would not offend RLUIPA's goals"); Murphy v. Milford Zoning Comm'n, 402 F.3d 342, 353 (2d Cir. 2005) (noting that "failure to pursue a variance prevents a federal challenge to a local land use decision from becoming ripe"); Midrash Sephardi, Inc. v. Town of Surfside, 366 F.3d 1214, 1227 n.11 (11th Cir. 2004) (explaining that "[r] equiring churches and synagogues to apply for CUPs allows the zoning commission to consider factors such as size, congruity with existing uses, and availability of parking. We have found that such reasonable 'run of the mill' zoning considerations do not constitute substantial burdens on religious exercise"); Christian Methodist Episcopal Church v. Montgomery, No. 4:04-CV-22322-RBH, 2007 U.S. Dist. LEXIS 5133, at *29-31 (D.S.C. Jan. 18, 2007) (finding no substantial burden in the requirement that the property's owners, and not the tenants, had to file an application); Cambodian Buddhist Soc'y v. Planning \& Zoning Comm'n of Newtown, No. 17690, 2008 WL 248053, at *12 n.16 (Conn. Feb. 12, 2008) (noting that the amicus conceded that "the general requirement to apply for a permit does not impose a substantial burden") (emphasis in original).

198. See Konikov, 410 F.3d at 1324 n.3 (noting that "Konikov claims that he was not permitted to apply for a special exception. ... Such a prohibition might constitute a constitutional violation and substantial burden in violation of RLUIPA"); Castle Hills First Baptist Church v. City of Castle Hills, No. SA-01-CA-1149-RF, 2004 U.S. Dist. LEXIS 4669, at *38 (W.D. Tex Mar. 17, 2004) (stating that "[t]he City's refusal to accept the Church's fourth floor [special use permit] application is a substantial burden on a sincerely held religious belief because it entirely precludes the Church from seeking a permit needed for religious use of existing property and facility").

199. Cambodian Buddhist Soc'y, 2008 WL 248053, at *12 n.16. 
cases where the possibility of obtaining a permit is still open. ${ }^{200}$ Thus, filing a second application will not necessarily be a substantial burden, although it may be if there is reason to believe that doing so would not change the outcome. In this regard, substantial delay, uncertainty or expense associated with the second application may result in the finding of a substantial burden, especially if there is evidence of discrimination or unfair treatment. ${ }^{201}$

(2) Availability of Other Suitably Zoned Property When a religious organization is precluded from constructing or operating a religious use on a specific property, and reasonable alternatives are open to the religious institution, a land use regulation will not always be found to be a "substantial burden." The Seventh Circuit held that, at least in the context of high density urban areas, problems related to finding suitably zoned, affordable, and available property upon which to operate a house

200. See, e.g., Westchester Day Sch. v. Vill. of Mamaroneck, 504 F.3d 338, 349 (2d Cir. 2007); Vision Church v. Vill. of Long Grove, 468 F.3d 975, 999 (7th Cir. 2006) (finding no substantial burden and emphasizing that Vision very likely would have received permits to construct its building if it had complied with the Village's maximum size requirements); Guru Nanak Sikh Soc'y v. County of Sutter, 456 F.3d 978, 991-92 (9th Cir. 2006) (explaining that "[e]ven if Guru Nanak were once again to follow the Planning Division's detailed requirements on mitigating impacts on nearby land, history shows such extensive efforts could very well be in vain. The net effect of the County's two denials-including their underlying rationales and disregard for Guru Nanak's accepted mitigation conditions--is to shrink the large amount of land theoretically available to Guru Nanak under the Zoning Code to several scattered parcels that the County may or may not ultimately approve. Because the County's actions have to a significantly great extent lessened the prospect of Guru Nanak being able to construct a temple in the future, the County has imposed a substantial burden on Guru Nanak's religious exercise"); Sts. Constantine and Helen Greek Orthodox Church v. City of New Berlin, 396 F.3d 895, 899-900 (7th Cir. 2005); Cathedral Church of the Intercessor v. Vill. of Malverne, 353 F. Supp. 2 d 375 (E.D.N.Y. 2005) (finding no substantial burden because the permit had been granted with conditions); Cambodian Buddhist Soc'y v. Planning \& Zoning Comm'n of Newtown, No. CV030350572S, 2005 Conn. Super. LEXIS 3158, at *34-35 (Conn. Super. Ct. Nov. 18, 2005), aff'd on other grounds, No. SC 17690, 2008 Conn. LEXIS 41 (Conn. Feb. 12, 2008); Corp. of the Presiding Bishop v. City of W. Linn, 111 P.3d 1123, 1130 (Or. 2005) (explaining that " $[t]$ he expenses associated with submitting a new application do not constitute a substantial burden in and of themselves, nor does the requirement of submitting the application. The siting of a large building often involves multiple applications by the builder, changes requested by a city planning commission or city council based on zoning and similar requirements, and related legal, architectural, and engineering costs. The city gave specific reasons for denying the first application, and nothing in the record indicates that the city would not approve a revised application that met its concerns").

201. Westchester Day Sch., 504 F.3d at 349 (stating that "[w]hen the [religious claimant] has no ready alternatives, or where the alternatives require substantial 'delay, uncertainty, and expense,' a complete denial of the school's application might be indicative of a substantial burden"); Sts. Constantine and Helen Greek Orthodox Church, 396 F.3d at 900 (noting that "the 'substantial burden' provision backstops the explicit prohibition of religious discrimination in the later section of the Act"). 
of worship do not rise to the level of substantial burdens. ${ }^{202}$ In another Seventh Circuit case, the court explained that a ban on churches in one type of zone "cannot in itself constitute a substantial burden on religion, because then every zoning ordinance that didn't permit churches everywhere would be a prima facie violation of RLUIPA." ${ }^{203}$ Expanding on this reasoning, the court found that a church that had bought property in an industrial zone knowing that it would be unlikely to obtain a permit did not suffer a substantial burden. "Any such organization[,]" the court explained, "would have to show that a paucity of other land available for churches made the exclusion from the industrial zone a substantial burden to it." 204 A Connecticut court found no substantial burden when members of a religious group could worship together at their residences. ${ }^{205}$ And in an Eleventh Circuit case, the court found that an ordinance having the effect of precluding a church from using its property for religious purposes was not a substantial burden because the ordinance predated the church's acquisition of the property. ${ }^{206}$

(3) Inconvenience, Cost, and Delay In a similar vein, numerous courts have explained that the fact that compliance with land use regulations may be costly, time consuming or inconvenient does not automatically render those land use regulations substantial burdens. ${ }^{207}$ In one case, a synagogue sought to relocate to a building where religious uses were not permitted, and complained that its permit denial was

202. Civil Liberties for Urban Believers v. City of Chicago, 342 F.3d 752, 761-62 (7th Cir. 2003); see also Midrash Sephardi, Inc. v. Town of Surfside, 366 F.3d 1214, 1227 n.11 (11th Cir. 2004); Hollywood Cmty. Synagogue, Inc. v. City of Hollywood, 430 F. Supp. 2d 1296 (S.D. Fla. 2006).

203. Petra Presbyterian Church v. Vill. of Northbrook, 489 F.3d 846, 851 (7th Cir. 2007).

204. Id.

205. Cambodian Buddhist Soc'y v. Planning \& Zoning Comm'n of Newtown, No. CV030350572S, 2005 Conn. Super. LEXIS 3158 (Conn. Super. Ct. Nov. 18, 2005), affirmed on other grounds, No. SC 17690, 2008 Conn. LEXIS 41 (Conn. Feb. 12, 2008).

206. Primera Iglesia Bautista Hispana of Boca Raton, Inc. v. Broward County, 450 F.3d 1295 (11th Cir. 2006).

207. See, e.g., Vision Church v. Vill. of Long Grove, 468 F.3d 975, 997 n.19 (7th Cir. 2006) (refusing to find a substantial burden even though Vision had been seeking permission to build on the property for seven years); Midrash Sephardi, Inc. v. Town of Surfside, 366 F.3d 1214, 1227 (11th Cir. 2004) (noting that "a 'substantial burden' must place more than an inconvenience on religious exercise"); Civil Liberties for Urban Believers v. City of Chicago, 342 F.3d 752, 761-62 (7th Cir. 2003) (stating that " ' $[t]$ he harsh reality of the marketplace sometimes dictates that certain facilities are not available to those who desire them'. ... That [the religious claimants] expended considerable time and money so to [locate in Chicago] does not entitle them to relief under RLUIPA's substantial burden provision... . Otherwise, compliance with RLUIPA would require municipal governments not merely to treat religious land uses on an equal footing with 
a substantial burden because its present facilities were inadequate. ${ }^{208}$ Specifically, it argued that late attendees caused distractions due to the building's layout and that the building did not face to the east. ${ }^{209}$ The court refused to find these concerns to be compelling: late attendees, it posited, always presented a possibility of distraction; and if the congregants desired to face east during prayer, the court suggested that they could simply turn their chairs. ${ }^{210}$ In another case, a church wished to host a "tent city" on its property but could not do so because of a moratorium on development in residential zones. ${ }^{211}$ The Washington court found no substantial burden, as the church had not demonstrated that it would be more than a mere inconvenience to use its indoor facilities to minister to the poor or find property located outside of a residential zone. ${ }^{212}$ Similarly, a New York court recently held that prohibiting plaintiffs from constructing a statue within fifty feet of their property boundary was not a substantial burden because locating the statue on another part of the property would not interfere with their ability to use the statue for religious exercise. ${ }^{213}$ A Pennsylvania court found that no substantial burden emanated from not allowing a church to operate a campground and hiking trails, both because it did not interfere with the congregants' religious exercise and because other campgrounds were available. ${ }^{214}$ The court noted, "neither the [c]hurch nor its visitors will be required to forego or modify the exercise of their religion. . .."215

(4) Expansion Cases The cases involving religious organizations' requests to expand their existing facilities are fact intensive, and few generalizations can be made. Most courts look to whether the requested additions are presently needed to accommodate the congregation to determine if denial of the expansion would create a substantial burden. While "physical access to a community of worship is crucial to a reli-

nonreligious land uses, but rather to favor them in the form of an outright exemption from land-use regulations"); see also, Greater Bible Way Temple v. City of Jackson, 733 N.W.2d 734, 750 n.23 (Mich. 2007) (rejecting the proposition that "a "substantial burden' exists when there is 'delay, uncertainty, and expense' ").

208. Williams Island Synagogue, Inc. v. City of Aventura, 358 F. Supp. 2d 1207, 1209-10 (S.D. Fla. 2005).

209. Id.

210. Id. at 1215-16.

211. City of Woodinville v. Northshore United Church of Christ, 162 P.3d 427, 430-

31 (Wash. Ct. App. 2007).

212. Id. at 437.

213. Winston v. Town of Bedford, 836 N.Y.S.2d 504 (N.Y. Sup. Ct. 2007)

214. City of Hope v. Sadsbury Twp. Zoning Hearing Bd., 890 A.2d 1137, 1149 (Pa. Commw. Ct. 2006).

215. Id. 
gious observer's ability to practice both faith and religious conduct[,]" no substantial burden was found in a case where the city denied a permit for constructing a parking lot because the existing parking lot was presently adequate for the size of the congregation. ${ }^{216}$ In another case, a church's application to build a 35,000 square foot addition was rejected, but the zoning authority granted permission to build a smaller addition. The court explained that " $[t]$ he question before us here is whether the Township's denial substantially burdens Living Water's religious exercise now-not five, ten or twenty years from now. ..."217 The court found that it did not, and thus concluded that the burden imposed on the congregation by not being able to construct a building to its desired size specifications was not a substantial burden.

In these religious use expansion cases, a number of courts have rejected substantial burden claims when the religious organizations had reasonable alternatives. ${ }^{218}$ As the Second Circuit explained:

Imagine, for example, a situation where a school could easily rearrange existing classrooms to meet its religious needs in the face of a rejected application to renovate. In such case, the denial would not substantially threaten the institution's religious exercise, and there would be no substantial burden, even though the school was refused the opportunity to expand its facilities. ${ }^{219}$

A lower court in the Sixth Circuit held that no substantial burden based on inadequate facilities could be found where a church's need for additional space was due in part to the fact that it rented space to other tenants. ${ }^{220}$ On the other hand, a lower federal court in New York found a substantial burden based on an inability to expand even though the

216. Castle Hills First Baptist Church v. City of Castle Hills, No. SA-01-CA-1149RF, 2004 U.S. Dist. LEXIS 4669, at *45-46 (W.D. Tex. Mar. 17, 2004); see also Corp. of the Presiding Bishop v. City of W. Linn, 86 P.3d 1140 (Or. Ct. App. 2004) (finding no substantial burden because worshippers were able to attend church services at other locations and no showing was made that doing so caused more than an inconvenience), aff'd, 111 P.3d 1123 (Or. 2005).

217. Living Water Church of God v. Charter Twp. Meridian, Nos. 05-2309, 06-1210, 2007 U.S. App. LEXIS 28825, at *28 (6th Cir. Dec. 10, 2007); see also Corp. of the Presiding Bishop, 111 P.3d at 1130 (noting that "[t]here is no evidence in the record to suggest that the crowded conditions at the meetinghouse have forced the church to turn away anyone who wished to attend church or to eliminate or reduce church activities").

218. See, e.g., Vineyard Christian Fellowship v. City of Evanston, 250 F. Supp. 2d 961 (N.D. Ill. 2003).

219. Westchester Day Sch. v. Vill. of Mamaroneck, 504 F.3d 338, 349 (2d Cir. 2007); see also Cambodian Buddhist Soc'y v. Planning \& Zoning Comm'n of Newtown, No. CV030350572S, 2005 Conn. Super. LEXIS 3158 (Conn. Super. Ct. Nov. 18, 2005) (finding no substantial burden where adherents had other places to gather for worship), aff'd on other grounds, No. SC 17690, 2008 Conn. LEXIS 41 (Conn. Feb. 12, 2008).

220. Episcopal Student Found. v. City of Ann Arbor, 341 F. Supp. 2d 691 (E.D. Mich. 2004). 
church was able to rent additional space offsite. ${ }^{221}$ And in one Michigan case, a substantial burden was found when the religious school showed that renting additional facilities was cost-prohibitive. ${ }^{222}$

(5) Additional Considerations Related to the Substantial Burden Provision When considering whether or not a particular type of burden is substantial in the abstract, the courts do seem to agree that evidence of discriminatory treatment will increase the likelihood of a finding that a religious organization has suffered a substantial burden. ${ }^{223}$ The result of this formulation makes sense; under free exercise precedent, the application of a facially neutral law in a discriminatory manner could render the law non-neutral and not generally applicable. ${ }^{224}$ However, some courts have pointed out that reading a discrimination element into the substantial burden provision could render RLUIPA's separate antidiscrimination provisions superfluous. ${ }^{225}$

Depending on one's view of RLUIPA - as intended to restore preSmith strict scrutiny or to codify free exercise precedent-remarks made in some of the RLUIPA cases may either be viewed as eviscerating the statute or illustrating Congress' poor understanding of the Supreme Court's nuanced free exercise jurisprudence. For example, as recently noted by the Second Circuit, "the Supreme Court has held that generally applicable burdens, neutrally imposed, are not 'substantial." "226 This would seem to limit the substantial burden test only to non-neutral laws and laws not generally applied — and it should be recalled that

221. Cathedral Church of the Intercessor v. Inc. Vill. of Malverne, No. CV 02-2989 (TCP) (MO), 2006 WL 572855, at *8 (E.D.N.Y. Mar. 6, 2006) (finding a substantial burden where the church had to rent offsite facilities for its Sunday school and it had to hold several separate Sunday services to accommodate all of its members).

222. Shepherd Montessori Ctr. Milan v. Ann Arbor Charter Twp., 739 N.W.2d 664 (Mich. Ct. App. 2007).

223. See, e.g., Westchester Day Sch., 504 F.3d at 351-52; Sts. Constantine \& Helen Greek Orthodox Church v. City of New Berlin, 396 F.3d 899, 901 (7th Cir. 2005) (noting that there was a "whiff of bad faith arising from the Planning Commission[]"); Cambodian Buddhist Soc'y, 2005 Conn. Super. LEXIS 3158, at*40-42.

224. See Church of the Lukumi Babalu Aye v. City of Hialeah, 508 U.S. 520 (1993).

225. See Midrash Sephardi, Inc. v. Town of Surfside, 366 F.3d 1214, 1227 (11th Cir. 2004) (refusing to adopt the Seventh Circuit's "effectively impractical" standard for determining substantial burdens because it would "render [RLUIPA's] total exclusion prohibition meaningless"); Cambodian Buddhist Soc'y v. Planning \& Zoning Comm'n of Newtown, No. 17690, 2008 WL 248053, at *13 (Conn. Feb. 12, 2008) (noting that "although an unreasonable limitation on religious uses within a jurisdiction undoubtedly would impose a substantial burden on religious institutions, to interpret the 'substantial burden' provision as being coextensive with the 'exclusion and limits' provision would be to render one of the provisions superfluous").

226. Westchester Day Sch., 504 F.3d at 350 (citing Jimmy Swaggert Ministries v. Bd. of Equalization, 493 U.S. 378 (1990), decided just prior to Smith). 
Smith and Lukumi require strict scrutiny in these cases anyway. ${ }^{227}$ The Seventh Circuit agreed that the burdens imposed by generally applicable zoning laws

[do] not entitle [religious organizations] to relief under RLUIPA's substantial burden provision. ... Otherwise, compliance with RLUIPA would require municipal governments not merely to treat religious land uses on an equal footing with nonreligious land uses, but rather to favor them in the form of an outright exemption from land[]use regulations. ... [N]o such free pass for religious land uses masquerades among the legitimate protections RLUIPA affords to religious exercise. ${ }^{228}$

Numerous other courts have reaffirmed that RLUIPA does not prevent local governments from imposing reasonable land use regulations on religious properties. ${ }^{229}$ In most jurisdictions, RLUIPA does not provide a guarantee that a religious organization will be able to operate at any location that it desires or that it will be able to build the type of worship space that it would like without regard to size, lot design, and other common zoning regulations.

\section{COMPELLING GOVERNMENTAL INTERESTS}

Where a government regulation is found to constitute a substantial burden on the exercise of religion, RLUIPA provides that to withstand challenge, the government must show that the burden furthers a compelling governmental interest and that it is the least restrictive means of furthering that compelling governmental interest. ${ }^{230}$ The statute does not define "compelling governmental interest," leaving it to case law. ${ }^{231}$ This poses an intriguing question because, despite the Supreme Court's strong formulations of the test in Sherbert ${ }^{232}$ and Yoder, ${ }^{233}$ the compelling interest test in the broader collection of free exercise cases has been described as "watered down." 334 As such, the courts interpreting RLUIPA

227. The courts have struggled with the question of whether zoning regulations are considered to be "individualized assessments." See discussion infra Part IV.A.5.

228. Civil Liberties for Urban Believers v. City of Chicago, 342 F.3d 752, 761-62 (7th Cir. 2003).

229. See Christian Methodist Episcopal Church v. Montgomery, No. 4:04-CV22322-RBH, 2007 WL 172496, at *9 (D.S.C. Jan. 18, 2007) (stating that "[n]umerous courts have upheld zoning regulations as applied to churches as not creating a substantial burden on religion").

230. 42 U.S.C. $\$ 2000 \mathrm{cc}(2006)$.

231. See 42 U.S.C. $\$ 2000 \mathrm{cc}-5$ (not including a definition of "compelling interest"); 146 CoNG. REC. S7774 (2000) (joint statement of Sen. Hatch, Sen. Kennedy, and Sen. Reid on the Religious Land Use and Institutionalized Persons Act of 2000) (noting that RLUIPA codified the standards used in free exercise precedent).

232. Sherbert v. Verner, 374 U.S. 398 (1963).

233. Wisconsin v. Yoder, 406 U.S. 205 (1972).

234. See Transcript of Oral Argument, City of Boerne v. Flores, 521 U.S. 507 (1997), available at http://www.oyez.org/cases/1990-1999/1996/1996_95_2074/argu ment/. One Justice asked, "this Court doesn't have independence if it's construing a 
must decide whether to adopt this not-so-compelling interest test, or whether to follow Congress' more likely intention that RLUIPA incorporate the more stringent test normally associated with the compelling interest test. ${ }^{235}$ Moreover, additional problems have arisen for local governments because the courts tend to intertwine what might otherwise be a compelling government interest with the suspicion of discriminatory intent. ${ }^{236}$

To date, traffic and congestion concerns have not been found to be compelling interests under RLUIPA by any court, ${ }^{237}$ although several have noted that it would not be impossible for traffic issues to rise to that level. ${ }^{238}$ Parking issues, similarly, have not been embraced as compelling. ${ }^{239}$ Courts have also declared that the goal of preserving property values is not compelling, at least not before a municipality has provided

statute which has imported into its terms a term of art that had fairly specific meaning, i.e., compelling interest. It [the free exercise compelling interest test] was watered down considerably, but that's the statutory standard we must follow, is it not?" For a prime example of "watered down" strict scrutiny, see, e.g., Goldman v. Weinberger, 475 U.S. 503 (1986) (holding that the air force could refuse to permit a Jewish officer to wear a yarmulke while on the base).

235. At least one court has addressed this question directly and decided that "[c]ompelling governmental interests are those that protect public health, safety or welfare. ... 'The compelling interest standard ... is not 'watered ... down' but 'really means what it says" "). Westchester Day Sch. v. Vill. of Mamaroneck, 417 F. Supp. 2d 477, 550 (S.D.N.Y. 2006), aff'd, 504 F.3d 338 (2d Cir. 2007). The Seventh Circuit, it should be noted, has opted to apply the more stringent version of the compelling interest test, but it considers the nature of the test itself to be a reason for applying a limited definition of "substantial burden." As Judge Posner explained, "[u]nless the requirement of a substantial burden is taken seriously, the difficulty of proving a compelling governmental interest will free religious organizations from zoning restrictions of any kind." Petra Presbyterian Church v. Vill. of Northbrook, 489 F.3d 846, 851 (7th Cir. 2007).

236. See, e.g., Living Water Church of God v. Twp. of Meridian, 384 F. Supp. 2d $1123,1135-36$ (W.D. Mich. 2005) (explaining that "the land to building ratio chart used by the Township, although seemingly objective, was in fact meaningless. The land to building ratio has not been applied to any other proposal. It was created specifically to address Plaintiff's proposal.... The Township's application of an arbitrary school density ratio as a basis for denying Plaintiff's application for an SUP clearly indicates that the Township did not have a compelling interest in denying the SUP and denial of the SUP was not the least restrictive means of achieving the Township's legitimate governmental interest in controlling density in order to limit the negative impact on neighborhoods and infrastructures"), rev'd on other grounds, Nos. 05-2309, 06-1210, 2007 U.S. App. LEXIS 28825 (6th Cir. Dec. 10, 2007).

237. See, e.g., Mintz v. Roman Catholic Bishop, 424 F. Supp. 2d 309, 323-24 (D. Mass. 2006).

238. See, e.g., Westchester Day Sch. v. Vill. of Mamaroneck, 386 F.3d 183, 191 (2d Cir. 2004); Cambodian Buddhist Soc'y v. Planning \& Zoning Comm'n of Newtown, No. CV030350572S, 2005 Conn. Super. LEXIS 3158, at *42-44 (Conn. Super. Ct. Nov. 18, 2005), aff'd on other grounds, No. SC 17690, 2008 Conn. LEXIS 41 (Conn. Feb. $12,2008)$.

239. See, e.g., Lighthouse Cmty. Church of God v. City of Southfield, No. 05-40220, 2007 WL 30280 , at ${ }^{* 9}$ (E.D. Mich. Jan. 3, 2007). 
credible evidence that a religious use would cause property values to decrease ${ }^{240}$ Several courts have similarly determined that aesthetic impacts are not compelling. ${ }^{241}$ The "intrinsically vague" nature of architectural regulation, according to one court, precludes it from being deemed compelling, as it could too easily lead to abuses of discretion. ${ }^{242}$ That court identified several other "intrinsically vague standards," including preserving the harmony of the neighborhood, ensuring the consistent implementation of regulations and preserving property values. ${ }^{243}$

There may be compelling reasons for excluding houses of worship from certain zones within a municipality. ${ }^{244}$ The Seventh Circuit suggested that there may have been sufficient reasons for excluding religious uses from industrial districts. ${ }^{245}$ It was quick to point out, however, that the interests of the defendant in that case could not have been compelling because, prior to RLUIPA, the zoning had permitted non-religious assemblies to locate there. ${ }^{246}$ Some courts have held that the general interest in enacting and enforcing a comprehensive system of zoning and land use regulation is compelling, ${ }^{247}$ but others have not. ${ }^{248}$ One court

240. Westchester Day Sch. v. Vill. of Mamaroneck, 417 F. Supp. 2d 477, 553 (S.D.N.Y. 2006).

241. See, e.g., id. at 553-54; Castle Hills First Baptist Church v. City of Castle Hills, No. SA-01-CA-1149-RF, 2004 U.S. Dist. LEXIS 4669, at *16 (W.D. Tex. Mar. 17, 2004); Cottonwood Christian Ctr. v. Cypress Redevelopment Agency, 218 F. Supp. 2d 1203, 1228 (C.D. Cal. 2002).

242. Cambodian Buddhist Soc'y, 2005 Conn. Super. LEXIS 3158, at *42-44.

243. Id.

244. See, e.g., Lighthouse Inst. for Evangelism, Inc. v. City of Long Branch, $406 \mathrm{~F}$. Supp. 2d 507, 516 (D.N.J. 2005) (noting, though not conclusively deciding, that the city's decision to exclude churches from a revitalization zone was supported by the compelling interest of "creating an artistic and "dynamic commercial center' in place of what has been a deteriorating downtown"), aff'd, 510 F.3d 253 (3d Cir. 2007) (note that the resolution of RLUIPA's substantial burden provision was not appealed).

245. Petra Presbyterian Church v. Vill. of Northbrook, 489 F.3d 846, 851-52 (7th Cir. 2007).

246. $I d$.

247. See, e.g., Christian Methodist Episcopal Church v. Montgomery, No. 4:04-CV22322-RBH, 2007 WL 172496, *10 (D.S.C. Jan. 18, 2007); Greater Bible Way Temple v. City of Jackson, 733 N.W.2d 734, 751 (Mich. 2007) (explaining that "[i]t has long been recognized that local governments have a compelling interest in protecting the health and safety of their communities through the enforcement of the local zoning regulations. All property is held subject to the right of the government to regulate its use in the exercise of the police power so that it shall not be injurious to the rights of the community or so that it may promote its health, morals, safety and welfare. Therefore, a municipal body clearly has a compelling interest in enacting and enforcing fair and reasonable zoning regulations") (internal quotation marks and citations omitted).

248. See, e.g., Westchester Day Sch. v. Vill. of Mamaroneck, 504 F.3d 338, 353 (2d Cir. 2007) (explaining that "[t]he Village claims that it has a compelling interest in enforcing zoning regulations and ensuring residents' safety through traffic regulations. However, it must show a compelling interest in imposing the burden on religious 
held that a city could have no compelling interest to support its refusal to entertain a church's application to alter the use of its property. ${ }^{249}$

There is no consensus as to whether economic development and the rehabilitation of deteriorated neighborhoods are compelling interests. ${ }^{250}$ One court has specifically held that "revenue generation" is not a compelling interest. ${ }^{251}$ The same court, however, only a year later, held that combating urban blight was indeed a compelling governmental interest. ${ }^{252}$ As the second opinion explained, "concerns regarding the vitality of city life are of paramount importance in land use planning."253 The prevention of sprawl was found to fail the compelling interest test in one case, ${ }^{254}$ but another court held differently. ${ }^{255}$

Even where a compelling interest is found, it still may not suffice to justify the burden if the regulation at issue is not the least restrictive method of furthering that interest. Courts have found general zoning restrictions to be more restrictive than necessary when dealing with

exercise in the particular case at hand, not a compelling interest in general."); Living Water Church of God v. Twp. of Meridian, 384 F. Supp. 2d 1123, 1134-35 (W.D. Mich. 2005), rev'd on other grounds, Nos. 05-2309, 06-1210, 2007 U.S. App. LEXIS 28825 (6th Cir. Dec. 10, 2007) (explaining that while the township had an interest in regulating density and building size, it had not shown why it was compelling in this case).

249. Castle Hills First Baptist Church v. City of Castle Hills, No. SA-01-CA-1149RF, 2004 U.S. Dist. LEXIS 4669, at*67 (W.D. Tex. Mar. 17, 2004).

250. In Lighthouse Inst. for Evangelism, Inc. v. City of Long Branch, 406 F. Supp. 2d 507 (D.N.J. 2006), the court found no substantial burden, and therefore did not need to address the question of the city's asserted interests. It did, however, and noted that

the Court nonetheless finds that Long Branch's stated interest in creating an artistic and "dynamic commercial center" in place of what has been a deteriorating downtown is a legitimate and compelling governmental interest. Long Branch seeks to revitalize its downtown district by developing a performing art and artistic center, supported by restaurants, cafes, bars and specialty retail stores. The presence of a church within this limited zone would most likely not contribute to such development. In addition, a state ordinance prohibiting the sale of alcohol within two hundred feet of a religious organization and a local ordinance prohibiting the sale of alcohol within one thousand feet of a religious organization, would further restrict development on the block. For these reasons, Long Branch has a compelling interest in limiting a church within this particular zone.

Id. at 516. For the opposing view, that mitigating blight is not a compelling interest, see Cottonwood Christian Ctr. v. City of Cypress, 218 F. Supp. 2d 1203, 1228 (C.D. Cal. 2002) (finding aesthetic concerns and blight to be substantial, but not compelling interests).

251. Cottonwood Christian Ctr., 218 F. Supp. 2d at 1228.

252. Elsinore Christian Ctr. v. City of Lake Elsinore, 270 F. Supp. 2d 1163, 1173

(C.D. Cal. 2003), vacated by No. CV 01-04842 SVW (RCX), 2003 U.S. Dist. LEXIS 24057 (C.D. Cal. Aug. 21, 2003).

253. Id.

254. Greater Bible Way Temple v. City of Jackson, 708 N.W.2d 756 (Mich. 2005), rev'd, 733 N.W.2d 734 (Mich. 2007).

255. Elsinore Christian Ctr., 270 F. Supp. 2d at 1173. 
parking and traffic concerns, ${ }^{256}$ environmental controls, ${ }^{257}$ and regulations relating to aesthetics and economic development. ${ }^{258}$ Nevertheless, it should be pointed out that most of the cases holding that a regulation was more restrictive than necessary have done so unnecessarily and only after finding that no compelling interest existed.

\section{RLUIPA'S INDIVIDUALIZED ASSESSMENT PROVISION}

RLUIPA's Fourteenth Amendment jurisdictional hook states that the Act's strict scrutiny test will apply when the "substantial burden is imposed in the implementation of a land use regulation or system of land use regulations, under which a government makes, or has in place formal or informal procedures or practices that permit the government to make, individualized assessments of the proposed uses for the property involved."259 Even though the Commerce Clause jurisdictional element would seem to easily encompass most religious land use cases, ${ }^{260}$ a number of cases have premised RLUIPA's applicability on the basis that the land use decision involved constituted an individualized assessment. This has required the courts to deal with the tricky question of what exactly constitutes an individualized assessment, and more specifically, whether zoning regulations fall into that category.

The "individualized assessment" provision has more elusive roots than the Commerce and Spending Clause jurisdictional elements, and it has received more interesting treatment from the courts. The language of the provision originated in Smith, where the Court, in distinguishing Sherbert and the unemployment cases from typical free exercise claims, explained that "where the State has in place a system of individual exemptions, it may not refuse to extend that system to cases of 'religious hardship' without compelling reason." 261 The concept of individualized assessments was elaborated upon in Lukumi, where the Court applied the rule outside of the unemployment compensation context. ${ }^{262}$ The ordinance involved in Lukumi prohibited the "unnecessary" killing of animals, and the Court found that the city's interpretation of this

256. See, e.g., Westchester Day Sch. v. Vill. of Mamaroneck, 417 F. Supp. 2d 477, 551 (S.D.N.Y. 2006) (noting that "measures existed to mitigate any potential increase in traffic caused by the Project"); Lighthouse Community Church of God v. City of Southfield, No. 05-40220, 2007 WL 30280, at *9 (E.D. Mich. Jan. 3, 2007).

257. See, e.g., Westchester Day Sch., 417 F. Supp. $2 \mathrm{~d}$ at 553.

258. Cottonwood Christian Ctr., 218 F. Supp. $2 d$ at 1229.

259. 42 U.S.C. $\$ 2000 \mathrm{cc}(\mathrm{a})(2)(\mathrm{C})(2006)$.

260. See discussion supra Part III.B.1.b.

261. Employment Div. v. Smith, 494 U.S. 872, 884 (1990).

262. 508 U.S. 520 (1993). 
rule-allowing slaughter for food, hunting, and pest control, but not for religious sacrifice-involved a discriminatory system of individualized assessments. ${ }^{263}$

A number of courts have determined that RLUIPA merely codified this precedent as part of the Fourteenth Amendment jurisdictional hook. ${ }^{264}$ However, "[t]he [Supreme] Court has never explained with specificity what constitutes a 'system' of individualized exceptions[,]"265 and the lower courts have not come to a consensus about whether zoning regulations, variance procedures, and special permit requirements are individualized assessments.

Some cases state that zoning ordinances and variances inherently encompass individualized assessments. ${ }^{266}$ As explained by one district court, "[t]he process of granting zoning variances requires a case-by-

\section{Id. at 537-38. The Court explained that}

because it requires an evaluation of the particular justification for the killing, this ordinance represents a system of 'individualized governmental assessment of the reasons for the relevant conduct[.]' ... Respondent's application of the ordinance's test of necessity devalues religious reasons for killing by judging them to be of lesser import than nonreligious reasons. Thus, religious practice is being singled out for discriminatory treatment.

Id.

264. See, e.g., Sts. Constantine \& Helen Greek Orthodox Church, Inc. v. City of New Berlin, 396 F.3d 895, 897 (7th Cir. 2005); Rocky Mountain Christian Church v. Bd. of County Comm'rs, 481 F. Supp. 2d 1213, 1224-25 (D. Colo. 2007).

265. Grace United Methodist Church v. City of Cheyenne, 451 F.3d 643, 650 (10th Cir. 2006).

266. See, e.g., Konikov v. Orange County, 410 F.3d 1317, 1323 (11th Cir. 2005) (finding a system of individualized assessments because code enforcement officers were required to determine, on a case by case basis, whether a group of people constituted a "casual gathering" or an "organization"); Midrash Sephardi, Inc. v. Town of Surfside, 366 F.3d 1214, 1225 (11 th Cir. 2004) (explaining that the "assessment procedure, which results in a case-by-case evaluation of the proposed activity of religious organizations, carries the concomitant risk of idiosyncratic application of [the zoning ordinance's] standards. Surfside officials may use their authority to individually evaluate and either approve or disapprove of churches and synagogues in potentially discriminatory ways. Thus, [the zoning ordinance] is quintessentially an 'individual assessment' regime visa-vis churches and synagogues"); Church of the Hills v. Twp. of Bedminster, Civil No. 05-3332 (SRC), 2006 U.S. Dist. LEXIS 9488, at*12, *21 (D.N.J. Feb. 24, 2006); Episcopal Student Found. v. City of Ann Arbor, 341 F. Supp. 2d 691, 699 (E.D. Mich. 2004) (holding historic district regulations requiring applications to be individually reviewed to be a system of individualized assessments); Castle Hills First Baptist Church v. City of Castle Hills, No. SA-01-CA-1149-RF, 2004 U.S. Dist. LEXIS 4669, at *61 (W.D. Tex. Mar. 17, 2004) (stating that "[z]oning, and the special use permit application process specifically, inherently depend upon a system of individualized assessment"); Guru Nanak Sikh Soc'y v. County of Sutter, 326 F. Supp. 2d 1140, 1160 n.10 (E.D. Cal. 2003), aff'd, 456 F.3d 978 (9th Cir. 2006) (stating that "it is . . beyond cavil that zoning decisions such as the one at issue in this case are properly described as 'individual assessments" "); Christian Ctr. v. Cypress Redevelopment Agency, 218 F. Supp. 2d 1203, 1223 (C.D. Cal. 2002); Freedom Baptist Church v. Twp. of Middletown, 204 F. Supp. $2 d 857,868$ (E.D. Pa. 2002) (stating that "[n]o one contests that zoning ordinances 
case evaluation of the proposed activity against the prevailing land use regulations. This makes them, by necessity, 'different from laws of general applicability which do not admit to exceptions on Free Exercise grounds." "267

Many courts, however, start with the assumption that zoning ordinances are laws that are neutral and generally applicable to all, ${ }^{268}$ and neither the existence of variance procedures, nor the requirement to apply for variances, automatically renders a zoning ordinance an individualized assessment. ${ }^{269}$ The Seventh Circuit has clearly articulated this position:

Appellants appear to confuse exemption from a particular zoning provision (in the form of Special Use, Map Amendment, or Planned Development approval) with exemption from the procedural system by which such approval may be sought. Under the [zoning ordinance], these alternate avenues of zoning approval are not merely available to any would-be applicant, as Hialeah requires. They are mandatory. In short, no person, nor any nonconforming land use, is exempt from the procedural system in place for Special Use, Map Amendment, or Planned Development approval specifically, or the [zoning ordinance] generally.... [T] hus ... the [zoning ordinance] is a generally applicable system of land-use regulation. ${ }^{270}$

must by their nature impose individual assessment regimes. That is to say, land use regulations through zoning codes necessarily involve case-by-case evaluations of the propriety of proposed activity against extant land use regulations. They are, therefore, of necessity different from laws of general applicability which do not admit to exceptions on Free Exercise grounds"). There is some evidence suggesting that this is what Congress had in mind when it passed RLUIPA. See 146 Cong. REC. S7774 (2000) (joint statement of Sen. Hatch, Sen. Kennedy, and Sen. Reid on the Religious Land Use and Institutionalized Persons Act of 2000) (stating that "[c]hurches in general, and new, small, or unfamiliar churches in particular, are frequently discriminated against on the face of zoning codes and also in the highly individualized and discretionary processes of land use regulation.... [T] he codes permit churches only with individualized permission from the zoning board, and zoning boards use that authority in discriminatory ways").

267. Church of the Hills, 2006 U.S. Dist. LEXIS 9488, at *21.

268. See, e.g., Guru Nanak Sikh Soc'y v. County of Sutter, 456 F.3d 978, 987 (9th Cir. 2006) (stating that "land use regulations, such as the Zoning Code here,... typically are written in general and neutral terms"); Hale O Kaula Church v. Maui Planning Comm'n, 229 F. Supp. 2d 1056, 1070-71 (D. Haw. 2002) (explaining that "[m]erely classifying land into agricultural, rural, urban, and conservation districts does not discriminate against church buildings or uses. ... The law is facially neutral and of general applicability (although it does include a system of 'individualized assessments')").

269. See, e.g. Civil Liberties for Urban Believers v. City of Chicago, 342 F.3d 752, 764 (7th Cir. 2003) (holding Chicago's special use, map amendment and planned development processes to be neutral and generally applicable); Grace United Methodist Church v. City of Cheyenne, 451 F.3d 643, 651 (10th Cir. 2006) (noting that "although zoning laws may permit some individualized assessment for variances, they are generally applicable if they are motivated by secular purposes and impact equally all land owners in the city seeking variances").

270. Civil Liberties for Urban Believers, 342 F.3d at 764 (emphasis in original). 
The courts that treat zoning laws as neutral and generally applicable laws assess whether the implementation of a regulation, variance, or permit procedure involves an individualized assessment. Often, the courts will find an individualized assessment if the regulation includes some element of subjectivity lending itself to discretionary, and thus potentially discriminatory, application. ${ }^{271}$ Conversely, if the local zoning authority has no discretion to grant any exemptions from the specific regulation, then an ordinance will not be found to constitute an individualized assessment. ${ }^{272}$

271. See, e.g., Lighthouse Inst. for Evangelism, Inc. v. City of Long Branch, 510 F.3d 253, 275-77 (3d Cir. 2007) (including as one of the factors to take into account whether there was evidence of discriminatory enforcement); Guru Nanak Sikh Soc'y v. County of Sutter, 456 F.3d 978, 987 n.9 (9th Cir. 2006) (stating that "[O]ften, discrimination lurks behind such vague and universally applicable reasons as traffic, aesthetics, or 'not consistent with the city's land use plan.' ... Sutter County's Zoning Code implementation process is individualized and discretionary") (internal citation omitted); Grace United Methodist Church v. City of Cheyenne, 451 F.3d 643, 651 (10th Cir. 2006) (including as one of the factors to take into account whether there was evidence of discriminatory enforcement); Lighthouse Cmty. Church of God v. City of Southfield, No. 05-40220, 2007 U.S. Dist. LEXIS 28, at *14-20 (E.D. Mich. Jan. 3, 2007) (finding the application of a parking requirement not to be an individualized assessment because it was based on an objective formula, but finding that the refusal to extend a variance from that parking requirement was an individualized assessment because the zoning board had discretion to grant or deny such a variance); Murphy v. Zoning Comm'n, 289 F. Supp. 2d 87, 106-08 (D. Conn. 2003) (taking into account the testimony of the zoning enforcement officer, who explained that decisions were made based on subjective criteria), vacated, 402 F.3d 342 (2d Cir. 2005); Cottonwood Christian Ctr. v. Cypress Redevelopment Agency, 218 F. Supp. 2d 1203, 1224 (C.D. Cal. 2002) (noting that "application of the law as Defendants propose it invites deception and discrimination"); Town of Foxfield v. Archdiocese of Denver, 148 P.3d 339, 345 (Colo. App. 2006) (stating that "[a]n action constitutes an individualized assessment when the decision is based upon a subjective determination"). But cf., Civil Liberties for Urban Believers v. City of Chicago, 342 F.3d 752, 764 (7th Cir. 2003) (not assessing the subjectivity of the ordinance's criteria but finding that it had not been applied in a discriminatory manner because the city had granted permits to religious applicants).

272. See, e.g., Grace United Methodist Church, 451 F.3d at 653-54 (noting that the "zoning ordinance on its face supports the Board's conclusion that it has no authority to grant a variance for purposes of operating a daycare center in a residential zone.... The Board's mandatory denial of the Church's variance in this case is thus very different from the government employee's discretionary denial of Ms. Sherbert's unemployment benefits in Sherbert"); St. John's United Church of Christ v. City of Chicago, 401 F. Supp. 2d 887, 899 (N.D. Ill. 2005) (explaining that "[n]o facts in the complaint give rise to an inference that 'individualized exemptions from a general requirement are available.' ... In this case ... [the c]omplaint does not give rise to the inference that there exists any procedure by which any individuals within the proposed acquisition area can obtain exemptions from condemnation nor is there any indication that any individuals are exempt"); Cambodian Buddhist Soc'y v. Planning \& Zoning Comm'n of Newtown, No. 17690, 2008 WL 248053, at *16 (Conn. Feb. 12, 2008) (noting that "[i]f a zoning board has no discretion to scrutinize the reasons for land use applications and to exempt certain secular uses from zoning regulations while withholding exemptions for similarly intense religious uses, then Sherbert is inapplicable") (emphasis in original). 


\section{An Oregon court explained that}

even assuming that a governmental entity's enactments are neutral laws of general applicability, their application to particular facts nevertheless can constitute an individualized assessment-particularly where, as here, the application does not involve a mere numerical or mechanistic assessment, but one involving criteria that are at least partially subjective in nature. ${ }^{273}$

This particular formulation has been adopted by a number of courts, ${ }^{274}$ and some standards involving elements of subjectivity include whether the project is consistent with the purposes of the zoning code, whether the project is consistent with the comprehensive plan, whether the appearance of the project will be in harmony with the character of the surrounding area, or whether the project will adversely affect existing neighboring uses. ${ }^{275}$ Other cases have held that procedures allowing exemptions for "unusual and reasonable" uses ${ }^{276}$ or for "unnecessary hardship"277 involve individualized assessments.

The Tenth Circuit formulated its own approach to the individualized assessment provision in Grace United Methodist Church v. City of Cheyenne, ${ }^{278}$ a case in which a church sought, in derogation of the zoning ordinance, to operate a day care facility in a residential area. The court explained that

several "federal courts have held that land use regulations, i.e., zoning ordinances, are neutral and generally applicable notwithstanding that they may have individualized procedures for obtaining special use permits or variances." Indeed, in the land use context, the Sixth, Seventh, Eighth, and Eleventh Circuits have rejected a per se approach and instead apply a fact-specific inquiry to determine whether the regulation at issue was motivated by discriminatory animus, or whether the facts support an argument that the challenged rule is applied in a discriminatory fashion that disadvantages religious groups or organizations. ... According to these courts, although zoning laws may permit some individualized assessment for variances, they are generally applicable if they are motivated by secular purposes and impact equally all land owners in the city seeking variances. ${ }^{279}$

273. Corp. of the Presiding Bishop v. City of W. Linn, 86 P.3d 1140, 1148 (Or. Ct. App. 2004).

274. Living Water Church of God v. Charter Twp. of Meridian, 384 F. Supp. 2d 1123, 1130 (W.D. Mich. 2005), rev'd on other grounds, Nos. 05-2309, 06-1210, 2007 U.S. App. LEXIS 28825 (6th Cir. Dec. 10, 2007); Westchester Day Sch. v. Mamaroneck, 417 F. Supp. 2d 477, 542 (S.D.N.Y. 2006); Lighthouse Cmty. Church of God, 2007 U.S. Dist. LEXIS 28, at *14-15; Town of Foxfield, 148 P.3d at 345.

275. Living Water Church of God, 384 F. Supp. 2d at 1131.

276. Hale O Kaula Church v. Maui Planning Comm'n, 229 F. Supp. 2d 1056, 1073 (D. Haw. 2002)

277. Shepherd Montessori Ctr. Milan v. Ann Arbor Charter Twp., 675 N.W.2d 271, 279-80 (Mich. Ct. App. 2003).

278. 451 F.3d 643 (10th Cir. 2006).

279. Id. at 651 (internal citations omitted). The cases referred to in this quote, and cited by the lower court (Grace United Methodist Church v. City of Cheyenne, 235 
The court held that the city's refusal to issue the church a permit to operate a day care center was not part of a system of individualized assessments falling within RLUIPA's Fourteenth Amendment jurisdictional provision. ${ }^{280}$ Important in this determination were several conclusions. First, and in contrast to Lukumi, there was no evidence that the challenged zoning provision was passed because of any religious animus. ${ }^{281}$ Second, the city did not have the authority to permit the church to run a daycare facility in a residential area, as the zoning code prohibited anyone from operating such a use in a residential zone. This, the court explained, is "very different from the government employee's discretionary denial of Ms. Sherbert's unemployment benefits in Sherbert[.]" ${ }^{282}$ Moreover, there was no evidence that secular day care centers had been treated any differently from religious ones. ${ }^{283} \mathrm{In}$ sum, the court explained that

[w]hile of course it takes some degree of individualized inquiry to determine whether a person is eligible for even a strictly defined exemption, that kind of limited yes-orno inquiry is qualitatively different from the kind of case-by-case system envisioned by the Smith Court in its discussion of Sherbert and related cases. ${ }^{284}$

The Third Circuit recently rephrased the Tenth Circuit's formulation of this rule, explaining that

[a] zoning ordinance including a provision that certain enumerated uses "may be permitted by the board" was nonetheless a neutral law of general applicability, where

(1) there was no evidence that "the ordinance was passed due to religious animus,"

(2) there was no evidence that the regulation was discriminatorily enforced against religious institutions, and (3) there was no evidence that the ordinance "devalue[d] religious reasons by judging them to be of lesser import than nonreligious reasons." 285

F. Supp. 2d 1186, 1200 (D. Wyo. 2002)) as supporting the proposition that zoning laws may be neutral and generally applicable include: First Assembly of God v. Collier County, 20 F.3d 419, 423 (11th Cir. 1994); Cornerstone Bible Church v. City of Hastings, 948 F.2d 464, 472 (8th Cir. 1991); Mount Elliot Cemetery Association v. City of Troy, 171 F.3d 398, 405 (6th Cir. 1999); Rector of St. Bartholomew's Church v. City of New York, 914 F.2d 348, 354 (2d. Cir. 1990); Civil Liberties for Urban Believers v. City of Chicago, 157 F. Supp. 2d 903, 914-15 (N.D. Ill. 2001). The Tenth Circuit opinion referenced the above cases and cited, in addition, Civil Liberties for Urban Believers $v$. City of Chicago, 342 F.3d 752, 764-65 (7th Cir. 2003).

280. Grace United Methodist Church, 451 F.3d at 653.

281. Id.

282. Id. at 653-54.

283. Id. at 654 .

284. Id. (quoting Axson-Flynn v. Johnson, 356 F.3d 1277, 1298 (10th Cir. 2004)). But cf. Konikov v. Orange County, 410 F.3d 1317, 1323 (stating that "Code Enforcement Officers ... must determine in each case whether a particular use of land goes beyond occasional, casual gatherings and constitutes an 'organization' in violation of the Code. Congress was concerned about such individualized scrutiny because it runs the risk that the standards in such regulations will be applied in an unequal fashion").

285. Lighthouse Inst. for Evangelism, Inc. v. City of Long Branch, 510 F.3d 253, 277 (3d Cir. 2007) (quoting Grace United Methodist Church, 451 F.3d at 653-55). 
The individualized assessment provision was given another interpretation most recently by the Connecticut Supreme Court in Cambodian Buddhist Society v. Planning \& Zoning Commission of Newtown. ${ }^{286}$ In that case, the Society challenged the denial of its special permit application to construct a temple in a residential area. ${ }^{287}$ Whereas other courts have found individualized assessments in similar cases based on the possibility that the criteria for issuing a special permit could be applied in a subjective and discriminatory manner, ${ }^{288}$ the Connecticut court held that the special permit procedure did not constitute an individualized assessment. ${ }^{289}$ As it explained:

[In Sherbert v. Verner,] the government was authorized to treat applicants differently on the basis of the motivation for their conduct, and to treat religiously motivated conduct less favorably. ... If a zoning board has no discretion to scrutinize the reasons for land use applications and to exempt certain secular uses from the zoning regulations while withholding exemptions for similarly intense religious uses, then Sherbert is inapplicable....

... [A]lthough the commission has some discretion to determine whether a proposed specially permitted use is consistent with residential use, the regulations do not grant the commission the discretion to apply the standards differently to religious facilities than it applies them to the other uses allowed by special exception... . Rather, in reviewing each application for a special exception, the commission considers "the impact of such uses and structures upon the neighborhood and surrounding area and upon the public health, safety convenience and welfare;" and certain other criteria unrelated to the specific nature of the proposed use. We therefore conclude that ... the town's zoning regulations do not allow for an "individualized assessment," as that term is used in first amendment jurisprudence[. $]^{290}$

This formulation would seem to ignore Congress' pronouncement that "often, discrimination lurks behind such vague and universally applicable reasons as traffic, aesthetics, or 'not consistent with the city's land use plan[,]" "291 especially because the court found no individualized assessment in the special use criteria of consistency with the character of the neighborhood, ${ }^{292}$ a criteria that, although common among zoning codes, can hardly be described as wholly objective. The opinion does

286. Cambodian Buddhist Soc'y v. Planning \& Zoning Comm'n of Newtown, No. 17690, 2008 WL 248053, at*14 (Conn. Feb. 12, 2008).

287. Id. at *1.

288. See, e.g., Guru Nanak Sikh Soc'y v. County of Sutter, 456 F.3d 978 (9th Cir. 2006) (conditional use permit); Midrash Sephardi, Inc. v. Town of Surfside, 366 F.3d 1214 (11th Cir. 2004) (conditional use permit).

289. Cambodian Buddhist Soc'y, 2008 WL 248053, at *16.

290. Id. (internal citations omitted) (emphasis in original).

291. 146 CONG. REC. S7774 (2000) (joint statement of Sen. Hatch, Sen. Kennedy, and Sen. Reid on the Religious Land Use and Institutionalized Persons Act of 2000).

292. Cambodian Buddhist Soc'y, 2008 WL 248053, at *25-26. 
rest on sensible foundations, ${ }^{293}$ however, as the discrimination sought to be prevented by RLUIPA is not necessarily present when applications are denied based on such criteria as excessive traffic and increased intensity of uses. These criteria, if not totally objective, are at least measurable, and, as the court phrased it, they are "unrelated to the specific nature of the proposed use." 294 Moreover, the court correctly pointed out that the individualized assessment concept should be tied to the "reasons for the relevant conduct," 295 and not to the simple conclusion that applications are evaluated on an individual basis. The Cambodian Buddhist case will certainly influence future interpretations of RLUIPA's individualized assessment provision (and likely free exercise jurisprudence as well), ${ }^{296}$ although its effect remains to be seen. ${ }^{297}$

Finally, it should be noted that applications for rezoning are qualitatively different than applications for variances and permits and the courts may be less willing to find the denial of a rezoning request to be an individualized assessment. As the Supreme Court of Michigan explained:

A decision whether to rezone property does not involve consideration of only a particular or specific user or only a particular or specific project; rather, it involves the enactment of a new rule of general applicability, a new rule that governs all persons and all projects.... Thus, if the city had granted plaintiff's request to rezone the property from single-family residential to multiple-family residential, plaintiff could then have sold the property to any third party and that third party could have sold the property to any other third party and any of these parties could have built an apartment complex or any other conforming building on that property. Therefore, the city's decision whether to rezone the property would not have been predicated on

293. Marci Hamilton, The Connecticut Supreme Court Reaches the Right Decision in a Case Under the Religious Land Use and Institutionalized Persons Act, FInDLAW, Feb. 5, 2008, http://writ.news.findlaw.com/hamilton/20080205.html (last visited Feb. $25,2008)$.

294. Cambodian Buddhist Soc'y, 2008 WL 248053, at *16 (internal citation omitted).

295. Employment Div. v. Smith, 494 U.S. 872, 884 (1990) (emphasis added).

296. Hamilton, supra note 293.

297. The Connecticut court went farther than any other court yet has in deciding that zoning laws and special permit procedures are not individualized assessments, and its reasoning may not be found to be as persuasive as that of the Tenth and Third Circuits, which have adopted tests that take the discretionary nature of permitting procedures into account. The conclusion of the court that the Buddhist Society was not entitled to a special permit was likely correct, however. Had the court reached the question, it may have affirmed the lower court's holding that no substantial burden existed because the Society could have reapplied for a special permit when it had addressed the health and safety concerns cited by the planning commission in its denial. See Cambodian Buddhist Soc'y v. Planning \& Zoning Comm'n of Newtown, No. CV030350572S, 2005 WL 3370834, at*14 (Conn. Super. Ct. Nov. 18, 2005), aff'd on other grounds, No. 17690,2008 WL 248053 (Conn. Feb. 12, 2008). The lower court also intimated that the town's interests in traffic planning and health and safety regulations could be considered compelling interests. Id. at *14-16. 
plaintiff's particular circumstances or plaintiff's particular project.... [T]hus, the city's decision did not constitute an "individualized assessment" within the meaning of that term. ${ }^{298}$

The courts will likely face more questions like this one as different types of land use regulations are challenged under RLUIPA.

\section{B. RLUIPA's Nondiscrimination Provisions}

The second component of RLUIPA's land use provisions deals with discrimination and exclusion. It provides:

(1) Equal terms. No government shall impose or implement a land use regulation in a manner that treats a religious assembly or institution on less than equal terms with a nonreligious assembly or institution.

(2) Nondiscrimination. No government shall impose or implement a land use regulation that discriminates against any assembly or institution on the basis of religion or religious denomination.

(3) Exclusions and limits. No government shall impose or implement a land use regulation that-

(A) totally excludes religious assemblies from a jurisdiction; or

(B) unreasonably limits religious assemblies, institutions, or structures within a jurisdiction. ${ }^{299}$

\section{EQUAL TERMS}

RLUIPA's equal terms provision seems rather simple on its face, but it has raised numerous questions. A few of the earlier RLUIPA cases in the district courts suggested that a plaintiff making an equal terms challenge had to show not only disparate treatment, but also a substantial burden on its religious exercise. ${ }^{300}$ This contention has properly been rejected by the appellate courts. ${ }^{301}$ The equal terms provision, the courts have made clear, is conceptually distinct from RLUIPA's substantial burden section..$^{302}$

298. Greater Bible Way Temple v. City of Jackson, 478 Mich. 373, 389-90 (2007) (internal citations omitted).

299. 42 U.S.C. § $2000 \mathrm{cc}$ (b) (2006).

300. See, e.g., Lighthouse Inst. for Evangelism, Inc. v. City of Long Branch, $406 \mathrm{~F}$. Supp. 2d 507, 518 (D.N.J. 2005); Vineyard Christian Fellowship of Evanston, Inc. v. City of Evanston, 250 F. Supp. 2d 961, 992-93 (N.D. Ill. 2003).

301. See, e.g., Lighthouse Inst. for Evangelism, Inc. v. City of Long Branch, 510 F.3d 253, 262-64 (3d Cir. 2007); Konikov v. Orange County, 410 F.3d 1317, 1327-29 (11th Cir. 2005) (finding an equal terms violation in the absence of a substantial burden); Midrash Sephardi, Inc. v. Town of Surfside, 366 F.3d 1214, 1229-35 (11th Cir. 2004) (same finding as Konikov case); Civil Liberties for Urban Believers v. City of Chicago, 342 F.3d 752, 762 (7th Cir. 2003) (noting that "the substantial burden and nondiscrimination provisions are operatively independent of one another"); Guru Nanak Sikh Soc'y v. County of Sutter, 326 F. Supp. 2d 1140, 1154 (E.D. Cal. 2003).

302. See, e.g., Lighthouse Inst. for Evangelism, Inc., 510 F.3d at 262-64; Konikov, 410 F.3d at 1327-29 (finding an equal terms violation in the absence of a substantial 
There is some lingering debate, however, as to the proper standard of review. Some courts claim that the equal terms provision imposes strict liability, whereas others have determined that, in compelling circumstances, a regulation that does not treat religious and secular land uses equally may nevertheless be upheld. ${ }^{303}$ The Eleventh Circuit, in this regard, has drawn on the relationship of the equal terms provision to Lukumi, ${ }^{304}$ and has imposed the type of searching strict scrutiny that the Supreme Court employed in that case. ${ }^{305}$ In one case in which the plaintiffs claimed that religious uses were treated on less than equal terms with secular assemblies, the court found upon "a closer look ... that [the town] improperly targeted religious assemblies and violated Free Exercise requirements of neutrality and general applicability." ${ }^{306}$ Indeed, it makes sense that many laws that fail the equal terms test will not be neutral or generally applicable and will therefore be subject to strict scrutiny under the Free Exercise Clause alone. The equal terms provision, in this sense, may be somewhat duplicative.

The more vexing dilemma is how to determine whether a religious use has been treated on less than equal terms than a secular use. The Eleventh Circuit has described

three distinct kinds of Equal Terms statutory violations: (1) a statute that facially differentiates between religious and nonreligious assemblies or institutions; (2) a facially neutral statute that is nevertheless "gerrymandered" to place a burden solely on religious, as opposed to nonreligious, assemblies or institutions; or (3) a truly neutral statute that is selectively enforced against religious, as opposed to nonreligious assemblies or institutions. ${ }^{307}$

Under this test, the Eleventh Circuit has concluded that an ordinance treating "private clubs and other assemblies" more favorably than re-

burden); Midrash Sephardi, Inc., 366 F.3d at 1229-1235 (same finding as Konikov case); Civil Liberties for Urban Believers, 342 F.3d 762 (noting that "the substantial burden and nondiscrimination provisions are operatively independent of one another"); Guru Nanak Sikh Soc'y, 326 F. Supp. 2d at 1154.

303. See Christ Universal Mission Church v. City of Chicago, No. 01-C-1429, 2002 U.S. Dist. LEXIS 22917 , at *18 (N.D. Ill. Sept. 13, 2002) (supporting strict liability) rev'd, 362 F.3d 423 (7th Cir. 2004); Vineyard Christian Fellowship of Evanston, Inc. v. City of Evanston, 250 F. Supp. 2d 961, 993 (N.D. Ill. 2003) (noting that "[t]o bar all restrictions on religion would likely extend beyond constitutional mandates, and potentially render the statute unconstitutional").

304. Church of Lukumi Babalu Aye v. Hialeah, 508 U.S. 520, 569 (1993).

305. Midrash Sephardi, Inc. v. Town of Surfside, 366 F.3d 1214, 1232-33 (11th Cir. 2004).

306. Id. at 1232.

307. Primera Iglesia Bautista Hispana of Boca Raton, Inc. v. Broward County, 450 F.3d 1295, 1308 (11 th Cir. 2006); see also Midrash Sephardi, 366 F.3d at 1229 (noting that "while $\S(b)(1)$ has the 'feel' of an equal protection law, it lacks the 'similarly situated' requirement usually found in equal protection analysis"). 
ligious assemblies constitutes different treatment and a violation of RLUIPA's equal terms provision. ${ }^{308}$

In comparison to the Eleventh Circuit's approach, other courts have employed the use of a "similarly situated" secular comparator to identify equal terms violations. ${ }^{309}$ The Third Circuit, for example, has recently stated that its test under the equal terms provision encompass five parts:

[A] plaintiff asserting a claim under the RLUIPA Equal Terms provision must show (1) it is a religious assembly or institution, (2) subject to a land use regulation, which regulation (3) treats the religious assembly on less than equal terms with (4) a nonreligious assembly or institution (5) that causes no lesser harm to the interests the regulation seeks to advance. ${ }^{310}$

Just how to frame a similarly situated secular use has proven to be difficult. For example, the Third and Seventh Circuits have both recently decided cases involving churches that have been excluded from particular districts, partly due to state laws prohibiting the sale of alcohol near churches. The Third Circuit explained that

a regulation will violate the Equal Terms provision only if it treats religious assemblies or institutions less well than secular assemblies or institutions that are similarly situated as to the regulatory purpose. There is no need, however, for the religious institution to show that there exists a secular comparator that performs the same functions. ${ }^{311}$

Under this formulation, the court held that religious uses were not similarly situated to other types of secular assemblies permitted in the district, since they would not trigger the state alcohol law; accordingly, there was no violation of the equal terms provision. ${ }^{312}$ The Seventh Circuit, in contrast, framed the nonreligious comparator in terms of the interests sought to be protected by the alcohol restriction, and it did find a violation of the equal terms provision. Judge Posner explained that

308. Midrash Sephardi, 366 F.3d at 1219, 1231.

309. See, e.g., Lighthouse Inst. for Evangelism, Inc. v. City of Long Branch, 510 F.3d 253, 264-69 (3d Cir. 2007); Albanian Associated Fund v. Twp. of Wayne, No. 06CV-3217 (PGS), 2007 U.S. Dist. LEXIS 73176, at *31 (D.N.J. Oct. 1, 2007); Redwood Christian Schs. v. County of Alameda, No. C-01-4282 SC, 2007 U.S. Dist. LEXIS 8287, at *9-11 (N.D. Cal. Jan. 26, 2007); Vietnamese Buddhism Study Temple in Am. v. City of Garden Grove, 460 F. Supp. 2d 1165, $1173-74$ (C.D. Cal. 2006); New Life Ministries v. Charter Twp. of Mt. Morris, No. 05-74339, 2006 U.S. Dist. LEXIS 63848, at *11-16 (E.D. Mich. Sept. 7, 2006); Lighthouse Christian Ctr., Inc. v. City of Reading, No. 06-1979, 2006 U.S. Dist. LEXIS 52432, at*19-21 (E.D. Pa. June 20, 2006); Guru Nanak Sikh Soc'y v. County of Sutter, 326 F. Supp. 2d 1140, 1155 (E.D. Cal. 2003); Petra Presbyterian Church v. Vill. of Northbrook, No. 03-C-1936, 2003 U.S. Dist. LEXIS 15105 , at *37 (N.D. Ill. Aug. 29, 2003).

310. Lighthouse Inst. for Evangelism, 510 F.3d at 270.

311. Id. at 266 (emphasis in original).

312. Id. at $270-72$. 
[g]overnment cannot, by granting churches special privileges ... furnish the premise for excluding churches from otherwise suitable districts. The 200- and 500-foot protective zones give churches privileges that similarly situated secular users of C-1, other than schools, do not enjoy.... Some of the institutions permitted by the Indianapolis ordinance in C-1 districts, but not given the benefit of protective zones, such as day-care centers, nursing homes, and junior colleges-not to mention an assembly hall that might be used by the Women's Christian Temperance Union-might well be thought institutions that are "like" churches so far as anything connected with the interests protected by zoning is concerned. If so, the disparity regarding protective zones would be another example of discrimination in favor of religion (with schools tossed in perhaps just to give the impression of doling out even[]handed treatment to secular institutions that are like religious ones), which as we said cannot be a defense to a zoning exclusion challenged under the equal-terms provision of the Religious Land Use and Institutionalized Persons Act. ${ }^{313}$

Whether the equal terms provision contemplates comparisons based on the characteristics of the religious plaintiff or on the purposes of the challenged law is not a simple question, as these two cases illustrate. Moreover, they raise the issue of whether a religious use may be discriminated against on the basis of purely secular aspects-here, the fact that alcohol could not be sold near them. Interestingly, neither case involved a challenge to the state liquor law, which would seem to be the source of the unequal treatment. This may be because state liquor license laws are unlikely to qualify as "land use regulations" under RLUIPA.

Problems in interpreting the equal terms provision are likely to become more apparent as case law is amassed. Unfortunately, in this regard, "[t]he meaning of these broadly worded provisions ... is even less clear than the meaning of the "substantial burden' provision." 314

\section{NONDISCRIMINATION AND EXCLUSION}

RLUIPA's nondiscrimination provision, which forbids government from imposing or implementing land use regulations that discriminate on the basis of religion or denomination, has not inspired extensive commentary. The legislative history remarks simply that it was enacted, along with the equal terms provision, to "enforce the Free Exercise Clause rule against laws that burden religion and are not neutral and generally applicable." 315 It has been noted that the nondiscrimination provision

313. Digrugilliers v. Consol. City of Indianapolis, 506 F.3d 612, 616-17 (7th Cir. 2007).

314. Guru Nanak Sikh Soc'y v. County of Sutter, 326 F. Supp. 2d 1140, 1154 (E.D. Cal. 2003). For more information concerning the equal terms provision, its origins and implications, see Daniel Kirkpatrick, Notes \& Comments, Zoned Secular: Seattle's Prohibition of New Religious Facilities in Industrial Zones Violates the Religious Land Use and Institutionalized Persons Act's "Equal Terms" Rule, 81 WASH. L. REV. 191 (2006).

315. 146 CoNG. REC. S7774 (2000) (joint statement of Sen. Hatch, Sen. Kennedy, and Sen. Reid on the Religious Land Use and Institutionalized Persons Act of 2000). 
draws from Establishment Clause jurisprudence as well. ${ }^{316}$ Other courts have held that it requires a showing of either facial discrimination or evidence of discriminatory implementation. ${ }^{317}$ Either of those bases would likely trigger the equal terms provision as well, and the sections are often invoked together. ${ }^{318}$

RLUIPA's exclusion provisions have garnered more attention. At the outset, to raise an exclusion claim, a plaintiff must claim either that religious assemblies have been totally excluded from a jurisdiction or that they have been "unreasonably limit[ed]." that this provision was meant to codify the "well-established [principle] that a municipality cannot entirely exclude a type of conduct that the First Amendment protects." ${ }^{320}$ However, it has also been suggested that exclusion may be permissible, but only when narrowly tailored and supported by "sufficient justification." 321

The fact that religious uses are not "permitted uses" within any district of a municipality does not automatically prove exclusions exist, so long as religious organizations may obtain special permits or variances. ${ }^{322}$ Nor is a total exclusion proven when evidence is presented that the only areas in which religious uses may operate as of right have been built up. ${ }^{323}$ As the Eleventh Circuit has explained, "whatever specific difficulties the plaintiff church claims to have encountered, they are the same ones that face all land users, not merely churches. The harsh reality of the marketplace sometimes dictates that certain facilities are not available to those who desire them." 324

316. Freedom Baptist Church v. Twp. of Middletown, 204 F. Supp. 2d 857, 870 (E.D. Pa. 2002).

317. See, e.g., Sts. Constantine \& Helen Greek Orthodox Church, Inc. v. City of New Berlin, 396 F.3d 895, 900 (7th Cir. 2005); Lighthouse Inst. for Evangelism, Inc. v. City of Long Branch, 100 F. App'x 70, 77 (3d Cir. 2004); Denver First Church of the Nazarene v. Cherry Hills Village, No. 05-CV-02463-WDM-MEH, 2006 U.S. Dist. LEXIS 49483, at *8 (D. Colo. July 19, 2006); San Jose Christian Coll. v. City of Morgan Hill, No. C01-20857 RMW, 2001 U.S. Dist. LEXIS 23162, at *14-15 (N.D. Cal. Nov. 19, 2001).

318. See, e.g., Petra Presbyterian Church v. Vill. of Northbrook, 409 F. Supp. 2d 1001, 1007 (N.D. Ill. 2006); Freedom Baptist Church, 204 F. Supp. 2d at 857.

319. 42 U.S.C. $\S 2000 \mathrm{cc}(\mathrm{b})(3)$ (2006).

320. Freedom Baptist Church, 204 F. Supp. 2d at 870 (citing Schad v. Borough of Mount Ephraim, 452 U.S. 61, 68 (1981)).

321. Vision Church v. Vill. of Long Grove, 468 F.3d 975, 988-89 (7th Cir. 2006).

322. See, e.g., Vision Church, 468 F.3d at 990; Guru Nanak Sikh Soc'y v. County of Sutter, 326 F. Supp. 2d 1140, 1141-42 (E.D. Cal. 2003); Elsinore Christian Ctr. v. City of Lake Elsinore, No. CV-01-04842 SVW (RCx), 2003 U.S. Dist. LEXIS 11491, at *6 n.3 (C.D. Cal. June 25, 2003).

323. See, e.g., Petra Presbyterian Church v. Vill. of Northbrook, 409 F. Supp. 2d 1001, 1007 (N.D. Ill. 2006).

324. Midrash Sephardi, Inc. v. Town of Surfside, 366 F.3d 1214, 1227 n.11 (11th Cir. 2004) (internal quotation marks and citation omitted). 
As to "unreasonable limits" on religious uses, the legislative history explains that " $[w]$ hat is reasonable must be determined in light of all the facts, including the actual availability of land and the economics of religious organizations." ${ }^{25}$ As one court has remarked, however, this "provision suggests that Congress contemplated that religious assemblies could be reasonably limited within a jurisdiction." ${ }^{326}$

There is some indication that religious restrictions may be unreasonable if they operate according to the unbridled discretion of local officials, but in such a case a plaintiff must do more than raise a facial challenge-it must show that such discretion, as used, was in fact unreasonable. ${ }^{327}$ Another court has found generally applicable zoning regulations restricting the locations of all non-agricultural properties, including religious ones, to be reasonable. ${ }^{328}$

\section{RLUIPA and Attorneys' Fees}

Finally, it should be noted that, pursuant to 42 U.S.C. $\S 1988$, the prevailing party in a RLUIPA case can collect legal fees. ${ }^{329}$ As one attorney recently concluded:

The possibility of gaining an exemption from burdensome zoning regulations, along with the tempting prospect of recovering attorneys fees if success in litigation follows, gives religious land owners an almost irresistible incentive to assert claims of religious discrimination if they face opposition to their use or proposal, if only to gain strategic leverage in the land use approval process. ${ }^{330}$

Status as a "prevailing party" is awarded when a plaintiff succeeds "on any significant issue in litigation which achieve[s] some of the benefit the parties sought in bringing suit." ${ }^{331}$ Expert witness fees, however, have been held not to be available in a RLUIPA claim. ${ }^{332}$

325. 146 Cong. REc. E. 1564 (2000) (statement by Rep. Hyde on the Religious Land Use and Institutionalized Persons Act of 2000).

326. Konikov v. Orange County, 302 F. Supp. 2d. 1328, 1345-46 (M.D. Fla. 2004), aff'd, 410 F.3d 1317 (11th Cir. 2005).

327. See, e.g., Vision Church v. Vill. of Long Grove, 468 F.3d 975, 990-91 (7th Cir. 2006).

328. Primera Iglesia Bautista Hispana of Boca Raton, Inc. v. Broward County, No. 01-6530-CIV-MARTINEZ/KLEIN, 2004 U.S. Dist. LEXIS 25570, at*39 (S.D. Fla. Sept. 30, 2004).

329. 42 U.S.C. $\S 1988$ (b) (stating that "[i]n any action or proceeding to enforce a provision of . . the Religious Land Use and Institutionalized Persons Act of 2000 . . the court, in its discretion, may allow the prevailing party, other than the United States, a reasonable attorney's fee as part of the costs").

330. Jeffrey H. Goldfien, Thou Shalt Love Thy Neighbor: RLUIPA and the Mediation of Religious Land Use Disputes, 2006 J. DisP. RESOL. 435 (2006).

331. DiLaura v. Twp. of Ann Arbor, 471 F.3d 666, 667 (6th Cir. 2006).

332. See New Life Ministries v. Charter Twp. of Mt. Morris, No. 05-74339, 2006 WL 2927674, at *3 (E.D. Mich. Oct. 12, 2006) (explaining that the plaintiff was not entitled to expert fees under RLUIPA because the statute does not authorize them). See 
The fees in RLUIPA claims can be significant. For example, in a recent case from Michigan, the magistrate judge awarded legal fees for the plaintiffs in the amount of $\$ 178,535.61 .^{333}$ This amount does not reflect the entire cost of the litigation to the municipality, which must also pay its own legal fees, and it pales in comparison to recent fees reported in the news. ${ }^{334}$ The trend has been for municipalities to retain their own outside legal counsel and experts in RLUIPA cases, and this amount can match, if not exceed, the plaintiff's costs. For example, estimates are that the Village of Pomona, New York could incur legal fees of $\$ 1000$ per hour to defend a current RLUIPA challenge brought by the Congregation Rabbinical College of Tartikov. ${ }^{335}$ It has cost the Village of Mamaroneck, New York hundreds of thousands of dollars in the Westchester Day School litigation, ${ }^{336}$ which recently settled for $\$ 4.5$ million. ${ }^{337}$

According to a local legislator, "[s]ome municipalities have begun to 'rubber stamp' approval of any development proposed by a religious organization for fear of litigation costs" and he claims that "[m] unicipalities have shied away from giving certain proposals the scrutiny they deserve because of the potential legal bills." 338 This section of the statute provides the strongest example of how and why a well-intentioned civil rights law designed to protect religious freedoms has turned into a powerful sword on the part of religious groups who are using the threat of the statute to coerce local governments.

\section{RLUIPA, Local Governments and Communities}

Calls for repeal and reform of RLUIPA have emerged from various parts of the country. Professor Marci Hamilton has called the law

also 42 U.S.C. 1988(c) (2006) (not listing RLUIPA as one of the actions for which expert fees are available).

333. Brief of Plaintiffs-Appellants at *v, DiLaura v. Twp. of Ann Arbor, No. 052482 (6th Cir. Apr. 17, 2006).

334. See, e.g., Mamaroneck: Settlement Over School Building, N.Y. TIMES, Jan. 16 , 2008, at B5, available at http://www.nytimes.com/2008/01/16/nyregion/16mbrfsschoolhouse.html?_r=1\&oref=slogin (noting that the Village of Mamaroneck settled its litigation with Westchester Day School for $\$ 4.75$ million) [hereinafter Mamaroneck].

335. See Village Legal Fees to Fight Rabbinical College Could Be $\$ 1,000$ an Hour, Vos Iz Neias: (Yiddish: "What's News"), http://www.vosizneias.com/2007/08/pomonany-village-legal-fees-to-fight.html (last visited Feb. 25, 2008). The fees consist of a retained legal expert (law professor) at $\$ 700$ per hour plus a law firm whose rate is $\$ 375$ per hour up until the trial. This does not include other fees incurred by the law firm in defending its municipal client.

336. Press Release, Office of Hon. Patrick Withers, Legislator Withers Demands Changes in Religious Land Use Law (Jan. 11, 2007), available at http://www.co. rockland.ny.us/Legislature/LNews/07/01-11-07a.htm [hereinafter Withers].

337. Mamaroneck, supra note 334.

338. Withers, supra note 336. 
"misguided" and has written extensively on its unintended effects. ${ }^{339}$ In the November 2007 elections, RLUIPA was on the minds of a number of candidates running for local office. One newly elected county legislator in Rockland County, New York, stated that when he takes office in January 2008, "his first priority would be to submit a resolution requesting that Congress review the federal Religious Land Use and Institutionalized Persons Act, known as RLUIPA." 340 The same legislator is also talking about "developing a low-cost county loan program" to help municipalities who want to mount a legal defense to challenges based on RLUIPA. ${ }^{341}$ Legislators in Boulder, Colorado sent a resolution to their Congressional representatives seeking RLUIPA's repeal. ${ }^{342}$

While at the grassroots level the impact of RLUIPA on community development, property values, and a "sense of place" continues to generate a significant amount of emotion, it has not seen the same degree of organized opposition as the now infamous Kelo v. City of New Lon$d o n^{343}$ case. This is because the opponents of eminent domain for economic development have the not so secret weapon of a leading national libertarian law firm, the Institute for Justice, funding a country-wide media campaign about the individual and community effects of a legal tool available to government. ${ }^{344}$ When it comes to RLUIPA, however, there is no national organization spearheading an educational and/or advocacy campaign against the negative effects of the statute. There are, however, a number of organizations on the other side, playing a role similar to that of the Institute for Justice on eminent domain issues, advocating for RLUIPA. For example, the Beckett Fund for Religious Liberty blatantly advertises on the front page of its website its interest in litigating RLUIPA cases against local governments, with the following question hot linked to its email: "Is your worship space under attack by

339. See, e.g., Marci Hamilton, California's Defeat of State RLUIPA Bill: The Growing Backlash Against Religious Land Use and Institutionalized Persons Act, FIndLaw, Jan. 29, 2004, http://writ.news.findlaw.com/hamilton/20040129.html (last visited Feb. $25,2008)$.

340. Sarah Netter, Incoming Legislators Have Big Plans for Coming Term, THE JourNal News, Dec. 20, 2007, http://www.thejournalnews.com/apps/pbcs.dll/article ?AID=/20071220/NEWS03/712200412/1026/NEWS10 (last visited Feb. 25, 2008).

341. Id.

342. See Jacob Harkins, Supreme Battle: Boulder County/Church Fight Could Reach Highest Court, The Yellow Scene Magazine (Dec. 2007), http://www.the yellowscene.com/editorials.asp?id=343 (last visited Feb. 25, 2008) (noting that legislators in Boulder, Colorado are facing a RLUIPA challenge from the Rocky Mountain Church who wants to site a large mega-church complex in the county).

343. 545 U.S. 469 (2005).

344. See Castle Coalition: Citizens Fighting Eminent Domain Abuse, http://www. castlecoalition.org/ (last visited Feb. 25, 2008); Institute for Justice: Litigating for Liberty, http://www.ij.org/ (last visited Feb. 25, 2008). 
the zoning board?" 345 In addition, in 2007, the United States Department of Justice launched "The First Freedom Project" to protect religious liberties, including the enforcement of RLUIPA as it pertains to land use actions. ${ }^{346}$ According to a 2006 report from the Department, from 2001-2006 the Department reviewed 118 RLUIPA land use matters, opened twenty-six full-fledged investigations, and touted that sixteen of these investigations resulted in a settlement prior to litigation. ${ }^{347}$

While some still hold out hope that the Supreme Court will find section 2 of RLUIPA unconstitutional, the reality is that municipalities and communities cannot afford to wait for the potential of that day. The $\mathrm{Su}-$ preme Court has already denied certiorari in a number of RLUIPA land use cases, ${ }^{348}$ and as a Boulder County, Colorado, attorney explains, the reach of RLUIPA "will expand to the point where religious institutions are effectively dictating their own land[]use regulations." ${ }^{349}$

To illustrate the impact RLUIPA is having on local governments, a recent search provides the following examples of current battles brewing across America in the news:

- In Litchfield, Connecticut, the historic district commission denied an orthodox Jewish group's (Chabad-Lubavitch) request to turn a Victorian home into a synagogue by adding an additional 20,000 square feet. The proposed new building would contain "a synagogue, indoor pool, and 5000-square foot home for the rabbi and his family, among other things." The commission indicated it would support the project if the group scaled back the proposal to 6,000 square feet.

345. See RLUIPA.com, http://www.rluipa.com (last visited Feb. 25, 2008).

346. See U.S. Dept. of Justice, First Freedom Project, http://www.firstfreedom.gov (last visited Feb. 25, 2008) (announcing that the Department will enforce, among other things, "laws barring zoning authorities from discriminating against houses of worship and religious schools").

347. U.S. Department of Justice, Report on Enforcement of Laws Protecting Religious Freedom: Fiscal Years 2001-2006, available at http://www.firstfreedom.gov/ report/part2.pdf. The report also notes that

[t]he Division has also filed four lawsuits, two of which it won through settlement or consent decree, and two of which are pending. The Division's cases have been quite diverse. They have involved the rights of a Muslim school, two mosques, a Jewish boarding school, several synagogues, a Buddhist temple, a Sikh Gurdwara, and churches and schools of various Christian denominations. The Division has also filed seven friend-of-the court briefs in significant federal appellate cases involving RLUIPA.

Id.

348. See, e.g., Petra Presbyterian Church v. Vill. of Northbrook, 128 S. Ct. 914 (2008); Twp. of Ann Arbor v. DiLaura, 128 S. Ct. 651 (2007); Vision Church v. Vill. of Long Grove, 128 S. Ct. 77 (2007); Town of Surfside v. Midrash Sephardi, Inc., 543 U.S. 1146 (2005); Lighthouse Inst. for Evangelism, Inc. v. City of Long Branch, 543 U.S. 1120 (2005); Civil Liberties for Urban Believers v. City of Chicago, 541 U.S. 1096 (2004).

349. Diana B. Henriques, As Exemptions Grow, Religion Outweighs Regulation, N.Y. Times, Oct. 8, 2006, § 4, at 1, available at http://www.nytimes.com/2006/10/08/ business/08religious.html?_r=1\&oref=slogin. 
The religious group asserts that three other congregations-Episcopalian, Methodist, and Roman Catholic-have structures substantially larger than the building envisioned by its group in the neighborhood. ${ }^{350}$

- A case in Roosevelt, Pennsylvania, is in early litigation stages involving a synagogue which, "due to declining membership, waning participation, and an inability to pay for rabbinical services," entered into a lease agreement with a yeshiva whereby the yeshiva would provide rabbinical services for the congregation in exchange for allowing the use of the synagogue premises for study and worship activities. The township zoning allows for a house of worship, but not for the school, and any expansion of the house of worship requires zoning approvals. During the pendency of the application, the township amended their zoning to specifically allow for this type of use in a different, more rural area of the municipality. ${ }^{351}$

- In Richmond, New Hampshire, the Slaves of the Immaculate Heart of Mary, alleged to be among a number of radical anti-semitic groups, want to expand their building for a school and a chapel. Citing environmental concerns over water and a stressed septic system, along with concerns that the uses do not "legally fit in the neighborhood," the planning board placed thirty conditions on the proposed expansion for it to move forward. The religious group is reportedly going to litigate under RLUIPA. To date, the municipality has spent $\$ 30,000$ in law related fees on this matter, and it is estimated that it might take two years for the parties to get their day in court. ${ }^{352}$

These cases speak to the inherent problems in RLUIPA's structure and operation. Indeed, RLUIPA has had a chilling effect on local government's ability to exercise the police power through zoning to ensure that community character is preserved and that the public health, safety, and welfare is protected. Typical governmental interests such as parking, height, density, setbacks, landscaping, traffic, historic preservation, and impacts on the environment are all taking a back seat to RLUIPA as religious groups are steam-rolling local government officials to grant permit approvals under the threat of litigation. Although the legislative history is clear that RLUIPA does not exempt religious groups from the applicability of zoning and other land use regulations, and while legitimate government concerns may well satisfy the criteria for compelling governmental interests, the reality is that RLUIPA has had the effect of burdening local governments and providing religious groups with an unfair advantage not available to other applicants. The cost to the taxpayers of defending the litigation (with the further penalty of

350. Rinker Buck \& Elizabeth Hamilton, Historic District Rejects Synagogue, HartFord Courant, Dec. 21, 2007, at Al.

351. Jane Meggitt, Litigation Looks into What Defines a House of Worship, EXAMINER, Dec. 20, 2007, http://examiner.gmnews.com/news/2007/1220/Front_Page/016. html (last visited Feb. 29, 2008).

352. Karen Brosz \& Meghan Foley, Town Residents and Express Concern about Catholic Group, ThE Equinox, Dec. 6, 2007, http://media.www.keeneequinox.com/ media/storage/paper537/news/2007/12/06/News/Town-Residents. And.Express.Con cern.About.Catholic.Group-3137245.shtml (last visited Feb. 29, 2008). 
paying legal fees if they lose the litigation), allegations that public officials doing their jobs to enforce comprehensive plan and zoning regulations are somehow acting out of discriminatory motivation, and the public rhetoric that religious groups are launching against governments through their legal teams have all contributed to local governments compromising on the environment and legitimate police power concerns. ${ }^{353}$ RLUIPA has not leveled the playing field for certain groups who might face discrimination, but rather it is has given religious groups almost free reign to control community development in the name of religious exercise. This is certainly a far cry from "smart growth." Discrimination based on religion is illegal and it is unacceptable. Yet, RLUIPA overreaches in its effort to address documented and unfortunate instances of abuse, and the statute has proven to be a nightmare for local government officials and for communities.

\section{Conclusion: Do We Need RLUIPA?}

From what can be gleaned from the legislative history, it seems apparent that Congress was trying to address intentional discrimination caused by abuse in the regulation of land uses. Congress chose to cast a wide net, however, so as to rein in "covert" discrimination that was masquerading in the form of neutral zoning laws. ${ }^{354}$ With the benefit of hindsight, it is now fairly clear that RLUIPA's overinclusiveness has done more harm than good.

\section{A. A "Solution" in Search of a Problem}

To begin with, it is not clear that the type of discrimination sought to be prevented by Congress was especially common. Where is the empirical evidence of discrimination that supports the case for a statute that has, in practice, wrecked havoc on local governments? The recent report from the United States Department of Justice recounts how through nine hearings over three years:

Congress compiled what it termed "massive evidence" of widespread discrimination against religious institutions by state and local officials in land[]use decisions. In particular, Congress found that minority religions are disproportionately disadvantaged in the zoning process. For example, Congress found that while Jews make up only $2 \%$ of the U.S. population, $20 \%$ of recorded cases involved synagogues. Faith groups

353. See Letter from Patrick Withers, County Legislature, District 12, to Eliot Engel, Representative, U.S. House of Representatives (Jan. 10, 2007), available at http://www. co.rockland.ny.us/Legislature/Withers/Religious_Land_Use.htm.

354. See Daniel Lennington, Thou Shalt Not Zone: The Overbroad Applications and Troubling Implications of RLUIPA's Land Use Provisions, 29 SEATTLE U. L. REV. 805, 811 (2006). 
constituting $9 \%$ of the population made up $50 \%$ of reported court cases involving zoning disputes. ${ }^{355}$

However, critics have challenged the legitimacy of the data Congress relied on, suggesting it was merely anecdotal. ${ }^{356}$ To some extent, it seems that the reason more traditional faith groups do not frequently use RLUIPA is that they already have sufficient worship space.

The only independent empirical study to be conducted was reported in a recent note in the Yale Law Journal ${ }^{357}$ and was limited to a review of records from New Haven, Connecticut. The author studied every zoning exemption request filed with the New Haven zoning board of appeals over a nine year period, and concluded that religious institutions, both large and small, face little discernable discrimination from land use regulations, calling into question the wisdom of federal intrusion into the local land use decision making process. ${ }^{358}$ More independent research of this nature is clearly needed. Among the questions that should be asked:

- How many zoning applications are filed on an annual basis by religious organizations?

- What are the categories of requested uses (e.g., houses of worship, schools, housing, camps, etc.)?

- What is the scope of these projects (e.g., in terms of acreage, square footage, size of the congregation - both present and projected) and how does the scope of a project tend relate to the size of the municipality where it is located?

- Are the proposed uses allowed as of right or by special permit in the district?

- Did the municipality engage in meetings and negotiations with the applicant?

- Were multiple applications submitted for the same project?

- Was the application approved or denied?

- If the application was denied, what were the grounds cited?

- If the application was denied, did it result in litigation?

- If the application was approved, was there evidence that the board felt pressured due to RLUIPA?

355. U.S. Dep't of Justice, RePort on Enforcement of LaWs Protecting ReLigious FREEDOM: FISCAL YEARS 2001-2006, 16 (2006), available at http://www.first freedom.gov/report/part2.pdf.

356. See Lennington, supra note 354, at 811-12.

357. Stephen Clowney, An Empirical Look at Churches in the Zoning Process, 116 YALE L.J. 859 (2007).

358. Id. 
- Did the municipality retain special counsel for a potential RLUIPA claim during the zoning review process?

- How much money did the municipality spend as a direct result of RLUIPA on the particular case?

B. Federalism and Local Nature of Zoning

Zoning also has an inherently local nature. Even if traditional rules of federalism may not bar Congress from imposing land use regulations, there are very practical and persuasive reasons why it should not. RLUIPA is a good example. It is important to emphasize, moreover, that prior to RLUIPA, the states were not lacking in statutory religious protections. As the advocate for the state of Ohio explained in City of Boerne, "[i]f you agree with our argument [that RFRA is unconstitutional], I suggest that there will be fifty-one RFRAs when all is said and done. The States are not going to stand idle." ${ }^{359}$ RLUIPA's passage cut off this grassroots approach, even though state level RFRAs have proven to be much more nuanced, flexible, and fair than has the national legislation. The Illinois RFRA, for example, was amended to ensure that it would not interfere with the expansion of Chicago's O'Hare airport. The state weighed its priorities, and determined that the airport, as vital component of the Chicago area and an important asset to the state and its residents, was paramount. ${ }^{360}$ To pass such an exception to RLUIPA would be a difficult task.

Furthermore, it is important to emphasize, that religious institutions were not without constitutional or statutory protections prior to the passage of RFRA and RLUIPA. Intentional discrimination on the basis of religious creed or denomination has never been condoned. The judicial branch has also developed a nuanced and complex body of case law that responded to the need to protect religion while also understanding that religion cannot always be accommodated. This jurisprudence, relying on the religion clauses, the rights to free speech and assembly, and the Equal Protection Clause, could not adequately be replaced by RLUIPA's clunky and ill-defined formulations.

359. Transcript of Oral Arguments, City of Boerne v. Flores, 521 U.S. 507 (1997) (No. 95-2074), available at http://www.oyez.org/cases/1990-1999/1996/1996_95_ 2074/argument/.

360. See St. John's United Church of Christ v. City of Chicago, 502 F.3d 616, 634-35 (7th Cir. 2007). 
Appendix: "Substantial Burden" by Jurisdiction

\begin{tabular}{|c|c|c|}
\hline Jurisdiction & Case & Definition \\
\hline First Circuit & $\begin{array}{l}\text { Mintz v. Roman } \\
\text { Catholic Bishop, } \\
424 \text { F. Supp. 2d 309, } \\
\text { 319-22 (D. Mass. } \\
\text { 2006) }\end{array}$ & $\begin{array}{l}\text { Unclear. The district court explained that } \\
\text { the "'substantial burden' hurdle is high } \\
\text { and ... intensely fact-specific." It cited the } \\
\text { definitions contained in Midrash Sephardi, } \\
\text { Inc., v. Town of Surfside, 366 F.3d } 1214 \\
\text { (11 th Cir. 2006), San Jose Christian } \\
\text { College v. City of Morgan Hill, 360 F.3d } \\
978 \text { (9th Cir. 2004), and Civil Liberties } \\
\text { for Urban Believers v. City of Chicago, } \\
342 \text { F.3d } 752 \text { (7th Cir. 2003), but did not } \\
\text { specifically adopt a particular formulation. }\end{array}$ \\
\hline $\begin{array}{l}\text { Second } \\
\text { Circuit }\end{array}$ & $\begin{array}{l}\text { Westchester Day } \\
\text { Sch. v. Vill. of } \\
\text { Mamaroneck, } 504 \\
\text { F.3d 338, 348-49 } \\
\text { (2d Cir. 2007) }\end{array}$ & $\begin{array}{l}\text { "[A] substantial burden on religious } \\
\text { exercise exists when an individual is } \\
\text { required to 'choose between following } \\
\text { the precepts of her religion and forfeiting } \\
\text { benefits, on the one hand, and abandoning } \\
\text { one of the precepts of her religion ... on } \\
\text { the other hand.' . . But in the context } \\
\text { of land use, a religious institution is not } \\
\text { ordinarily faced with the same dilemma } \\
\text { of choosing between religious precepts } \\
\text { and government benefits. ... Accordingly, } \\
\text { when there has been a denial of a religious } \\
\text { institution's building application, courts } \\
\text { appropriately speak of government } \\
\text { action that directly coerces the religious } \\
\text { institution to change its behavior, rather } \\
\text { than government action that forces the } \\
\text { religious entity to choose between religious } \\
\text { precepts and government benefits." }\end{array}$ \\
\hline Third Circuit & $\begin{array}{l}\text { Lighthouse Inst. } \\
\text { for Evangelism, } \\
\text { Inc. v. City of Long } \\
\text { Branch, } 406 \text { F. Supp. } \\
\text { 2d 507, } 515 \text { (D.N.J. } \\
\text { 2005), aff'd in part, } \\
\text { vacated in part, No. } \\
06-1319,2007 \text { U.S. } \\
\text { App. LEXIS } 27390 \text {, } \\
\text { at *13 (3d Cir. Nov. } \\
27,2007 \text { ) (note that } \\
\text { the resolution of } \\
\text { RLUIPA's } \\
\text { substantial burden } \\
\text { provision was not } \\
\text { appealed) }\end{array}$ & $\begin{array}{l}\text { "[D]emonstrating [a] substantial burden } \\
\text { requires more than a general limitation } \\
\text { on free exercise. Rather, the test requires } \\
\text { a showing that the burden prevents } \\
\text { adherents from conducting or expressing } \\
\text { their religious beliefs or causes them } \\
\text { to forgo religious precepts. . . [A] } \\
\text { substantial burden is one that 'necessarily } \\
\text { bears direct, primary, and fundamental } \\
\text { responsibility for rendering religious } \\
\text { exercise ... effectively impracticable.' } \\
\text { A mere inconvenience is not enough to } \\
\text { meet the 'substantial burden' requirement, } \\
\text { nor is it a substantial burden when } \\
\text { a law merely 'operates so as to make } \\
\text { the practice of religious beliefs more } \\
\text { expansive." }\end{array}$ \\
\hline
\end{tabular}




\section{Appendix: "Substantial Burden" by Jurisdiction (Continued)}

\begin{tabular}{ll}
\hline Jurisdiction & Case \\
\hline & Church of the Hills v. \\
Twp. of Bedminster, & No. 05-3332 (SRC), \\
2006 U.S. Dist. & LEXIS 9488, at \\
& $* 16-17$ (D.N.J. \\
& Feb. 24, 2006) \\
& Albanian Associated \\
& Fund v. Twp. of \\
Wayne, No. 06-cv- \\
3217 (PGS), 2007 \\
U.S. Dist. LEXIS \\
73176, at *27 \\
(D.N. Oct. 1, 2007)
\end{tabular}

(D.N.J. Oct. 1, 2007)

Definition

"While specific definitions may vary, it is well established that a 'substantial burden must place more than an inconvenience on religious exercise,' and must have more of an impact than 'making the practice of [the individual's] religious beliefs more expensive."

The court discussed the substantial burden test adopted by the Third Circuit in Washington v. Klem, 497 F.3d 272 (3d Cir. 2007) (a case challenging a restriction on the number of books inmates could have in their cells as a burden on an inmate's religious exercise) and the standard used in Lighthouse Institute for Evangelism v. City of Long Branch, 100 Fed. App'x 70 (3d Cir. 2004) and then concluded that there was no need to choose either one because " $[w]$ hat is clear ... is that establishing a substantial burden under either standard requires more than merely inhibiting or constraining any religious exercise."

\begin{tabular}{|c|c|}
\hline Fourth Circuit & $\begin{array}{l}\text { Christian Methodist } \\
\text { Episcopal Church v. } \\
\text { Montgomery, } \\
\text { No. 4:04-CV-22322- } \\
\text { RBH, 2007 U.S. Dist. } \\
\text { LEXIS 5133, at } \\
\text { *24-26 (D.S.C. } \\
\text { Jan. 18, 2007) }\end{array}$ \\
\hline
\end{tabular}

"In Civil Liberties for Urban Believers v. City of Chicago, 342 F.3d 752 (7th Cir. 2003), the Seventh Circuit defined 'substantial burden' in the zoning context as 'one that necessarily bears direct, primary, and fundamental responsibility rendering religious exercise-including the use of real property for the purpose thereof within the regulated jurisdiction generallyeffectively impracticable.' . . . The Fourth Circuit has recently defined the term 'substantial burden' under the provisions of RLUIPA dealing with institutionalized persons .... [T] [Te Court found that a substantial burden on religion occurs 'when a state or local government through act or omission put[s] substantial pressure on an adherent to modify his behavior and to violate his beliefs.'"

\begin{tabular}{lll} 
Fifth Circuit & $\begin{array}{l}\text { Castle Hills First } \\
\text { Baptist Church v. } \\
\text { City of Castle Hills, } \\
\text { No. SA-01-CA-1149- }\end{array}$ & $\begin{array}{l}\text { "Regulatory statutes or ordinances that } \\
\text { affect religious activity are constitutional } \\
\text { so long as they impose no undue burden } \\
\text { on the ability of the church or its } \\
\text { members to carry out the observances of }\end{array}$ \\
\hline
\end{tabular}




\begin{tabular}{|c|c|c|}
\hline Jurisdiction & Case & Definition \\
\hline & $\begin{array}{l}\text { LEXIS 4669, at } \\
\text { *30-33 (W.D. } \\
\text { Tex. March 17, } \\
\text { 2004) }\end{array}$ & $\begin{array}{l}\text { their faith.' .. . The Fifth Circuit offered } \\
\text { four other examples of a substantial burden } \\
\text { on religious exercise, three of which are } \\
\text { relevant to the instant inquiry. . . First, a } \\
\text { burden is substantial when the believers } \\
\text { demonstrate that the government's conduct } \\
\text { prevents them 'from engaging in conduct } \\
\text { or having a religious experience which the } \\
\text { faith mandates. This interference must be } \\
\text { more than an inconvenience; the burden } \\
\text { must be substantial and an interference } \\
\text { with a tenet or belief that is central to } \\
\text { religious doctrine.' Second, a burden } \\
\text { exceeds the substantiality threshold when } \\
\text { the government either compels conduct in } \\
\text { contravention of the adherent's beliefs } \\
\text { or requires the adherent to refrain from } \\
\text { conduct that is required by religious } \\
\text { beliefs. Finally, the burden is substantial } \\
\text { 'where the state conditions receipt of an } \\
\text { important benefit upon conduct proscribed } \\
\text { by a religious faith, or where it denies such } \\
\text { a benefit because of conduct mandated by } \\
\text { religious belief, thereby putting substantial } \\
\text { pressure on an adherent to modify his } \\
\text { behavior and to violate his beliefs...." }\end{array}$ \\
\hline xth Circuit & $\begin{array}{l}\text { Living Water Church } \\
\text { of God v. Charter } \\
\text { Twp. of Meridian, } \\
\text { Nos. 05-2309, 06- } \\
1210,2007 \text { U.S. } \\
\text { App. LEXIS } 28825 \text {, } \\
\text { at } * 21-24 \text { (6th Cir. } \\
\text { Dec. } 10,2007 \text { ) }\end{array}$ & $\begin{array}{l}\text { The court noted various formulations given } \\
\text { by the other circuits and then opined that } \\
\text { "[t]hough this circuit has not expressly } \\
\text { defined 'substantial burden,' we have found } \\
\text { that a city's action constituted a substantial } \\
\text { burden in violation of RLUIPA. In DiLaura } \\
v . \text { Township of Ann Arbor, } 112 \text { F. App'x } \\
445 \text { (6th Cir. 2004) ... we concluded that } \\
\text { 'designation as a bed and breakfast would } \\
\text { have effectively barred the plaintiffs } \\
\text { from using the property in the exercise of } \\
\text { their religion and, hence, the defendants' } \\
\text { refusal to allow a variance constituted a } \\
\text { substantial burden on that exercise.' ... If } \\
\text { the term 'substantial burden' is not to be } \\
\text { read out of the statute, RLUIPA cannot } \\
\text { stand for the proposition that a construction } \\
\text { plan is immune from a town's zoning } \\
\text { ordinance simply because the institution } \\
\text { undertaking the construction pursues a } \\
\text { religious mission." }\end{array}$ \\
\hline
\end{tabular}


Appendix: “Substantial Burden" by Jurisdiction (Continued)

\begin{tabular}{|c|c|c|}
\hline Jurisdiction & Case & Definition \\
\hline \multirow[t]{3}{*}{$\begin{array}{l}\text { Seventh } \\
\text { Circuit }\end{array}$} & $\begin{array}{l}\text { Civil Liberties for } \\
\text { Urban Believers v. } \\
\text { City of Chic., } 342 \\
\text { F.3d 752, 761 } \\
\text { (7th Cir. 2003) } \\
\text { [hereinafter } \\
\text { C.L.U.B.] }\end{array}$ & $\begin{array}{l}\text { "[I]n the context of RLUIPA's broad } \\
\text { definition of religious exercise, a land- } \\
\text { use regulation that imposes a substantial } \\
\text { burden on religious exercise is one that } \\
\text { necessarily bears direct, primary, } \\
\text { and fundamental responsibility for } \\
\text { rendering religious exercise-including } \\
\text { the use of real property for the purpose } \\
\text { thereof within the regulated jurisdiction } \\
\text { generally-effectively impracticable." }\end{array}$ \\
\hline & $\begin{array}{l}\text { Sts. Constantine \& } \\
\text { Helen Greek } \\
\text { Orthodox Church, } \\
\text { Inc. v. City of New } \\
\text { Berlin, 396 F.3d } 895 \text {, } \\
900 \text { (7th Cir. 2005) } \\
\text { [hereinafter New } \\
\text { Berlin] }\end{array}$ & $\begin{array}{l}\text { In this case, the Seventh Circuit seemed } \\
\text { to repudiate the conception of "substantial } \\
\text { burden" previously set forth in C.L.U.B. } \\
\text { Whereas the prior case seemed to indicate } \\
\text { that expense or inconvenience would } \\
\text { not amount to a substantial burden, the } \\
\text { court held in New Berlin that a substantial } \\
\text { burden was shown where the religious } \\
\text { organization would "either [have] to sell } \\
\text { the land that it bought in New Berlin and } \\
\text { find a suitable alternative parcel or be } \\
\text { subjected to unreasonable delay by having } \\
\text { to restart the permit process to satisfy the } \\
\text { Planning Commission about a contingency } \\
\text { for which the Church has already provided } \\
\text { complete satisfaction." }\end{array}$ \\
\hline & $\begin{array}{l}\text { Vision Church v. } \\
\text { Vill. of Long Grove, } \\
468 \text { F.3d } 975,997 \\
\text { (7th Cir. 2006) }\end{array}$ & $\begin{array}{l}\text { The Seventh Circuit reaffirmed its C.L.U.B. } \\
\text { substantial burden test in this case, making } \\
\text { it clear that New Berlin did not modify the } \\
\text { standard. As the court stated: "we have } \\
\text { held that a land use regulation imposes a } \\
\text { 'substantial burden' on religious exercise } \\
\text { if it 'necessarily bears direct, primary, } \\
\text { and fundamental responsibility for } \\
\text { rendering religious exercise-including } \\
\text { the use of real property for the purpose } \\
\text { thereof within the regulated jurisdiction } \\
\text { generally- effectively impracticable.' } \\
\text { Similarly, interpreting the First } \\
\text { Amendment, the Supreme Court has found } \\
\text { a 'substantial burden' to exist when the } \\
\text { government put 'substantial pressure on } \\
\text { an adherent to modify his behavior and } \\
\text { to violate his beliefs.'" }\end{array}$ \\
\hline
\end{tabular}




\begin{tabular}{|c|c|c|}
\hline Jurisdiction & Case & Definition \\
\hline & $\begin{array}{l}\text { Petra Presbyterian } \\
\text { Church v. Vill. of } \\
\text { Northbrook, } 489 \\
\text { F.3d 846, 851 } \\
\text { (7th Cir. 2007) }\end{array}$ & $\begin{array}{l}\text { In Petra, the Seventh Circuit again refined } \\
\text { its substantial burden analysis, this time } \\
\text { shedding light on New Berlin: "As we } \\
\text { explained in Sts. Constantine \& Helen } \\
\text { Greek Orthodox Church, Inc. v. City of } \\
\text { New Berlin, } 396 \mathrm{~F} \text {. 3d } 895,900 \text { (7th Cir. } \\
2005 \text { ),... once the organization has } \\
\text { bought property reasonably expecting } \\
\text { to obtain a permit, the denial of the } \\
\text { permit may inflict a hardship on it. In } \\
\text { [New Berlin] the denial was so utterly } \\
\text { groundless as to create an inference of } \\
\text { religious discrimination, so that the case } \\
\text { could equally have been decided under } \\
\text { the 'less than equal terms' provision } \\
\text { of RLUIPA, which does not require a } \\
\text { showing of substantial burden. But Petra } \\
\text { had no reasonable expectation of obtaining } \\
\text { a permit [to build a church in an industrial } \\
\text { zone]. Having decided to go ahead and } \\
\text { purchase the property outright after it } \\
\text { knew that the permit would be denied, } \\
\text { Petra assumed the risk of having to sell the } \\
\text { property and find an alternative site for its } \\
\text { church should the denial be upheld (or, if } \\
\text { illegal, legally reimposed), just like any } \\
\text { other religious organization that wanted to } \\
\text { build in the industrial zone." }\end{array}$ \\
\hline
\end{tabular}

\begin{tabular}{|c|c|c|}
\hline \multirow[t]{2}{*}{ Ninth Circuit } & $\begin{array}{l}\text { Guru Nanak Sikh } \\
\text { Soc'y of Yuba } \\
\text { City v. County of } \\
\text { Sutter, } 456 \text { F.3d } 978 \text {, } \\
988 \text { (9th Cir. 2006) }\end{array}$ & $\begin{array}{l}\text { "[A] 'substantial burden' must place } \\
\text { more than an inconvenience on religious } \\
\text { exercise ... . Accordingly, interpreting } \\
\text { RLUIPA, this court has held: '[F]or a land } \\
\text { use regulation to impose a 'substantial } \\
\text { burden,' it must be 'oppressive' to a } \\
\text { 'significantly great' extent. That is, } \\
\text { a 'substantial burden' on 'religious } \\
\text { exercise' must impose a significantly great } \\
\text { restriction or onus upon such exercise.'" }\end{array}$ \\
\hline & $\begin{array}{l}\text { San Jose Christian } \\
\text { Coll. v. City of } \\
\text { Morgan Hill, } 360 \\
\text { F.3d } 1024,1034 \\
\text { (9th Cir. 2004) }\end{array}$ & $\begin{array}{l}\text { "[F]or a land use regulation to impose a } \\
\text { 'substantial burden,' it must be 'oppressive' } \\
\text { to a 'significantly great' extent. That } \\
\text { is, a 'substantial burden' on 'religious } \\
\text { exercise' must impose a significantly great } \\
\text { restriction or onus upon such exercise." }\end{array}$ \\
\hline
\end{tabular}




\section{Appendix: "Substantial Burden" by Jurisdiction (Continued)}

\begin{tabular}{lll}
\hline Jurisdiction & Case & Definition \\
\hline Tenth Circuit & $\begin{array}{l}\text { Grace United } \\
\text { Methodist Church v. } \\
\text { City of Cheyenne, } \\
\text { 451 F.3d 643, 661-62 } \\
\text { (10th Cir. 2006) }\end{array}$ & $\begin{array}{l}\text { "Concerning the definition of } \\
\text { substantial burden, we noted that Lyng v. } \\
\text { [Northwestern] Indian Cemetery } \\
\text { (1988) was controlling. The Supreme } \\
\text { Court stated there that the incidental effects } \\
\text { of otherwise lawful government programs } \\
\text { 'which may make it more difficult to } \\
\text { practice certain religions but which have } \\
\text { no tendency to coerce individuals into } \\
\text { acting contrary to their religious beliefs' } \\
\text { do not constitute substantial burdens on the } \\
\text { exercise of religion." }\end{array}$ \\
\hline
\end{tabular}

$\begin{array}{ll}\text { Eleventh } & \text { Midrash Sephardi, } \\ \text { Circuit } & \text { Inc. v. Town of } \\ & \text { Surfside, 366 F.3d } \\ & \text { 1214, 1227 (11th } \\ & \text { Cir. 2004) }\end{array}$

“[A] 'substantial burden' must place more than an inconvenience on religious exercise; a 'substantial burden' is akin to significant pressure which directly coerces the religious adherent to conform his or her behavior accordingly. Thus, a substantial burden can result from pressure that tends to force adherents to forego religious precepts or from pressure that mandates religious conduct."

Konikov v. Orange County, 410 F.3d 1317,1323 (11th Cir. 2005)

Connecticut
Cambodian Buddhist Soc'y v. Planning and Zoning Comm'n of Newtown, No. CV030350572S, 2005 Conn. Super. LEXIS 3158 (Conn. Super. Ct. Nov. 18, 2005), aff'd on other grounds, No. SC 17690, 2008 Conn. LEXIS 41 (Conn. Feb. 12, 2008)
In Konikov, the Eleventh Circuit reaffirmed the definition of substantial burden given in Midrash Sephardi, Inc., v. Town of Surfside, 366 F.3d 1214 (11th Cir. 2006).

Unclear. The court referred to the tests of the Seventh, Ninth, and Eleventh Circuits. It then proceeded to describe Connecticut case law: "our Appellate Court ... stated that "churches and religious organizations can be regulated under a state's police power if that regulation is religiously neutral and for secular purposes .... The [F]irst [A]mendment cannot be extended to such an extent that a claim of exemption from the laws based on religious freedom can be extended to avoid otherwise reasonable and neutral legal obligations imposed by government .... 'Secular concerns such as safety do not impinge on the exercise of religion, assuming, of course, that the recitation of such concerns is not a mere pretext. Our case law already establishes a heightened scrutiny as to 


\section{Appendix: "Substantial Burden" by Jurisdiction (Continued)}

\begin{tabular}{|c|c|c|}
\hline Jurisdiction & Case & Definition \\
\hline & & $\begin{array}{l}\text { the more general and less quantitative } \\
\text { considerations. The statutes seeking to } \\
\text { preserve the value of freedom of religion } \\
\text { can peacefully coexist with zoning } \\
\text { regulations regarding safety, traffic, and the } \\
\text { like, so long as those concerns are not used } \\
\text { to mask discriminatory intent." }\end{array}$ \\
\hline Michigan & $\begin{array}{l}\text { Greater Bible Way } \\
\text { Temple of Jackson } \\
\text { City v. City of } \\
\text { Jackson, } 733 \text { N.W.2d } \\
734,750, \\
750 \text { n.23 (2007). }\end{array}$ & $\begin{array}{l}\text { The court noted that it found the definitions } \\
\text { of substantial burden contained in C.L. U.B. v. } \\
\text { City of Chicago, } 342 \text { F.3d } 752 \text { (7th Cir. } \\
\text { 2003), San Jose Christian College v. City } \\
\text { of Morgan Hill, } 360 \text { F.3d } 978 \text { (9th Cir. } \\
\text { 2004), Midrash Sephardi, Inc. v. Town of } \\
\text { Surfside, } 366 \text { F.3d } 1214 \text { (11th Cir. 2006) } \\
\text { and Grace United Methodist Church v. City } \\
\text { of Cheyenne, } 451 \text { F.3d } 643 \text { (10th Cir. 2006) } \\
\text { to be persuasive. It cited several RLUIPA } \\
\text { prisoner cases as well, and then synthesized } \\
\text { the following definition: "a 'substantial } \\
\text { burden' on one's 'religious exercise' } \\
\text { exists where there is governmental action } \\
\text { that coerces one into acting contrary to } \\
\text { one's religious beliefs by way of doing } \\
\text { something that one's religion prohibits or } \\
\text { refraining from doing something that one's } \\
\text { religion requires. That is, a 'substantial } \\
\text { burden' exists when one is forced to choose } \\
\text { between violating a law (or forfeiting an } \\
\text { important benefit) and violating one's } \\
\text { religious tenets. A mere inconvenience } \\
\text { or irritation does not constitute a } \\
\text { 'substantial burden.' Similarly, something } \\
\text { that simply makes it more difficult in some } \\
\text { respect to practice one's religion does not } \\
\text { constitute a 'substantial burden.' Rather, } \\
\text { a 'substantial burden' is something that } \\
\text { 'coerce[s] individuals into acting contrary } \\
\text { to their religious beliefs . ..." In a } \\
\text { footnote, the court added: "[w]e recognize } \\
\text { that some courts have held that a 'substantial } \\
\text { burden' exists where there is 'delay, } \\
\text { uncertainty, and expense.' However, we } \\
\text { reject this definition of 'substantial burden' } \\
\text { both because it is inconsistent with the } \\
\text { United States Supreme Court's definition } \\
\text { of the phrase and because it is inconsistent } \\
\text { with the common understanding of the } \\
\text { phrase 'substantial burden.'” }\end{array}$ \\
\hline
\end{tabular}




\begin{tabular}{|c|c|c|}
\hline Jurisdiction & Case & Definition \\
\hline New Jersey & $\begin{array}{l}\text { House of Fire } \\
\text { Christian Church v. } \\
\text { Zoning Bd. of } \\
\text { Adjustment of City } \\
\text { of Clifton, } 879 \text { A.2d } \\
1212,1225 \text { (N.J. } \\
\text { Super. Ct. App. } \\
\text { Div. 2005) }\end{array}$ & $\begin{array}{l}\text { The court seemed to adopt the Eleventh } \\
\text { Circuit's test in Midrash Sephardi, Inc. v. } \\
\text { Town of Surfside, } 366 \text { F.3d } 1214 \text { (11th } \\
\text { Cir. 2006): "[A] 'substantial burden' must } \\
\text { place more than an inconvenience on } \\
\text { religious exercise; a 'substantial burden' } \\
\text { is akin to significant pressure which } \\
\text { directly coerces the religious adherent to } \\
\text { conform his or her behavior accordingly. } \\
\text { Thus, a substantial burden can result from } \\
\text { pressure that tends to force adherents } \\
\text { to forego religious precepts or from } \\
\text { pressure that mandates religious } \\
\text { conduct." }\end{array}$ \\
\hline
\end{tabular}

\begin{tabular}{|c|c|c|}
\hline Oregon & $\begin{array}{l}\text { Corp. of the } \\
\text { Presiding Bishop v. } \\
\text { City of W. Linn, } \\
111 \text { P.3d } 1123 \text {, } \\
1129-30 \text { (Or. 2005) }\end{array}$ & $\begin{array}{l}\text { The court noted as persuasive the tests } \\
\text { adopted in Westchester Day School v. } \\
\text { Village of Mamaroneck, } 386 \text { F.3d } 183 \text { ( } 2 \mathrm{~d} \\
\text { Cir. 2004), San Jose Christian College v. } \\
\text { City of Morgan Hill, } 360 \text { F.3d } 978 \text { (9th Cir. } \\
\text { 2004), and Midrash Sephardi, Inc. v. Town } \\
\text { of Surfside, } 366 \text { F.3d } 1214 \text { (11th Cir. 2006). } \\
\text { The court then explained: "We agree } \\
\text { with the reasoning of the cases discussed } \\
\text { above, and, on that basis, we conclude } \\
\text { that a government regulation imposes a } \\
\text { substantial burden on religious exercise } \\
\text { only if it 'pressures' or 'forces' a choice } \\
\text { between following religious precepts } \\
\text { and forfeiting certain benefits, on the } \\
\text { one hand, and abandoning one or more } \\
\text { of those precepts in order to obtain the } \\
\text { benefits, on the other." }\end{array}$ \\
\hline
\end{tabular}

Pennsylvania Ridley Park United Methodist Church v. Zoning Hearing Bd., 920 A.2d 953, 961 n. 15 (Pa. Commw. Ct. 2007)
"To meet the substantial burden prong of the RLUIPA, a person must demonstrate that the land-use regulation actually imposed a substantial burden on religious exercise. It requires a showing that the burden prevents adherents from conducting or expressing their religious beliefs or causes them to forgo religious precepts. A substantial burden is one that 'necessarily bears direct, primary, and fundamental responsibility for rendering religious exercise effectively impracticable.' A mere inconvenience is not enough to meet the substantial burden requirement." 


\begin{tabular}{|c|c|c|}
\hline Jurisdiction & Case & Definition \\
\hline & $\begin{array}{l}\text { City of Hope v. } \\
\text { Sadsbury Twp. } \\
\text { Zoning Hearing } \\
\text { Board, } 890 \text { A.2d } \\
1137,1149 \text { (Pa. } \\
\text { Commw. Ct. 2006) }\end{array}$ & $\begin{array}{l}\text { "The substantial burden proscribed by } \\
\text { RLUIPA is the same as that articulated in } \\
\text { free exercise jurisprudence and includes: } \\
\text { 'foregoing or modifying the practice of } \\
\text { one's religion because of governmental } \\
\text { interference.' It has been recognized that } \\
\text { a substantial burden pursuant to RLUIPA } \\
\text { must constitute more than a mere } \\
\text { inconvenience or incidental effect on the } \\
\text { free exercise of a religious practice." }\end{array}$ \\
\hline
\end{tabular}


HeinOnline -- 40 Urb. Law. 2682008 